Aus der Abteilung Humangenetik

(Prof. Dr. med. Dr. h. c. W. Engel)

im Zentrum Hygiene und Humangenetik

der Medizinischen Fakultät der Universität Göttingen

\title{
Molekulare Charakterisierung des COPS5-Gens und seines Genproduktes als Kandidat für die Spastische Spinalparalyse
}

\author{
INAUGURAL - DISSERTATION \\ zur Erlangung des Doktorgrades \\ der Medizinischen Fakultät \\ der Georg-August-Universität zu Göttingen
}

vorgelegt von

André Eisenberg

aus

Hildesheim

Göttingen 2009 
D e k a n: Prof. Dr. med. C. Frömmel

I. Berichterstatter: PD Dr. rer. nat. J. Neesen

II. Berichterstatter: Prof. Dr. med. Wilichowski

Tag der mündlichen Prüfung: 07.03.2011 



\section{INHALTSVERZEICHNIS}

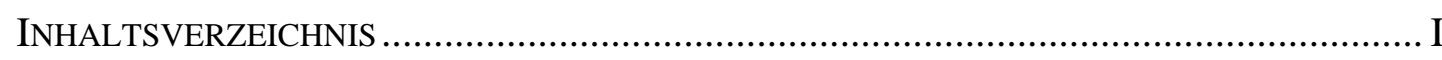

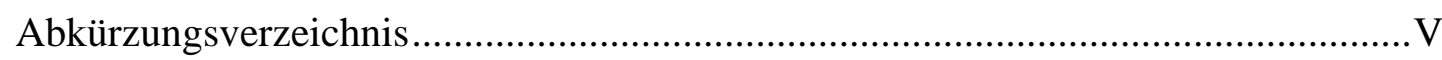

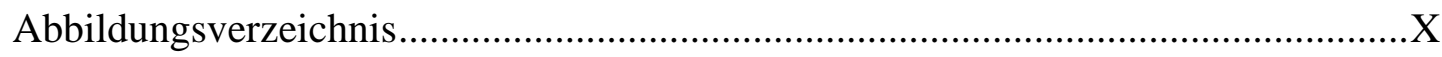

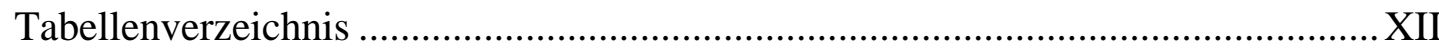

1 EINLEITUNG 1

$1.1 \quad$ Hereditäre Spastische Paraplegien ..............................................................

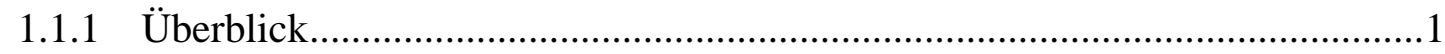

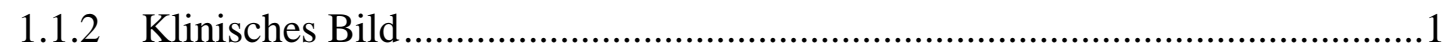

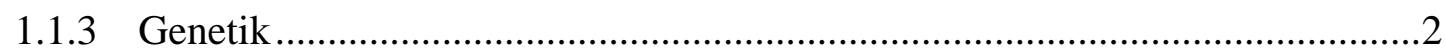

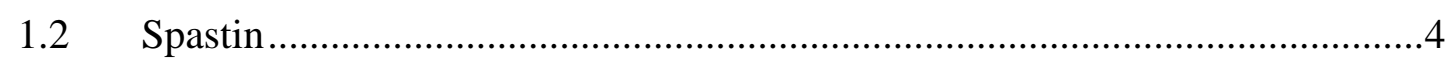

1.3 Mutationen in putativen Interaktionspartnern des Spastins als Ursache

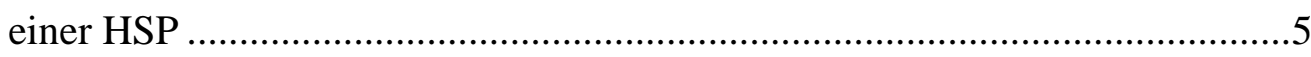

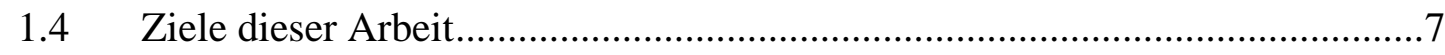

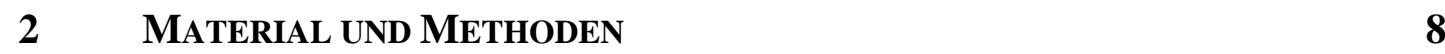

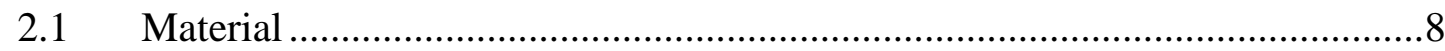

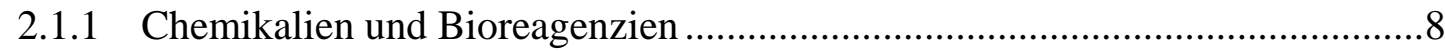

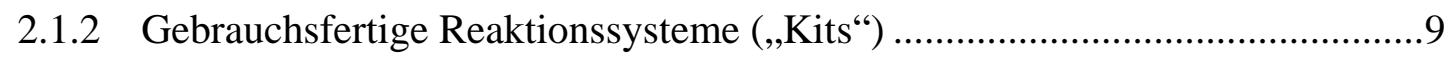

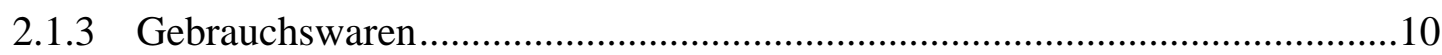

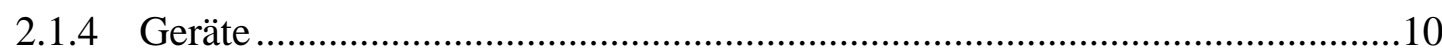

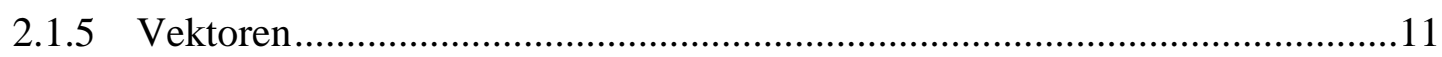

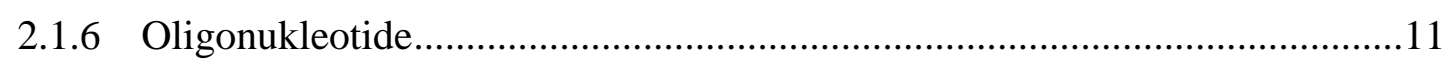

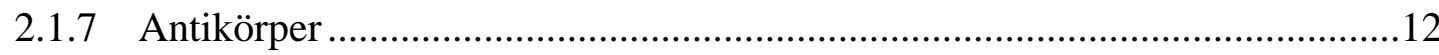

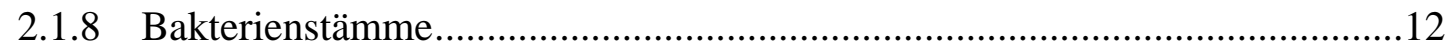

2.1.9 Bakterienkulturmedien und LB-Platten .......................................................13

2.1.9.1 Bakterienkulturmedien ..................................................................13

2.1.9.2 LB-Platten ................................................................................ 13

2.1.10 Zelllinien und Zellkulturmedien ................................................................13

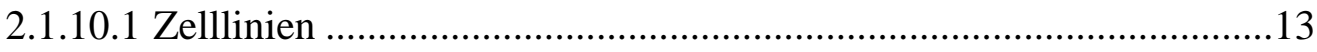

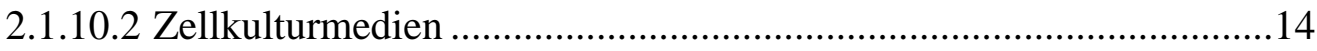

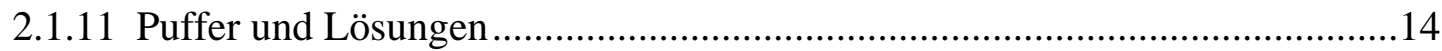

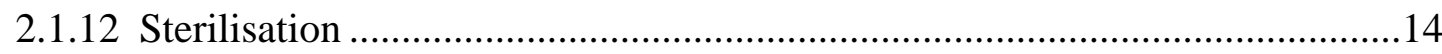

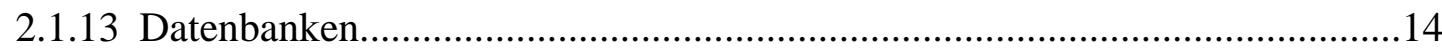




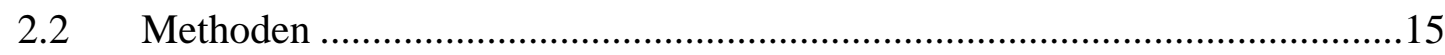

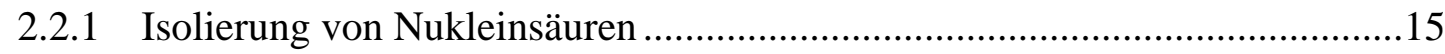

2.2.1.1 Isolierung von Plasmid-DNA im analytischen Maßstab..................15

2.2.1.2 Isolierung von Plasmid-DNA im präparativen Maßstab...................16

2.2.1.3 Endotoxin-freie Isolierung von Plasmid-DNA................................17

2.2.1.4 Herstellung von Bakterien-Glycerinstocks ......................................18

2.2.1.5 Konzentrationsbestimmung von Nukleinsäuren .............................18

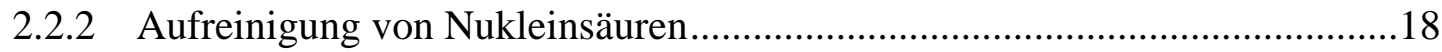

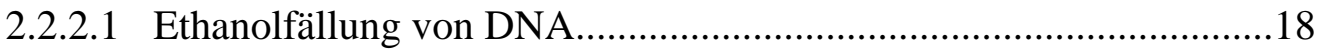

2.2.2.2 Aufreinigung von PCR-Produkten über Microcon-PCR-Säulen ......19

2.2.2.3 Aufreinigung von DNA-Fragmenten aus Agarosegelen ...................19

2.2.3 Enzymatische Modifikation von Nukleinsäuren...........................................20

2.2.3.1 Analytische Restriktion ................................................................20

2.2.3.2 Ligation von DNA-Fragmenten ..................................................21

2.2.3.3 TA-Klonierung mit dem pGEM-T-Easy-Vektor-System..................21

2.2.4 Transformation kompetenter Zellen mit Plasmid-DNA ...............................22

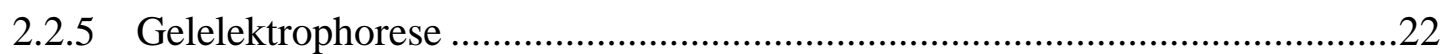

2.2.5.1 Analytische Gelelektrophorese.....................................................22

2.2.5.2 Präparative Gelelektrophorese ....................................................23

2.2.6 Polymerase-Kettenreaktion (PCR) ..............................................................24

2.2.6.1 PCR an humaner genomischer DNA............................................24

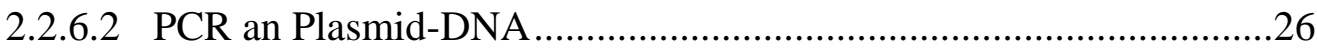

2.2.6.3 Reverse-Transkriptase-PCR (RT-PCR) .........................................27

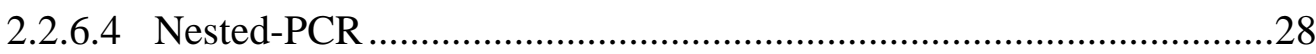

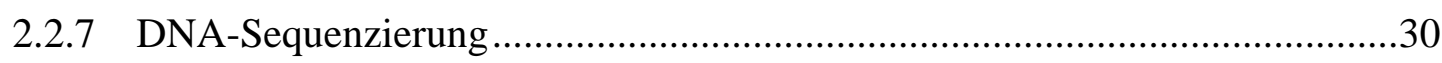

2.2.8 Transfer bakterieller Nukleinsäuren auf Nylonfilter.....................................31

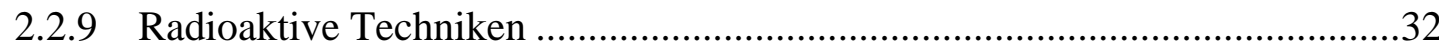

2.2.9.1 Radioaktive Markierung von Nukleinsäuren ...................................32

2.2.9.2 Hybridisierung radioaktiv markierter Sonden .................................32

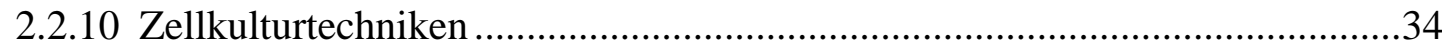

2.2.10.1 Kultivierung von NIH3T3-Zellen ....................................................34

2.2.10.2 Transfektion von NIH3T3-Zellen ...................................................34

2.2.10.3 Isolierung von Zellkultur-Proteinen .............................................35

2.2.11 Analyse von Fluoreszenzproteinen ................................................................36 
2.2.12 Immunfluoreszenzfärbung von NIH3T3-Zellen ........................................36

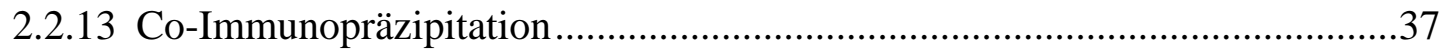

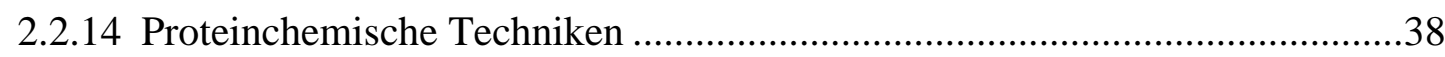

2.2.14.1 SDS-Polyacrylamidgelelektrophorese (SDS-PAGE)......................38

2.2.14.2 Western-Blot (Semi-dry Blot) .....................................................39

2.2.14.3 Immunologische Detektion membrangebundener Proteine ..............40

$3 \quad$ ERGEBNISSE $\quad 42$

3.1 Expressionsanalyse von Cops5 in der Maus durch RT-PCR .........................42

3.2 Charakterisierung von Cops5 als Interaktionspartner des Spastins in NIH3T3-Zellen.

3.2.1 Synthese der kodierenden Sequenz von Cops5 und Klonierung in den pGEM-T-Easy-Vektor

3.2.2 Generierung von Cops5-Konstrukten mithilfe bakterieller

Expressionssysteme

3.2.2.1 Klonierung von Cops5 aus pGEM-T-Easy in pQM-NTag/A-

Intron

3.2.2.2 Klonierung von Cops5 aus pGEM-T-Easy in pEGFP-C1.................48

3.2.2.3 Klonierung von COPS5 aus pGEM-T-Easy in pDsRed2-N1 ...........50

3.2.3 Generierung von Spastin-Konstrukten mithilfe bakterieller

Expressionssysteme .52

3.2.4 Subzelluläre Lokalisation des Cops5-Proteins in NIH3T3-Zellen mittels direkter Fluoreszenzanalyse

3.2.5 Subzelluläre Lokalisation des Spastin-Proteins in NIH3T3-Zellen mittels immunzytochemischer Fluoreszenzanalyse ..............................................54

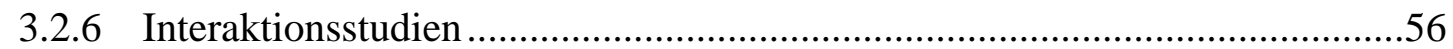

3.2.6.1 Co-Lokalisation von Cops5 und Spastin in NIH3T3-Zellen mittels direkter und immunzytochemischer Fluoreszenzanalyse ......56

3.2.6.2 Co-Immunopräzipitation von Cops5 und Spastin nach Isolierung

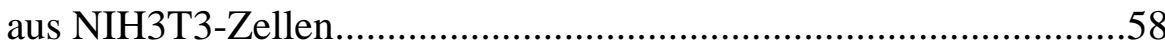

3.3 Sequenzierung des COPS5-Gens von Patienten mit klinisch diagnostizierter HSP

3.3.1 Identifizierung der Exon/Intron-Übergänge und Amplifizierung der Exons von COPS5

3.3.2 Veränderungen der COPS5-Sequenz auf DNA-Ebene 
$4 \quad$ DISKUSSION

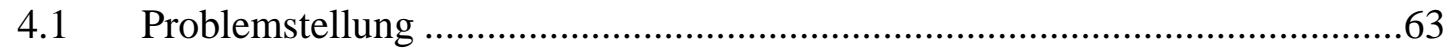

4.2 COPS5 als Interaktionspartner des Spastins ..............................................64

4.2.1 Struktur, Isoformen und subzelluläre Lokalisation von Spastin .....................64

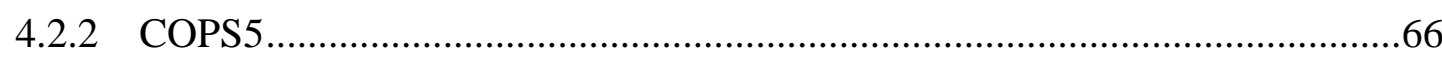

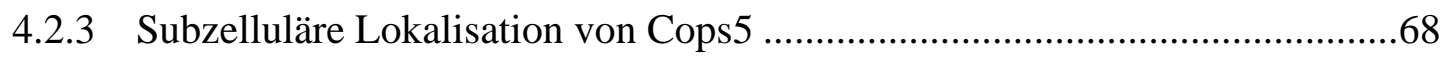

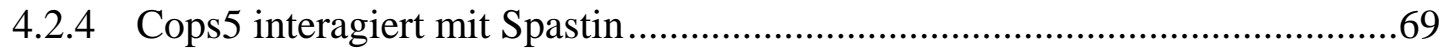

4.2.5 Physiologische Relevanz der COPS5 - Spastin Interaktion............................69

4.3 DNA-Analyse von Patienten mit klinisch diagnostizierter HSP ....................72

5 ZUSAMMENFASSUNG

6 ANHANG $\quad 76$

6.1 Spastin (Homo sapiens) - Kodierende Sequenz für die Isoform II ................76

6.2 Spastin (Homo sapiens) - Aminosäuresequenz für die Isoform II .................78

6.3 COPS5 (Homo sapiens) - Kodierende Sequenz ...........................................79

6.4 Cops5 (Mus musculus) - Kodierende Sequenz ............................................80

6.5 COPS5 (Homo sapiens) - Aminosäuresequenz...........................................81

6.6 Cops5 (Mus musculus) - Aminosäuresequenz ............................................81

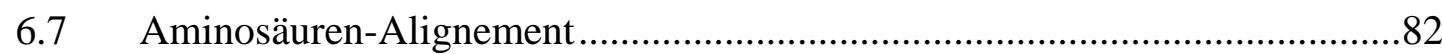

$\begin{array}{lll}7 & \text { LITERATURVERZEICHNIS } & 83\end{array}$ 


\section{Abkürzungsverzeichnis}

\begin{tabular}{|c|c|}
\hline$\alpha$ & Alpha \\
\hline AAA & ATPase associated with diverse cellular activity \\
\hline Abb. & Abbildung \\
\hline ARHSP & autosomal-rezessive HSP \\
\hline ATP & Adenosintriphosphat \\
\hline BCIP & 5-Brom-4-Chlor-3Indoylphosphat \\
\hline BLAST & engl.: basic local alignment serch tool \\
\hline bp & Basenpaare \\
\hline BSA & Rinderserumalbumin \\
\hline bzw. & beziehungsweise \\
\hline${ }^{\circ} \mathrm{C}$ & Grad Celsius \\
\hline ca. & circa \\
\hline cDNA & komplementäre DNA \\
\hline cM & centiMorgan \\
\hline $\mathrm{cm}^{2}$ & Quadratzentimeter \\
\hline CMV & Zytomegalievirus \\
\hline $\mathrm{CO}_{2}$ & Kohlendioxid \\
\hline COPS5 & homo sapiens cop9 constitutive morphogenic homolog subunit 5 \\
\hline CSN & COP9 Signalosome \\
\hline CSN5 & COP9 Signalosome Subunit 5 \\
\hline Су3 & 5,5’-disulfo-1,1’di(-carbopentenyl)-3,3,3’,3’- \\
\hline & Tetramethylinolocarbocyanin (cyanin Сy3.18) \\
\hline $\mathrm{Da}$ & Dalton \\
\hline DAPI & 4',6-Diamidino-2-phenylindol-Dihydrochlorid \\
\hline dATP & Desoxyadenosintriphosphat \\
\hline dCTP & Desoxycytosintriphosphat \\
\hline ddNTP & Didesoxynukleosidtriphosphat \\
\hline DEPC & Diethylpyrocarbonat \\
\hline dGTP & Desoxyguanosintriphosphat \\
\hline $\mathrm{dH}_{2} \mathrm{O}$ & deionisiertes Wasser \\
\hline DMEM & Dulbecco’s Modified Eagle Medium \\
\hline DMP & Dimethylpimelimidatdihydrochlorid \\
\hline
\end{tabular}




\begin{tabular}{|c|c|}
\hline DMSO & Dimethylsulfid \\
\hline DNA & Desoxyribonukleinsäure \\
\hline dNTP & Desoxynukleosidtriphosphat \\
\hline DTT & Dithiothreitol \\
\hline dTTP & Desoxythymidintriphosphat \\
\hline$\varepsilon$ & Epsilon \\
\hline E. coli & Escherichia coli \\
\hline EDTA & Ethylen-di-amin-tetraessigsäure \\
\hline EGFP & GFP-Molekül mit den Mutationen F64L und S65T für verbesserte \\
\hline & Fluoreszenz-Eigenschaften (Cormack et al., 1996) \\
\hline et al. & et alii (und andere) \\
\hline FITC & Fluoreszeinthiocyanat \\
\hline FKS & Fetales Kälberserum \\
\hline g & Gramm, Erdbeschleunigung $\left(1 \mathrm{x} g=9.81 \mathrm{~m} / \mathrm{s}^{2}\right)$ \\
\hline GAPDH & Glycerinaldehyd-3-phosphat-Dehydrogenase \\
\hline GFP & grün fluoreszierendes Protein \\
\hline h & Stunde \\
\hline HSP & Hereditäre Spastische Paraplegie \\
\hline IgG & Immunglobulin G \\
\hline IPTG & Isopropyl-b-thiogalactopyranosid \\
\hline JAB1 & Jun Activation Domain-Binding Protein 1 \\
\hline JAMM & Jab1/MPN domain metalloenzyme \\
\hline $\mathrm{kb}$ & Kilobasenpaare \\
\hline $\mathrm{kDa}$ & Kilodalton \\
\hline LB & Luria Bertani \\
\hline$\mu$ & $\operatorname{mikro}=10^{-6}$ \\
\hline$\mu g$ & Mikrogramm \\
\hline$\mu l$ & Mikroliter \\
\hline$\mu \mathrm{M}$ & Mikromol \\
\hline $\mathrm{m}$ & milli $=10^{-3}$ \\
\hline M & Molar \\
\hline $\mathrm{mA}$ & Milliampère \\
\hline MCS & engl.: multiple cloning site (Polylinker) \\
\hline $\mathrm{mg}$ & Milligramm \\
\hline
\end{tabular}




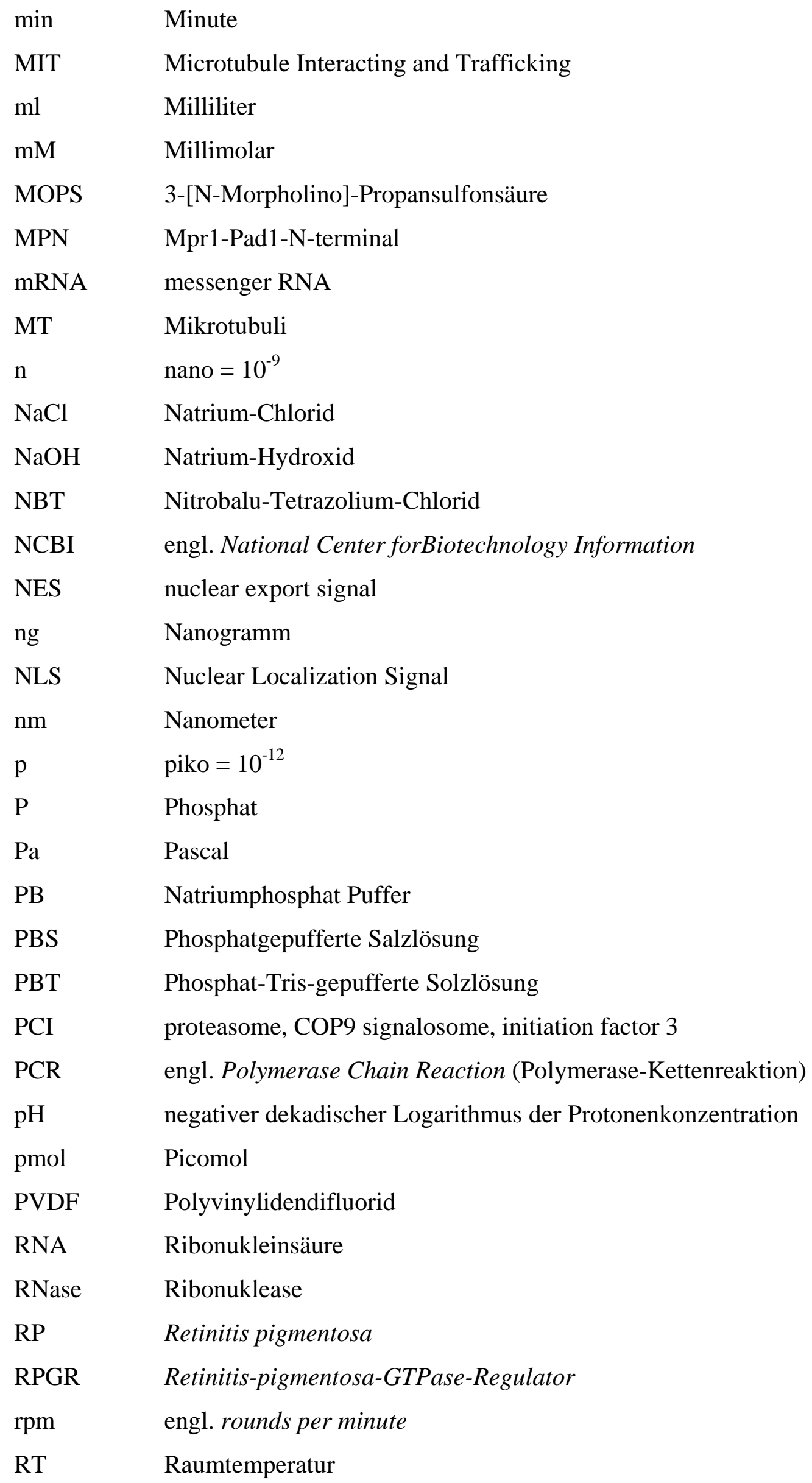


RT-PCR Reverse-Transkriptase-Polymerase-Kettenreaktion

SDS-PAGE Sodiumdodecylsulfat-Polyacrylamidgelelektrophorese

SPG Spastische Paraplegie

SSC standard saline citrat

Tab. Tabelle

Taq Thermus aquaticus

TM Transmembrandomäne

Tris Trishydroxymethylaminomethan

TRITC Tetramethyl-Rhodamin-Iso-Thiocyanat

U engl. Unit = definierte Enzymeinheit

UTR untranslatierte Region

UV ultraviolettes Licht

V Volt

v/v Volumen pro Volumen

w/v Gewicht pro Volumen

X Mal

X-Gal 5-Brom-4-4Chlor-3-Indoyl- $\beta$-D-Galaktopyranosid

Y2H Yeast-two-Hybrid 


\section{Symbole für Aminosäuren}

$\begin{array}{lll}\text { A } & - & \text { Alanin } \\ \text { C } & - & \text { Cystein } \\ \text { D } & - & \text { Asparaginsäure } \\ \text { E } & - & \text { Glutaminsäure } \\ \text { F } & - & \text { Phenylalanin } \\ \text { G } & - & \text { Glycin } \\ \text { H } & - & \text { Histidin } \\ \text { I } & - & \text { Isoleucin } \\ \text { K } & - & \text { Lysin } \\ \text { L } & - & \text { Leucin } \\ \text { M } & - & \text { Methionin } \\ \text { N } & - & \text { Asparagin } \\ \text { P } & - & \text { Prolin } \\ \text { Q } & - & \text { Glutamin } \\ \text { R } & - & \text { Arginin } \\ \text { S } & - & \text { Serin } \\ \text { T } & - & \text { Threonin } \\ \text { V } & - & \text { Valin } \\ \text { W } & - & \text { Tryptophan } \\ \text { Y } & - & \text { Tyrosin } \\ & & \end{array}$

\section{Symbole für Nukleinsäuren}
A - $\quad$ Adenin
C - Cytosin
G - - Guanin
$\mathrm{T} \quad$ - $\quad$ Thymin
U $\quad$ - Uracil 


\section{Abbildungsverzeichnis}

Abbildung 3.1: $\quad$ Schematische Darstellung der murinen Cops5-Exonstruktur

Seite 42

Abbildung 3.2: RT-PCR-Produkt von Cops5 in murinen Organen und embryonalem Gewebe aufgetrennt in 0,8 \%igen Agarosegel

Seite 43

Abbildung 3.3: Schematische Darstellung der 1084 bp großen kodierenden Sequenz von Cops5

Seite 45

Abbildung 3.4: Klonierung von Cops5 in pQM-NTag/A-Intron

Seite 47

Abbildung 3.5: $\quad$ Klonierung von Cops5 in pEGFP-C1

Seite 49

Abbildung 3.6: Klonierung von COPS5 in pDsRed2-N1

Seite 51

Abbildung 3.7: Fluoreszenzmikroskopische Untersuchung der subzellulären Lokalisation von Cops5 in NIH3T3-Zellen

Seite 54

Abbildung 3.8: Immunfluoreszenzmikroskopische Untersuchung der subzellulären Lokalisation von Spastin in NIH3T3-Zellen

Seite 55

Abbildung 3.9: Fluoreszenzmikroskopische Untersuchung der subzellulären Co-Lokalisation von COPS5 mit Spastin in NIH3T3-Zellen 
Abbildung 3.10: Immunfluoreszenzmikroskopische Untersuchung der subzellulären Co-Lokalisation von Cpos5 mit Spastin in NIH3T3-Zellen

Seite 58

Abbildung 3.11: Schematische Darstellung der Co-Immunopräzipitation

Seite 59

Abbildung 3.12: Co-Immunopräzipitation von Cops5 und Spastin nach Isolierung aus NIH3T3-Zellen

Seite 60

Abbildung 3.13: Basenaustausch im COPS5-Gen bei Patienten mit klinisch diagnostizierter HSP

Seite 62

Abbildung 4.1: $\quad$ Schematische Darstellung der Spastin-Struktur

Seite 64

Abbildung 4.2: $\quad$ Schematische Darstellung der COPS5-Struktur 


\section{Tabellenverzeichnis}

Tabelle 1.1: Übersicht der Genloci und der entsprechenden Genprodukte im Zusammenhang mit der Spastischen Paraplegie

Seite 3

Tabelle 1.2: Lokalisation der vier Gene der putativen Interaktionspartner des Spastins und ihr assoziierter HSP-Locus

Seite 6

Tabelle 3.1: Übersicht der Veränderungen im COPS5-Gen bei Patienten mit klinisch diagnostizierter Hereditärer Spastischer Paraplegie

Seite 62

Tabelle 4.1: Übersicht der Spastinisoformen und ihrer Molekulargewichte

Seite 66

Tabelle 4.2: Übersicht der autosomal-rezessiven Genloci und der entsprechenden Genprodukte im Zusammenhang mit der Spastischen Paraplegie 


\section{$1 \quad$ Einleitung}

\subsection{Hereditäre Spastische Paraplegien}

\subsection{1 Überblick}

Die Hereditären Spastischen Paraplegien (HSP) bilden eine klinisch und genetisch heterogene Gruppe neurodegenerativer Erkrankungen. Neben anderen Synonymen sind sie nach ihren Erstbeschreibern auch unter dem Begriff Strümpell-Lorrainsche Erkrankung bekannt. Der Leipziger Neurologe Adolf Strümpell lieferte 1880 die erste ausführliche Darstellung des Krankheitsbildes.

Hauptkennzeichen ist eine progrediente spastische Tonuserhöhung mit Hyperreflexie der unteren Extremitäten (Bruyn und Scheltens, 1991). Diese Symptomatik findet ein neuropathologisches Korrelat in einer Degeneration der kaudalen Pyramidenbahn und der Hinterstränge des Rückenmarks (Harding, 1984).

Die epidemiologische Datenlage zur HSP ist schwach und scheint regionale Unterschiede zu zeigen. In West-Norwegen wird die Prävalenz auf 14/100 000 Einwohner geschätzt (Skre, 1974), während sich in Dänemark eine Prävalenz von 0,9/100 000 Einwohner fand (Werdelin, 1986).

Da die Erkrankung einer kausalen Therapie noch nicht zugänglich ist, beschränkt sie sich auf eine rein symptomatische Behandlung mit Physiotherapie und Antispastika (Paulus et al., 2002).

\subsubsection{Klinisches Bild}

Die HSP zeigt zwei erkennbare zeitliche Krankheitsgipfel. Der erste liegt vor dem sechsten Lebensjahr, der zweite zwischen dem zweiten und vierten Lebensjahrzehnt (Paulus et al., 2002). Weitere Symptome neben einer Muskelschwäche sind ein positives Babinski-Zeichen, Blasenentleerungsstörungen und ein reduziertes Vibrationsempfinden in den unteren Extremitäten (Bruyn und Scheltens, 1991).

Man unterscheidet zwischen einer unkomplizierten bzw. reinen und einer komplizierten Form der HSP. Bei letzterer treten zusätzliche neurologische 
Symptome in Erscheinung. Dazu zählen Taubheit, Optikusatrophie, Demenz und mentale Retardierung (Fink, 2002).

Harding (1981) unterteilte die unkomplizierte autosomal-dominante HSP klinisch anhand des Alters bei Symptomauftreten in einen vor dem 35. Lebensjahr auftretenden Typ 1 und einen nach dem 35. Lebensjahr auftretenden Typ 2. Neben dem unterschiedlich starken Hervortreten von Spastik und Muskelschwäche unterscheiden sich diese durch eine raschere Progredienz und vermehrte Begleitsymptomatik beim Typ 2. Allerdings ist Auftreten und Ausprägung der Symptomatik einer inter- und intrafamiliären Variabilität unterworfen (Sauter et al., 2002).

\subsubsection{Genetik}

Das Vererbungsmuster der HSP folgt, sowohl für die reinen als auch die komplizierten Formen, autosomal-dominanten, autosomal-rezessiven und Xchromosomal-rezessiven Erbgängen.

Die häufigste Form ist mit bis zu 80 \% die autosomal-dominante HSP (Tallaksen et al., 2001). Während auf die autosomal-rezessive Form etwa $20 \%$ entfallen, ist die $\mathrm{X}$-chromosomale HSP selten und nur in einzelnen Familien anzutreffen. Insgesamt konnten bis dato 39 Loci mit HSP assoziiert und 16 Genprodukte identifiziert werden (Tab. 1.1). Das zum Locus 2p21-24 gehörige SPG4-Gen konnte 1999 von Hazan et al. isoliert und Mutationen in diesem bei Patienten mit autosomaldominanter HSP gezeigt werden. Das aus 17 Exons bestehende Gen erstreckt sich dabei über einen Bereich von etwa $90 \mathrm{~kb}$ und kodiert für das Genprodukt Spastin. Mutationen in diesem Gen sind für ungefähr 40 \% der gesicherten autosomaldominanten HSP verantwortlich (Sauter et al., 2002). 


\begin{tabular}{|c|c|c|c|c|}
\hline & Genlocus & Genprodukt & Vererbung & HSP-Form \\
\hline SPG1 & $\mathrm{Xq} 28$ & L1-CAM & X-chromosomal & $\begin{array}{l}\text { rein und } \\
\text { kompliziert }\end{array}$ \\
\hline SPG2 & $\mathrm{Xq} 22$ & PLP & X-chromosomal & $\begin{array}{l}\text { rein und } \\
\text { kompliziert }\end{array}$ \\
\hline SPG3A & $14 q 11-q 21$ & Atlastin & autosomal-dominant & rein \\
\hline SPG4 & $2 \mathrm{p} 21-\mathrm{p} 24$ & Spastin & autosomal-dominant & \begin{tabular}{|l} 
rein und \\
kompliziert
\end{tabular} \\
\hline SPG5 & 8q12-q13 & noch unbekannt & autosomal-rezessiv & rein \\
\hline SPG6 & $15 q 11$ & NIPA 1 & autosomal-dominant & rein \\
\hline SPG7 & $16 q 24.3$ & Paraplegin & autosomal-rezessiv & \begin{tabular}{|l|} 
rein und \\
kompliziert
\end{tabular} \\
\hline SPG8 & $8 q 24.13$ & KIAA0196 & autosomal-dominant & rein \\
\hline SPG9 & 10q23.3-q24.2 & unbekannt & autosomal-dominant & kompliziert \\
\hline SPG10 & $12 q 13$ & KIF5A & autosomal-dominant & rein \\
\hline SPG11 & $2 q 33.1$ & Spatacsin & autosomal-rezessiv & rein \\
\hline SPG12 & $19 q 13$ & unbekannt & autosomal-dominant & rein \\
\hline SPG13 & $2 q 24-q 34$ & HSP60 & autosomal-dominant & rein \\
\hline SPG14 & $3 q 27-q 28$ & unbekannt & autosomal-rezessiv & kompliziert \\
\hline SPG15 & $14 q 22-q 24$ & Spastizin & autosomal-rezessiv & kompliziert \\
\hline SPG16 & $\mathrm{Xq} 11.2$ & unbekannt & X-chromosomal & \begin{tabular}{|l|} 
rein und \\
kompliziert
\end{tabular} \\
\hline SPG17 & 11q12-q14 & Seipin (BSCL2) & autosomal-dominant & kompliziert \\
\hline SPG18 & Reserviert & & & \\
\hline SPG19 & 9q33-q34 & unbekannt & autosomal-dominant & rein \\
\hline SPG20 & $13 q 12.3$ & Spartin & autosomal-rezessiv & kompliziert \\
\hline$S P G 21$ & $15 q 22.31$ & Maspardin & autosomal-rezessiv & rein \\
\hline SPG22 & Reserviert & |------------------- & & ---------- \\
\hline$S P G 23$ & 1q24-q32 & unbekannt & autosomal-rezessiv & kompliziert \\
\hline SPG24 & $13 q 14$ & unbekannt & autosomal-rezessiv & rein \\
\hline
\end{tabular}




\begin{tabular}{|c|c|c|c|c|}
\hline SPG25 & 6q23.3-q24.1 & unbekannt & autosomal-rezessiv & rein \\
\hline SPG26 & 12p11.1-12q14 & unbekannt & autosomal-rezessiv & kompliziert \\
\hline SPG27 & 10q22.1-q24.1 & unbekannt & autosomal-rezessiv & rein \\
\hline SPG28 & $14 q 21.3-q 22.3$ & unbekannt & autosomal-rezessiv & rein \\
\hline SPG29 & 1p31.1-1p21.1 & unbekannt & autosomal-dominant & kompliziert \\
\hline SPG30 & $2 q 37.3$ & unbekannt & autosomal-rezessiv & kompliziert \\
\hline SPG31 & $2 \mathrm{p} 11.2$ & REEP1 & autosomal-dominant & rein \\
\hline SPG32 & $14 q .12-q 21$ & unbekannt & autosomal-rezessiv & rein \\
\hline SPG33 & $10 q 24.2$ & ZFYVE27 & autosomal-dominant & rein \\
\hline SPG34 & $\mathrm{Xq} 25$ & unbekannt & X-chromosomal & rein \\
\hline SPG35 & 16q21-q23.1 & unbekannt & autosomal-rezessiv & kompliziert \\
\hline SPG36 & $12 q 23-24$ & unbekannt & autosomal-dominant & rein \\
\hline SPG37 & 8p21.1-q13.3 & unbekannt & autosomal-dominant & rein \\
\hline SPG38 & Reserviert & & & \\
\hline SPG39 & $19 p 13$ & unbekannt & autosomal-rezessiv & kompliziert \\
\hline
\end{tabular}

Tab. 1.1: Übersicht der Genloci und der entsprechenden Genprodukte im Zusammenhang mit der Spastischen Paraplegie. SPG = Spastische Paraplegie.

\subsection{Spastin}

Das 616 Aminosäure lange Genprodukt Spastin gehört zu den Proteinen der AAAFamilie (Hazan et al., 1999). Diese auch AAA-Kassette (ATPase associated with diverse cellular activity) genannte Region stellt eine hochkonservierte ATPaseDomäne da. Mitglieder dieser Familie zeichnen sich durch eine Beteiligung an zellulären Prozessen wie Zellzyklusregulation, Proteolyse im 26SProteasomensystem und Vesikeltransport aus (Patel und Latterich, 1998).

Mittlerweile sind über 100 Spastinmutationen beschrieben, darunter eine Vielzahl von Missensemutationen, Nonsensemutationen, Leserahmenverschiebungen und 
Spleißmutationen, sowie weniger häufig Deletionen (Reid, 2003). Die Mutationen liegen verteilt über das gesamte Gen, wobei die am häufigsten auftretenden Missensemutationen eine Akkumulation in dem für die AAA-Kasette kodierenden Bereich zeigen (Bürger et al., 2000; Fonknechten et al., 2000; Lindsey et al., 2000; Sauter et al., 2002). Eine Ausnahme bildet hier das Exon 4 des SPG4-Gens, in dem bisher keine Mutationen identifiziert werden konnten. Im Blut und Gehirn konnten alternativ gespleißte Varianten des SPG4-Transkriptes nachgewiesen werden. Insbesondere im Rückenmark finden sich SPG4-Transkripte ohne das Exon 4 (Svenson et al., 2001; Proukakis et al., 2002).

Die subzelluläre Lokalisation des Spastins ist ebenso wie seine Funktion noch Diskussionsgegenstand. Während eine Studie die Lokalisation von Spastin im Nukleus postulierte (Charvin et al., 2003), demonstrierten Beetz et al. (2004) eine Expression auch im Zytoplasma. Zusätzlich fand sich eine komplexe subzelluläre Lokalisation in Abhängigkeit vom Zellzyklus (Errico et al., 2004). Studien zeigten, dass Spastin an der Dynamik des Zytoskeletts beteiligt ist. Durch die in der Nterminalen Region gelegene MIT (Microtubule Interacting and Trafficking)Domäne interagiert Spastin mit den Mikrotubuli des Zytoskeletts (Errico et al., 2002). Demgegenüber wird auch auf eine mögliche Rolle des Spastins im intrazellulären Membranverkehr verwiesen (Reid et al., 2005).

\subsection{Mutationen in putativen Interaktionspartnern des Spastins als Ursache einer HSP}

Die autosomal-dominant vererbte Form der HSP ist mit Abstand die häufigste. Innerhalb dieser Gruppe wiederum haben Mutationen im SPG4-Gen einen Anteil von 40 \%, Mutationen im SPG3A-Gen von 10 \% (Zhao et al., 2001). Das bedeutet, eine molekulargenetische Analyse dieser beiden Gene in klinisch diagnostizierten Patienten mit HSP deckt etwa die Hälfte der ursächlichen Mutationen auf. Jedoch lässt sich bei den anderen Patienten so die zugrunde liegende Mutation nicht finden. Hier besteht die Möglichkeit, dass andere mit HSP assoziierte Gene ursächlich sind, ein als genetische Heterogenität bezeichnetes Prinzip.

Heterogenität findet sich auch bei der Retinitis pigmentosa (RP), einer Erkrankung mit Nachtblindheit und fortschreitender Einschränkung des Gesichtsfeldes 
(Heckenlively, 1988). Sie beruht auf einer progressiven Degeneration von Photorezeptorzellen durch Apoptose (Portera-Cailliau et al., 1994). Ähnlich wie bei der HSP ist das Vererbungsmuster in den meisten Fällen autosomal-dominant, autosomal-rezessiv oder X-chromosomal. Inzwischen sind 45 Genorte und eine Vielzahl von Genprodukten bekannt (Hamel, 2006). Meindl et al. konnten 1996 das RP3-Gen identifizieren, das ein RPGR (Retinitis-pigmentosa-GTPase-Regulator) genanntes Protein codiert. Mittels des Yeast-Two-Hybrid-Systems konnte ein Interaktionspartner von RPGR, ein folglich RPGR-interacting protein 1 genanntes Genprodukt, identifiziert werden. Dieses verursacht im Falle von Mutationen ebenfalls eine RP (Roepman et al., 2000).

Ableitend aus dieser Tatsache ließ sich postulieren, dass auch Interaktionspartner des Spastins Kandidaten einer HSP sein könnten. Unter Verwendung des YeastTwo-Hybrid-Systems konnten im Rahmen einer Diplomarbeit vier putative Interaktionspartner des Spastins als mögliche Kandidatengene für die HSP identifiziert werden (Böhm, 2003). Auffällig ist, dass diese vier Loci in Bereichen lokalisierten, die direkt oder in der Nachbarschaft von HSP-assoziierten Loci liegen. Diese sind in Tabelle 1.2 aufgeführt.

\begin{tabular}{|l|l|c|}
\hline Putativer Interaktionspartner & Genlocus & Assoziierter HSP-Locus \\
\hline COPS5 & $8 \mathrm{q} 12.3$ & SPG5 \\
\hline FLJ40626 & $10 \mathrm{q} 23.3-24.2$ & SPG9 \\
\hline Reticulon1 & $14 \mathrm{q} 22$ & SPG15 \\
\hline Reticulon3 & $11 \mathrm{q} 13$ & SPG17 \\
\hline
\end{tabular}

Tab. 1.2: Lokalisation der vier Gene der putativen Interaktionspartner des Spastins und ihr assoziierter HSP-Loci (nach Böhm 2003). 


\subsection{Ziele dieser Arbeit}

$\mathrm{Zu}$ den bisher bekannten HSP-Loci sind bis dato nur weniger als die Hälfte der entsprechenden Genprodukte identifiziert. Daher kommen Mutationen in Genen für putative Interaktionspartner des Spastins, wie COPS5, als genetische Ursache für eine HSP in Frage. Würde sich diese Hypothese als richtig erweisen, könnte eine molekulargenetische Analyse dieser Gene etabliert werden und so einem weiteren Teil der HSP-Patienten helfen, ihre Krankheitsursache zu definieren. Daher waren die Ziele dieser Arbeit:

1. Transkriptanalyse des murinen Cops5 in verschiedenen Organen von Wildtyp-Mäusen mittels RT-PCR.

2. Co-Lokalisationsstudien und Interaktionsstudien von Cops5 mit Spastin mittels Immunfluoreszenz und Co-Immunopräzipitation zur Verifikation der Interaktion.

3. Sequenzierung des COPS5-Gens von Patienten mit klinisch diagnostizierter HSP, bei denen Mutationen im SPG4- und SPG3A-Gen nicht detektiert werden konnten. 


\section{$2 \quad$ Material und Methoden}

\section{$2.1 \quad$ Material}

\subsubsection{Chemikalien und Bioreagenzien}

Nicht gesondert aufgeführte Chemikalien wurden von der Firma Merck (Darmstadt) in p.A.-Qualität bezogen.

$\left[\alpha-{ }^{32} \mathrm{P}\right] \mathrm{dCTP}$

1kb DNA ladder

Agar

Agarose

Ampicillin

Ampuwa

Aprotinin

BCIP

Blocking Reagenz

Bromphenolblau

BSA (Faktor V)

Chloroform

Coomassie-Brilliant-Blau R250

DEPC

DMEM

DMSO

dNTPs

DPBS

DTT

EDTA

Essigsäure

Ethanol

Ethidiumbromid

FKS
Amersham Pharmacia Biotech GmbH, Freiburg

Invitrogen $\mathrm{GmbH}$, Karlsruhe

Sigma-Aldrich GmbH, Taufkirchen

PEQLAB Biotechnologie GmbH, Erlangen

Sigma-Aldrich Chemie GmbH, Taufkirchen

Fresenius AG, Bad Homburg

Sigma-Aldrich Chemie GmbH, Taufkirchen

Boehringer, Mannheim

Carl Roth GmbH \& Co., Karlsruhe

Sigma-Aldrich Chemie GmbH, Taufkirchen

Biomol, Hamburg

Sigma-Aldrich Chemie GmbH, Taufkirchen

Sigma-Aldrich GmbH, Taufkirchen

Carl Roth GmbH \& Co., Karlsruhe

Gibco/BRL, Karlsruhe

Sigma-Aldrich Chemie GmbH, Taufkirchen

Invitrogen $\mathrm{GmbH}$, Karlsruhe

PAN Biotech GmbH

Biomol GmbH, Hamburg

ICN Biomedicals GmbH, Eschwege

Carl Roth GmbH \& Co., Karlsruhe

Carl Roth GmbH \& Co., Karlsruhe

Carl Roth GmbH \& Co., Karlsruhe

Gibco/BRL, Karlsruhe 
Glycerin

IPTG

Kanamycin

Lachsspermien-DNA

MOPS

NBT

Restriktionsendonukleasen

RNase A

RNase-freies Wasser

RNase-Inhibitor

SDS

T4-DNA-Ligase

Triton X-100

Tris Base

Tween-20

Vectashield Mounting® Medium $\mathrm{X}-\beta \mathrm{Gal}$
ICN Biomedicals GmbH, Eschwege

Biomol GmbH, Hamburg

Sigma-Aldrich Chemie GmbH, Taufkirchen

Sigma-Aldrich Chemie GmbH, Taufkirchen

Sigma-Aldrich Chemie GmbH, Taufkirchen

Carl Roth GmbH \& Co., Karlsruhe

Invitrogen $\mathrm{GmbH}$, Karlsruhe

Gibco/BRL, Karlsruhe

QIAGEN GmbH, Hilden

QIAGEN GmbH, Hilden

ICN Biomedicals GmbH, Eschwege

Invitrogen $\mathrm{GmbH}$, Karlsruhe

Serva, Heidelberg

Carl Roth GmbH \& Co., Karlsruhe

Fluka, Deisenhofen

Paesel \& Lorei GmbH \& Co., Hanau

Biomol GmbH, Hamburg

\subsubsection{Gebrauchsfertige Reaktionssysteme („Kits“)}

DYEnamic ET-Terminator Mix

Hexalabel $^{\mathrm{TM}}$ DNA Labeling Kit

HotStar Taq-Mastermix

Lipofectamin $2000^{\mathrm{TM}}$ Transfection

Reagenz

pGEM®-T Easy Vector System

QIAEX II Gel Extraction Kit

QIAGEN Plasmid Midi Kit

QIAGEN EndoFree Plasmid Maxi Kit

ROCHE® One Step RT-PCR Kit
Amersham Pharmacia Biotech GmbH, Freiburg

MBI Fermentas GmbH, St. Leon-Rot

QIAGEN GmbH, Hilden

Invitrogen $\mathrm{GmbH}$, Karlsruhe

Promega GmbH, Mannheim

QIAGEN GmbH, Hilden

QIAGEN GmbH, Hilden

QIAGEN GmbH, Hilden

Boehringer Mannheim GmbH,

Mannheim 


\subsubsection{Gebrauchswaren}

Nicht gesondert aufgeführte Gebrauchswaren stammten von den Firmen Krannich GmbH \& Co. KG (Göttingen) und Schütt Labortechnik GmbH (Göttingen).

Blottingpapier GB001-004

Centrisart I-Zentrifugationsröhrchen

Hybond $^{\mathrm{TM}}$-XL Nitrocellulose

MicroSpin $^{\mathrm{TM}}$ S-200 H

Montage ${ }^{\circledR P C R}$ filter devices

Plastikwaren

Röntgenfilm Hyperfilm ${ }^{\mathrm{TM}} \mathrm{MP}$

Sterilfilter

Zellkulturflaschen
Schleicher \& Schüll GmbH, Dassel

Sartorius AG, Göttingen

Amersham Pharmacia Biotech GmbH, Freiburg

Amersham Pharmacia Biotech GmbH, Freiburg

Millipore GmbH, Schwalbach

Greiner, Solingen und Falkon, Heidelberg

Amersham Pharmacia Biotech GmbH, Freiburg

Sartorius AG, Göttingen

Greiner, Nürtingen

\subsubsection{Geräte}

Entwicklungsgerät Gevamatic 110 U

Kühlzentrifuge, 5417R

Magnetrührer

Megafuge1.0 R

Mikroskop BX60

Tischzentrifuge 5415C

Thermocycler Perkin Elmer

Thermocycler Primus

Transilluminator, UVT-28M

TurboBlotter ${ }^{\mathrm{TM}}$
Agfa Gevaert, München

Eppendorf, Hamburg

Schütt Labortechnik, Göttingen

Heraeus GmbH, Hanau

Olympus, München

Eppendorf, Hamburg

Applied Biosystems, Weiterstadt

MWG-Biotech, Ebersberg

Herolab GmbH, Wiesloch

Schleicher \& Schüll GmbH, Dassel 


\subsubsection{Vektoren}

pGEM-T Easy

pDsRed2-N1

pEGFP-C1

pQM-NTag/A intron
Promega, Mannheim

BD Clontech, Heidelberg

BD Clontech, Heidelberg

Abcam, Cambridgeshire, UK

\subsubsection{Oligonukleotide}

Die folgend aufgeführten Primer (Länge in Basenpaaren) wurden durch die Firma Qiagen (Hilden) synthetisiert und nach Erhalt mit $\mathrm{dH}_{2} \mathrm{O}$ auf eine Konzentration von $100 \mathrm{pmol} / \mu \mathrm{l}$ gelöst. Die Lagerung erfolgte bei $-20^{\circ} \mathrm{C}$.

\begin{tabular}{|l|l|c|}
\hline \multicolumn{1}{|c|}{ Name } & \multicolumn{1}{c|}{ Sequenz $5^{\prime}-$ 3 $^{\prime}$} & Länge \\
\hline Cop-1F & CGT CAT GTC CCG GAA AGG TCC CTG TCT TC & 29 \\
\hline Cop-1R & GTC GGT GAA AGC TCT TCA CCC CTT TCA C & 28 \\
\hline Cop-2F & GTA GTC TAC ACT CCC TTT CCA TCG CTC T & 28 \\
\hline Cop-2R & CAG GCT TTT AAT CTC GTA CAT TTT ACA TAT & 30 \\
\hline Cop-3F & GCC CAT AGA TTT CGC ATC TGG GCT GAG & 27 \\
\hline Cop-3R & GTC CCA GCT TCT AAG AGA TGG AAT TCA C & 28 \\
\hline Cop-4F & CTG TGA GAC ACT TAT ATT ACC CTC TTA CTG & 30 \\
\hline Cop-4R & GAG TTG GCT TGA GCC TAG GCG ATG AAG GCT & 31 \\
\hline Cop-5F & GCC TCC GAA AGT TAA TAA TCC TAT TAT TAG & 30 \\
\hline Cop-5R & GGA CTG GTT GAT ATC TAA GGT TTC TTT AGG & 30 \\
\hline Cop-6F & GTA GGA GAT TTG GAT CCA CAA CCC TTG AAG & 30 \\
\hline Cop-6R & GGC CAA GTC AGG TAT AGC CTT TCT GTG & 27 \\
\hline Cop-7F & CCT CAC TGA CTA TTC ACT CAG ATT TTA CAG & 30 \\
\hline Cop-7R & CAG GTA CCA TTC TAA GTT GTA ACT AAC TTG & 30 \\
\hline Cop-8F & GGA GTT ACA TGG ATG GAT TGG GGC TGA TC & 29 \\
\hline Cop-8R & CCG TAA TGG ATA CTA GAA AAA TAT TGC G & 28 \\
\hline & & 28 \\
\hline F1-cops5 & GGA AGG TCC AAA GCC CGC ACG CTG AGG C & 28 \\
\hline F2-cops5 & TCT TGA TTG TGG AGC GAC AGC TTC TCC GGT & 30 \\
\hline R1-cops5 & TTT TAT TAC AGT GCT AAT ACT CAG GAC A & 28 \\
\hline R2-cops5 & TTC CTT CCA CAC ACC AGC TTT GAG AAG T & 28 \\
\hline R3-cops5 & CCG AGC ATC AAA CCC ATC ACT TCC AAG T & 28 \\
\hline R4-cops5 & AGC AAC GTT AAT CTG ATT AAA CAG TTT AT & 29 \\
\hline & & 30 \\
\hline F1-COPS5 & ATA ATT TTC CGA GAC AAG ATG TTC TCA TTT & 30 \\
\hline F2-COPS5 & TCC CGT GGT GCG GAG GGT CAA GGC CCA CAC & 30 \\
\hline R1-COPS5 & GGA CAC TTC AGA GCA CCT TAT ACT TCT AAT & 30 \\
\hline
\end{tabular}




\begin{tabular}{|l|l|c|}
\hline R2-COPS5 & CTG TCT TTC AGG TAA AGT ACT TCT CAG AGA & 30 \\
\hline & & \\
\hline F-Redhuman & CAA GCT TTC GGC GAT GGC GGC GTC CGG G & 28 \\
\hline R-Redhuman & GGG ATC CGG AGA GAT GTT AAT TTG ATT & 27 \\
\hline (F)-EGFP & CAA GCT TCC GCA GCT TCC GGG AGT GGT ATG & 30 \\
\hline (R)-EGFP & GAG ATC TCT AAG CAA CGT TAA TCT GAT T & 28 \\
\hline $\begin{array}{l}\text { (F)-pQM- } \\
\text { NTag }\end{array}$ & CAA GCT TGC AGC TTC CGG GAG TGG TAT G & 28 \\
\hline $\begin{array}{l}\text { (R)DsRed2- } \\
\text { N1 }\end{array}$ & CAC GGT GCC CTC CAT GCG CAC CTT GAA & 27 \\
\hline $\begin{array}{l}\text { (F)pEGFP-C1 } \\
\begin{array}{l}\text { (F)pQM- } \\
\text { NTag/A-I. }\end{array}\end{array}$ & TCT AGA GCC ATG GGT TCA AGT ACT TCT & 27 \\
\hline
\end{tabular}

\subsubsection{Antikörper}

Die folgenden Antikörper wurden von der Firma Sigma-Aldrich Chemie GmbH (Taufkirchen) bezogen:

monoklonales Kaninchen-Anti-Myc-IgG

Ziege-Anti-Kaninchen-IgG-Cy3-Konjugat

Ziege-Anti-Maus-IgG-FITC-Konjugat

Ziege-Anti-Kaninchen-IgG-Alkalische-Phosphatase-Konjugat

Der folgende Antikörper wurde von der Firma Acris GmbH (Hiddenhausen) bezogen:

monoklonales Maus-Anti-E2-IgG

\subsubsection{Bakterienstämme}

Zur Amplifikation von Plasmiden wurden kompetente Bakterien vom Stamm Escherichia coli K12 DH 5 $\alpha$ der Firma Invitrogen, Karlsruhe verwendet.

Genotyp: $\quad \mathrm{F}^{-}$ф80d lacZ $\Delta \mathrm{M} 15$ endA1 recA1 hsdR17 $\left(\mathrm{r}_{\kappa}^{-}, \mathrm{m}_{\kappa}{ }^{+}\right)$sup E44 thi-1 dgyrA964(lacZYA-arg) 


\subsubsection{Bakterienkulturmedien und LB-Platten}

\subsubsection{Bakterienkulturmedien}

LB (Luria Bertani) -Medium (pH 7,5) $1 \%(w / v)$ Pepton

$0.5 \%(w / v)$ Hefe Extrakt

$0.5 \%(\mathrm{w} / \mathrm{v}) \mathrm{NaCl}$

Das Medium wurde mit $\mathrm{dH}_{2} \mathrm{O}$ angesetzt. Nach dem Autoklavieren und Abkühlen auf etwa $50^{\circ} \mathrm{C}$ wurden optional Antibiotika aus einer Stammlösung nach u.g. Schema zur selektiven Anzucht hinzugegeben.

Ampicillin Medium

Kanamycin Medium
$50 \mathrm{mg} / \mathrm{ml}$ Stammlösung auf eine Endkonzentration von $50 \mu \mathrm{g} / \mathrm{ml}$

$25 \mathrm{mg} / \mathrm{ml}$ Stammlösung auf eine Endkonzentration von $25 \mu \mathrm{g} / \mathrm{ml}$

\subsubsection{LB-Platten}

Für die Herstellung von LB-Platten wurde entsprechendes LB-Medium vor dem Autoklavieren mit 1,5 \% (w/v) Agar versetzt und zusammen mit 1mM IPTG und 2 \% X-Gal in Petrischalen gegossen. Nach dem Aushärten wurden die Platten, ebenso wie das Flüssigmedium, bei $4^{\circ} \mathrm{C}$ gelagert.

\subsubsection{Zelllinien und Zellkulturmedien}

\subsubsection{Zelllinien}

Bei der zur Transfektion genutzten Zelllinie handelt es sich um embryonale Mausfibroblasten (NIH3T3-Zellen). 
[Swiss 3T3, American Type Culture Collection, Rockville, USA “NIH Swiss Mouse”]

\subsubsection{Zellkulturmedien}

Als Medium wurde Dulbecco’s Modified Eagle Medium (DMEM) mit 10 \% fetalem Kälberserum (FKS), 1 \% Penicillin/Streptomycin, 1 \% Sodium Pyruvat, sowie 2 mM L-Glutamin versetzt.

\subsubsection{Puffer und Lösungen}

Die verwendeten Puffer und Lösungen wurden, sofern nicht anders angegeben, je nach Bedarf mit deionisiertem Wasser $\left(\mathrm{dH}_{2} \mathrm{O}\right)$ oder Ampuwa (pyrogenfreies Wasser für molekularbiologisches Arbeiten) hergestellt. Sie sind, sofern nicht vom Hersteller stammend, in ihrer Zusammensetzung direkt mit der jeweiligen Methode beschrieben.

\subsubsection{Sterilisation}

Gebrauchswaren, Lösungen und Kulturmedien wurden je nach Eignung, in der Regel bei $121^{\circ} \mathrm{C}$ und $10^{5} \mathrm{~Pa}$ für mindestens 20 min im Dampfdruckautoklaven (Webco, Bad Schwartau) autoklaviert oder für 8 - 12 Stunden bei $180^{\circ} \mathrm{C}$ hitzesterilisiert. Hitzeempfindliche Lösungen wurde sterifiltirert (Sterilfilter mit Porengröße 0,2-0,45 $\mu \mathrm{m})$.

\subsubsection{Datenbanken}

Nukleotid- und Proteinsequenzen wurden mit der Sequenzdatenbank Genbank (http://www.ncbi.nlm.nih.gov) mit Hilfe des BLAST-Programms (Altschul et al., 1990) analysiert. 


\subsection{Methoden}

\subsubsection{Isolierung von Nukleinsäuren}

\subsubsection{Isolierung von Plasmid-DNA im analytischen Maßstab}

Die sog. Minipräp erlaubt die schnelle Isolierung einer geringen Menge von Plasmid-DNA zum Zwecke ihrer Analyse.

Hierfür wurden 5 ml LB-Medium, mit Zusatz des entsprechenden Antibiotikums (zumeist Ampicillin oder Kanamycin), mit einer E. coli Kolonie beimpft und über Nacht bei $37^{\circ} \mathrm{C}$ in einem Schüttler bei 160 rpm inkubiert. Nach Abnahme von 500 $\mu \mathrm{l}$ der Übernachtkultur zur Herstellung eines Glycerinstocks wurde der Rest der Bakterienkultur in einem E-Cup bei $4000 \mathrm{x} \mathrm{g}$ für $10 \mathrm{~min}$ pelletiert und der Überstand dekantiert. Resuspendiert und gevortext in $200 \mu \mathrm{l}$ P1-Lösung wurden die Bakterienzellen mittels $200 \mu \mathrm{l}$ P2-Lösung unter kurzem vorsichtigem Schwenken und Inkubation für 5 min bei Raumtemperatur lysiert. Die Lyse wurde anschließend durch Zugabe von $200 \mu$ l P3-Lösung gestoppt. Zentrifugation bei 14.000 x g für 20 min bewirkte eine Abtrennung von Proteinen, Membranbestandteilen und bakterieller genomischer DNA, während die Plasmid-DNA im klaren Überstand in Lösung blieb. Überführt in ein neues E-Cup wurde aus dem Überstand die DNA durch $700 \mu \mathrm{l}$ kaltes Isopropanol, sowie nochmaliger Zentrifugation bei $14000 \mathrm{x}$ g für 20 min präzipitiert. Nach erneutem Verwurf des Überstandes wurde das Pellet mit $200 \mu$ l 70\% Ethanol gewaschen. Nach der letztmaligen Zentrifugation bei 14000 x g für 10 min und Trocknen des Pellets wurde die Plasmid-DNA in $20 \mu$ l Ampuwa Wasser gelöst und konnte nach Testung der Präparationseffizienz mittels gelelektrophoretischer Auftrennung bei $-20^{\circ} \mathrm{C}$ gelagert werden.

$\begin{array}{ll}\text { P1-Lösung: } & 50 \mathrm{mM} \text { Tris-HCl, } \mathrm{pH} \mathrm{8,0} \\ & 10 \mathrm{mM} \text { EDTA } \\ & 100 \mu \mathrm{g} / \mathrm{ml} \text { RNase A } \\ & 200 \mathrm{mM} \mathrm{NaOH} \\ \text { P2-Lösung: } & 1 \% \mathrm{SDS} \\ & 2,55 \mathrm{M} \text { Kaliumacetat, } \mathrm{pH} 4,8\end{array}$




\subsubsection{Isolierung von Plasmid-DNA im präparativen Maßstab}

Mittels der sog. Midipräp wurden größere Mengen Plasmid-DNA unter Verwendung des Qiagen Midi Plasmid Kits in Anlehnung an das Protokoll des Herstellers präpariert. Die Methode beruht auf einer Modifikation der alkalischen Lyse (Birnboim und Doly, 1979) und anschließender Aufreinigung über eine Anionenaustauschersäule.

Eine E.coli Kolonie wurde in $200 \mathrm{ml}$ LB-Medium, versetzt mit einem entsprechenden Selektionsantibiotikum, inokuliert und über Nacht bei $37^{\circ} \mathrm{C}$ in einem Schüttler inkubiert. Die Bakterienzellen der Übernachtkultur wurden bei 5000 $\mathrm{x}$ g für $20 \mathrm{~min}$ und $4^{\circ} \mathrm{C}$ abzentrifugiert und das Pellet nach Verwerfen des Überstandes in $4 \mathrm{ml}$ RNase-haltiger P1-Lösung aufgenommen. Im Anschluss an eine Überführung der Suspension in ein Zentrifugenröhrchen wurden zur Lyse der Zellen $4 \mathrm{ml} \mathrm{P2-Lösung} \mathrm{zugegeben} \mathrm{und} \mathrm{nach} \mathrm{kurzem} \mathrm{Invertieren} 5 \mathrm{~min}$ bei Raumtemperatur inkubiert. Nach Zugabe von 4 ml P3-Lösung zur Neutralisation wurde der Ansatz 20 min auf Eis inkubiert. Es folgte eine Zentrifugation der Zelltrümmer bei $10000 \mathrm{x}$ g für $20 \mathrm{~min}$ bei $4^{\circ} \mathrm{C}$. Zeitgleich wurde eine Anionenaustauschersäule mit 4 ml QBT-Lösung äquilibriert. Diese wurde mit dem plasmidhaltigen Zentrifugationsüberstand beladen, so dass die Plasmid-DNA nach Durchlaufen der Lösung an das Säulenmaterial gebunden hatte. Nach zweimaligem Waschen mit $10 \mathrm{ml}$ QC-Lösung wurde die Plasmid-DNA mit $5 \mathrm{ml}$ QF-Lösung eluiert. Eine Zugabe von 3,5 ml Isopropanol und anschließende Zentrifugation bei 10000 x g für 20 min bei $4^{\circ} \mathrm{C}$ bewirkte eine Fällung und Sedimentierung der DNA. Abschließend wurde das Pellet mit 2 ml 70 \% Ethanol gewaschen und bei 10000 x g für 10 min bei $4^{\circ} \mathrm{C}$ letztmalig zentrifugiert. Nach Trocknen des Pellets wurde dieses in $200 \mu$ Ampuwa Wasser aufgenommen und konnte nach photometrischer Messung der DNA-Konzentration bei $-20^{\circ} \mathrm{C}$ gelagert werden.

$$
\begin{array}{ll}
\text { QBT-Lösung (Äquilibrierungspuffer): } & 750 \mathrm{mM} \mathrm{NaCl} \\
& 50 \mathrm{mM} \mathrm{Mops,} \mathrm{pH} 7 \\
& 15 \%(\mathrm{v} / \mathrm{v}) \text { Ethanol } \\
& 0,15 \%(\mathrm{v} / \mathrm{v}) \text { Triton X-100 }
\end{array}
$$




$\begin{array}{ll}\text { QC-Lösung (Waschpuffer): } & 1 \mathrm{M} \mathrm{NaCl} \\ & 50 \mathrm{mM} \text { MOPS, pH } 7 \\ & 15 \%(\mathrm{v} / \mathrm{v}) \text { Isopropanol } \\ & \\ \text { QF-Lösung (Elutionspuffer): } & 1,25 \mathrm{M} \mathrm{NaCl} \\ & 50 \mathrm{mM} \mathrm{Tris/HCl} \mathrm{pH} \mathrm{8,5} \\ & 15 \%(\mathrm{v} / \mathrm{v}) \text { Isopropanol }\end{array}$

\subsubsection{Endotoxin-freie Isolierung von Plasmid-DNA}

Zur Gewinnung Endotoxin-freier Plasmid-DNA wurde das EndoFree Plasmid Maxi Kit der Firma Qiagen benutzt. Hierbei ist ein Schritt zur Entfernung der Endotoxine enthalten, ansonsten entspricht das Protokoll der Gewinnung von Plasmid-DNA im präparativen Maßstab.

Zur Transfektion kultivierter Zellen ist es notwendig, Endotoxine nahezu restlos aus der DNA-Lösung zu entfernen. Als Endotoxine werden Lipopolysaccharide (LPS) aus der Zellwand gramnegativer Bakterien (wie E. coli) bezeichnet. Während des Lyseprozesses gelangen diese in das Lysat und könnten später die Transfektion sensitiver eukaryontischer Zellen beeinflussen. Ein erhöhter Gehalt an LPS senkt dabei die Transfektionsrate erheblich.

Anzucht und Lyse der Bakterienzellen erfolgte wie unter 2.2.1.2 beschrieben, nur wurde das Lysat jetzt nach Zugabe des Neutralisierungspuffers (P3-Lösung) in eine QIAfilter-Kartusche überführt und $10 \mathrm{~min}$ bei Raumtemperatur inkubiert. Zur Abtrennung des sich dabei sammelnden Präzipitats aus Proteinen, genomischer DNA und Detergens wurde dann der Verschluss der Kartusche entfernt und die Probe unter ständigem Druck durch die Filtrationseinheit in ein Zentrifugenröhrchen filtriert. Nach Zugabe von 2,5 ml ER-Lösung, eines Puffers zur Entfernung von Endotoxinen, wurde für 30 min auf Eis inkubiert. Der Inkubation folgend wurde die Probe auf eine, zwischenzeitlich mit $10 \mathrm{ml}$ QBT-Lösung äquibrilierte Qiagen-tip500-Säule, gegeben. Die ER-Lösung verhinderte hierbei die Bindung der LPS an das Material der Säule. Nach zweimaligem Waschen mit $30 \mathrm{ml}$ QC-Lösung wurde die nun Endotoxin-freie DNA mit $15 \mathrm{ml}$ QN-Lösung eluiert. 10,5 ml Isopropanol und 30 minütige Zenrifugation bei $15000 \mathrm{x}$ g und $4^{\circ} \mathrm{C}$ führten zur Pelletierung der 
DNA, die abschließend mit 70 \% Ethanol gewaschen wurde. Nach Trocknung wurde das Pellet in einem Endotoxin-freien Trägermedium resuspendiert und konnte nach einer photometrischen Konzentrationsmessung bei $-20^{\circ} \mathrm{C}$ gelagert werden.

ER-Lösung: Zusammensetzung nicht bekannt

QN-Lösung (Elutionspuffer): $\quad$ 1,6 M NaCl

$50 \mathrm{mM}$ MOPS, $\mathrm{pH} 7$

$15 \%(\mathrm{v} / \mathrm{v})$ Isopropanol

\subsubsection{Herstellung von Bakterien-Glycerinstocks}

Zur langfristigen Aufbewahrung von Bakterienkulturen wurden Glycerinstocks angelegt. $500 \mu \mathrm{l}$ einer Bakteriensuspension wurden mit $500 \mu \mathrm{l}$ sterilem Glycerin versetzt und konnten nach Durchmischen bei $-80^{\circ} \mathrm{C}$ gelagert werden.

\subsubsection{Konzentrationsbestimmung von Nukleinsäuren}

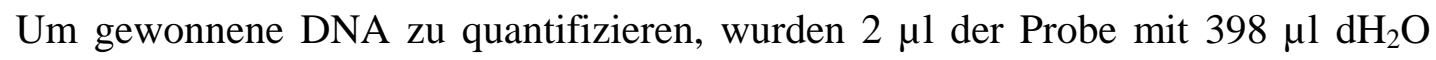
verdünnt und in eine Präzisionsküvette aus Quarzglas (Hellma) pipettiert. Mit dem auf Xenon-Spektrallinienbasis arbeitenden BioPhotometer der Firma Eppendorf konnte anschließend die Nukleinsäurekonzentration ermittelt werden. Diese basierte auf einer Extinktionsmessung bei $260 \mathrm{~nm}$.

\subsubsection{Aufreinigung von Nukleinsäuren}

\subsubsection{Ethanolfällung von DNA}

Die Ethanolfällung wurde als Reinigungsschritt eingesetzt um DNA von niedermolekularen Kontaminationen $\mathrm{zu}$ befreien und so einer effizienten enzymatischen Weiterverarbeitung zugänglich zu machen. 
Zugabe von 1/10 des Ansatzvolumens an $3 \mathrm{M}$ Natriumacetat $\mathrm{pH}$ 4,8 sowie des 2,4fachen Volumens an 100 \% Ethanol zur DNA mit anschließender Inkubation von 20 min bei $-80^{\circ} \mathrm{C}$ führten zur Präzipitation. Nach Zentrifugation bei $12000 \mathrm{x}$ g für 10 min wurde der Überstand verworfen und das Pellet mit 70 \% Ethanol einem Waschschritt mit letztmaliger Zentrifugation unter gleichen Bedingungen, unterzogen. Das getrocknete Pellet wurde abschließend in $20 \mu \mathrm{ll} \mathrm{dH}_{2} \mathrm{O}$ aufgenommen.

\subsubsection{Aufreinigung von PCR-Produkten über Microcon-PCR-Säulen}

Um PCR-Produkte von Enzymen, Salzen und Kontaminationen sowie überschüssigen Primern abzuscheiden, wurden diese mittels eines Microcon-PCRUltrazentrifugationsröhrchens (Millipore) gefiltert.

Zunächst wurde mittels Agarosegelelektrophorese an einem Aliquot des PCRAnsatzes überprüft, ob die Amplifikation erfolgreich war. Anschließend wurde der restliche Ansatz auf die Membran einer in einem 1,5 ml Cup sitzende Säule gegeben, mit $\mathrm{dH}_{2} \mathrm{O}$ auf $500 \mu \mathrm{l}$ aufgefüllt und für 15 min bei 3500 x g zentrifugiert. Die Säule wurde gewendet, in ein neues Cup gestellt, mit dem gewünschten Volumen $\mathrm{dH}_{2} \mathrm{O}$ befüllt und durch erneute Zentrifugation bei $2000 \mathrm{x}$ g für 5 min die DNA eluiert.

\subsubsection{Aufreinigung von DNA-Fragmenten aus Agarosegelen}

Die vollständige Aufreinigung von aus Agarosegelen isolierten DNA-Fragmenten erfolgte mit Hilfe des QIAEX II Gel Extraction Kits (Hilden). Zugrunde liegendes Prinzip dieser Methode ist eine durch hohe Salzkonzentrationen reversible Adsorption der DNA an eine Silikatsuspension, während die Salze gleichzeitig die Wasserstoffbrückenbindungen der Agarosepolymere lösen. Am Ende führt ein Absenken der Salzkonzentration wieder zur Elution der DNA.

Das nach elektrophoretischer Auftrennung mittels Skalpell isolierte Gelstück wurde in einem E-Cup gewogen, mit QX1-Lösung sowie mit $10 \mu$ l einer Silikonsuspension versetzt und gemischt. Dabei wurde pro $1 \mathrm{mg}$ Gewicht $3 \mu$ Lösung hinzugefügt. 
Inkubation des Ansatzes bei $50^{\circ} \mathrm{C}$ für 10 min auf dem Thermoschüttler bewirkte ein Auflösen der Agarose und binden der DNA an die Silikatpartikel. Zentrifugation bei 10000 x g für 30 sec führte zur Pelletierung der Glasmilch. Nach Abnahme des Überstandes wurde einmalig mit 500 $\mu$ Q QXI gewaschen sowie zur Entfernung aller Salze und Verunreinigungen zweimalig mit $500 \mu$ l ethanolhaltiger PE-Lösung. Anschließend wurde das Pellet getrocknet und in 20 $\mu$ Ampuwa Wasser aufgenommen. Der Ansatz wurde nach 5 min Elution der DNA bei Raumtemperatur letztmalig unter selbiger Kondition zentrifugiert und der Überstand in ein neues Cup überführt. Zur Maximierung der Ausbeute konnte dieser Schritt wiederholt werden. $2 \mu \mathrm{l}$ des Eluats wurden abschließend zur Analyse auf ein Agarosegel aufgetragen und getestet.

\subsubsection{Enzymatische Modifikation von Nukleinsäuren}

\subsubsection{Analytische Restriktion}

Zur Analyse durch Plasmidpräparation gewonnener DNA kann diese mittels geeigneter Restriktionsendonukleasen gespalten und die entstandenen DNAFragmente nach gelelektrophoretischer Auftrennung beurteilt werden. Restriktionsendonukleasen sind Enzyme, die für das jeweilige Enzym spezifische, in der Regel palindromische Nukleotidsequenzen erkennen und die doppelsträngige DNA spalten.

Für analytische Restriktionen wurden ca. $1 \mu \mathrm{g}$ DNA in einem Gesamtreaktionsvolumen von $20 \mu \mathrm{l}$ verwandt. Ein typischer Ansatz setzt sich dabei zusammen aus:

$$
\begin{array}{ll}
1-2 \mu \mathrm{l} & \text { DNA } \\
2 \mu \mathrm{l} & 10 \times \text { Reaktionspuffer (vom Hersteller) } \\
1-2 \mu \mathrm{l} & \text { Restriktionsenzym }(10 \mathrm{U} / \mu \mathrm{l}) \\
\text { ad } 20 \mu \mathrm{l} & \mathrm{dH}_{2} \mathrm{O}
\end{array}
$$

Die Inkubation des Restriktionsansatzes erfolgte für $2-3$ h bei für das jeweilige Enzym optimaler Temperatur. Der 10 x Reaktionspuffer wird, nach Vorgabe des 
Herstellers, zur Optimierung der Reaktionsbedingungen hinzugefügt und beträgt 1/10 Volumen im Ansatz.

\subsubsection{Ligation von DNA-Fragmenten}

Die Ligation wurde benutzt, um restriktionsenzymatisch gespaltene und isolierte DNA-Fragmente in linearisierte Vektoren zu integrieren.

Das zu klonierende Fragment sollte dabei in 3fachem molaren Überschuß im Verhältnis zum Vektor dem Ansatz beigefügt werden. Dabei ergab sich folgender 10 $\mu$ Ligationsansatz:

$\begin{array}{ll}50 \mathrm{ng} & \text { Vektor-DNA } \\ 150 \mathrm{ng} & \text { Insert-DNA } \\ 1 \mu \mathrm{l} & \text { T4-DNA-Ligase } \\ 1 \mu \mathrm{l} & 10 \times \text { Ligationspuffer (vom Hersteller) } \\ \text { ad } 10 \mu \mathrm{l} & \mathrm{dH}_{2} \mathrm{O}\end{array}$

Der Ligationsansatz wurde über Nacht bei $4^{\circ} \mathrm{C}$ inkubiert.

\subsubsection{TA-Klonierung mit dem pGEM-T-Easy-Vektor-System}

Zum Einbringen von PCR-Produkten in einen Vektor wurde auf das pGEM-T-EasyVektor-System zurückgegriffen. Ausgenutzt wird hierbei die matrizenunabhängige terminale Transferaseaktivität, der für die PCR eingesetzten Taq-Polymerase, die am 3'-Ende ein einzelnes Nukleotid dATP anfügt. Ein T-Überhang am 5'-Ende des pGEM-T Easy-Vektros ermöglicht so die Ligation eines PCR-Produkts zur Klonierung, ohne das kompatible Enden mittels Restriktion erst generiert werden müssen. Der Ansatz erfolgte dabei analog zu 2.2.3.2 . 


\subsubsection{Transformation kompetenter Zellen mit Plasmid-DNA}

Als Transformation bezeichnet man die Übertragung genetischer Information in einen Organismus.

Für die Transformation wurden $5 \mu$ l eines über Nacht inkubierten Ligationsansatzes vorsichtig in ein $50 \mu \mathrm{l}$ Aliquot kompetenter DH5 $\alpha$-Zellen pipettiert und für $30 \mathrm{~min}$ unter gelegentlichem Mixen auf Eis inkubiert. Anschließend wurden die Zellen für 45 sec einem Hitzeschock bei $37^{\circ} \mathrm{C}$ ausgesetzt und wiederum auf Eis für 2 min abgekühlt. Nach Hinzufügen von $300 \mu$ l LB-Medium erfolgte eine 45 minütige Inkubation bei $37^{\circ} \mathrm{C}$ unter Schütteln auf dem Thermomixer. Abschließend wurden $200 \mu \mathrm{l}$ des Ansatzes auf spezifisch mit Antibiotika versetzten Agarplatten, für das der Vektor eine Resistenz kodierte, ausplattiert und über Nacht bei $37^{\circ} \mathrm{C}$ im Brutschrank inkubiert.

Wurde das pGEM-T-Easy-Vektor-System verwandt, wurde der Agarplatte neben dem Antibiotikum noch IPTG und X-Gal zur Blau-Weiß-Selektion zugesetzt. Klone mit Insert konnten kein funktionelles Enzym mehr bilden, welches X-Gal zu einem blauen Farbstoff umsetzt, und konnten so selektiert werden.

\subsubsection{Gelelektrophorese}

\subsubsection{Analytische Gelelektrophorese}

Zur Auftrennung von PCR-Produkten oder mit Restriktionsenzymen gespaltener DNA diente die Gelelektrophorese mit in Abhängigkeit der Länge der aufgetrennten DNA-Fragmente verschieden konzentrierten Agarosegelen. Färbung mit Ethidiumbromid erlaubte unter dem UV-Transilluminator eine spätere Sichtbarmachung der DNA.

Gewöhnlich wurde $1 \mathrm{~g}$ Agarose durch Aufkochen in der Mikrowelle in $100 \mathrm{ml}$ 0,5 $\mathrm{x}$ g TBE-Puffer (1 \%) gelöst und nach Abkühlung auf $60^{\circ} \mathrm{C}$ mit $10 \mu \mathrm{l}$ Ethidiumbromid (5 mg/ml) versetzt. Die Agaroselösung wurde so in einen zuvor abgedichteten Gelschlitten mit Probenkamm gegossen und, nach Aushärten zu einem Gel, in eine horizontale Elektrophoresekammer gelegt. Nach Überschichten des Gels mit 0,5 x TBE-Puffer konnten die mit 1/3 Volumen Probenpuffer 
versetzten DNA-Proben in die Geltaschen auf Höhe der Kathode aufgetragen werden. Zur Abschätzung der Fragmentgröße wurde gleichzeitig ein Marker als Längenstandard (1Kb-Ladder) mit aufgetragen. Die eingesetzte Spannung variierte, betrug aber zumeist um die $100 \mathrm{~V}$. Die Zeitdauer belief sich abhängig von der Größe der DNA-Fragmente auf 30 bis 60 min.

Beruhend auf dem Prinzip der DNA-Interkalation des Fluoreszenzfarbstoffs Ethidiumbromid, konnte die DNA durch Bestrahlung mittels UV-Licht (= $320 \mathrm{~nm}$ ) unter einem Transilluminator sichtbar gemacht werden. Im Anschluss erfolgte die photographische Dokumentation.

Probenpuffer:

$70 \%(\mathrm{v} / \mathrm{v})$ Glycerin

0,01\% (w/v) Bromphenolblau

$0,01 \%(w / v)$ Xylencyanol FF

\subsubsection{Präparative Gelelektrophorese}

Die präparative Gelelektrophorese diente der Auftrennung und Isolierung mittels restriktionsenzymatischer Prozesse gewonnener Plasmid-Inserts. Zumeist wurden 1 \% Agarosegele verwandt. Nach Abschluss des Laufes wurden die gewünschten DNA-Fragmente unter UV-Licht mittels eines sterilen Skalpells aus dem Agarosegel ausgetrennt, in ein E-Cup überführt und das Gewicht des Gelstücks ermittelt. Die sich anschließende Aufreinigung erfolgte mit dem QIAEX II Gelextraktion Kit. 


\subsubsection{Polymerase-Kettenreaktion (PCR)}

(Mullis und Faloona, 1987)

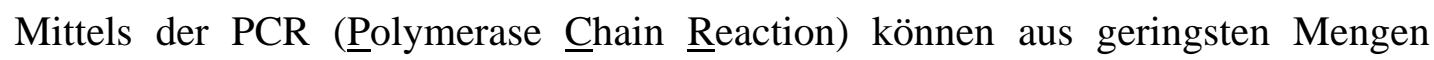
genetischen Materials innerhalb weniger Stunden spezifische Abschnitte in vitro exponentiell amplifiziert werden. Als Vorlage kommen z.B. genomische DNA, Plasmid-DNA, cDNA usw. in Frage.

Die Reaktion beruht auf zwei synthetischen Oligonukleotiden, die den zu amplifizierenden Bereich an beiden Enden flankieren und an den jeweiligen komplementären Strang nach vorheriger Denaturierung binden. Diese in entgegengesetzter Richtung orientierten Strukturen dienen als Ausgangspunkt für die DNA-Synthese mittels einer thermostabilen DNA-Polymerase (isoliert aus dem Archaebakterium Thermus aquaticus), die den Bereich zwischen den Oligonukleotiden neu bildet.

Das Prinzip ist die Wiederholung eines Zyklus von Denaturierung, Primeranlagerung und Synthese des Zweitstranges. Da jeder neu gebildete Strang als Matrize für die Synthese eines weiteren dient, kommt es im theoretisch optimalsten Fall zu einer Verdoppelung der Sequenz und damit im Verlauf zu einer exponentiellen Vervielfältigung des Materials.

\subsubsection{PCR an humaner genomischer DNA}

Vor der Sequenzierung der Exons sowie flankierender Bereiche des COPS5-Gens mussten diese mittels spezifischer Primer amplifiziert werden. Nachstehender Raktionsansatz kam dabei in einem $200 \mu$ l PCR-Tube zur Anwendung:

$\begin{array}{ll}300-500 \text { ng } & \text { humane genomische DNA } \\ 1 \mu \mathrm{l} & \text { „forward primer“ (10 pmol) } \\ 1 \mu \mathrm{l} & \text { „reverse primer“ (10 pmol) } \\ 25 \mu \mathrm{l} & \text { Hotstart Taq-Polymerase Mix (Qiagen) } \\ \text { ad } 50 \mu \mathrm{l} & \mathrm{dH}_{2} \mathrm{O}\end{array}$


Dieser wurde anschließend gemischt, zentrifugiert und in einem Thermocycler platziert. Folgendes Thermocycler-Programm wurde verwendet:

$\begin{array}{lll}\text { Initiale Denaturierung } & 96^{\circ} \mathrm{C} & 15 \mathrm{~min} \\ \text { Denaturierung } & 94^{\circ} \mathrm{C} & 40 \mathrm{sec} \\ \text { Anlagerung } & 60^{\circ} \mathrm{C} & 50 \mathrm{sec} \\ \text { Verlängerung } & 72^{\circ} \mathrm{C} & 1 \mathrm{~min} \\ & & \\ \text { letzter Verlängerungsschritt } & 72^{\circ} \mathrm{C} & 10 \mathrm{~min} .\end{array}$

Die initiale Denaturierung diente auch der Aktivierung der Taq-Polymerase. Der letzte Verlängerungsschritt erfolgte zur Vervollständigung der Synthese begonnener PCR-Produkte nur einmal. Die Schritte Denaturierung, Anlagerung und Verlängerung hingegen wurden in 35 Zyklen wiederholt.

Nach der Amplifikation wurden $5 \mu$ des PCR-Produktes in einem $1 \%$ Agarosegel aufgetrennt und bezüglich der Größe der Fragmente beurteilt. Die restlichen $45 \mu \mathrm{l}$ des PCR-Ansatzes wurden durch Aufreinigung einer anschließenden Sequenzierung zugänglich gemacht. 


\subsubsection{PCR an Plasmid-DNA}

Die PCR an Plasmiden hatte entweder die Amplifikation des ganzen oder nur von Teilen des Inserts zum Ziel. Ganze Inserts wurden mit Hilfe zweier auf beiden Seiten flankierender vektorspezifischer Primer vervielfältigt. Wurde nur ein Teil des Inserts amplifiziert, geschah dies mit zwei für das Insert spezifischen Primern oder aber mit einem für das Insert spezifischen und einem vektorspezifischen Primer.

Das Reaktionsschema sah dabei wie folgt aus:

$$
\begin{array}{ll}
3-5 \mathrm{ng} & \text { Plasmid-DNA } \\
1 \mu \mathrm{l} & \text { “forward primer” }(10 \mathrm{pmol}) \\
1 \mu \mathrm{l} & \text { "reverse primer” }(10 \mathrm{pmol}) \\
25 \mu \mathrm{l} & \text { Hotstart Taq-Polymerase Mix (vom Hersteller) } \\
\text { ad } 50 \mu \mathrm{l} & \mathrm{dH}_{2} \mathrm{O}
\end{array}
$$

Nach 15 min initialer Denaturierung bei $96^{\circ} \mathrm{C}$ schlossen sich 35 Zyklen des folgenden Thermocycler Programms an:

$\begin{array}{lll}\text { Denaturierung } & 94^{\circ} \mathrm{C} & 40 \mathrm{sec} \\ \text { Anlagerung } & 60^{\circ} \mathrm{C} & 50 \mathrm{sec} \\ \text { Verlängerung } & 72^{\circ} \mathrm{C} & 45-90 \mathrm{sec} .\end{array}$

Die Dauer der Verlängerung variierte je nach Größe des erwarteten PCR-Produktes. Abschließend erfolgte der letzte Elongationsschritt bei $72^{\circ} \mathrm{C}$ für $10 \mathrm{~min}$. Analog der genomischen DNA wurde eine Kontrolle des Reaktionsproduktes durchgeführt, der sich eine Sequenzierung nach Aufreinigung oder Isolierung anschloss. 


\subsubsection{Reverse-Transkriptase-PCR (RT-PCR)}

(Kogan et al., 1987)

Die RT-PCR-Technik ist eine Methode, die zum einen einen qualitativen Nachweis einer Genexpression erlaubt, zum anderen ermöglicht sie die Generierung einer cDNA-Sequenz zur weiteren Analyse.

Der RT-PCR dient als Ausgangsprodukt RNA, von der mittels einer Reversen Transkriptase ein der mRNA komplementärer Strang cDNA synthetisiert wird. Daran anschließend wird mittels spezifischer Primer und der cDNA als Matrize in einer PCR das gewünschte DNA-Fragment amplifiziert.

Für die in dieser Arbeit durchgeführten RT-PCR-Analysen und Erzeugung humaner sowie muriner cDNA wurde das ROCHE® Titan OneStep RT-PCR Kit verwendet. Dies bietet den Vorteil, dass sowohl Reverse Transkription als auch die PCR in einem Ansatz erfolgen.

$\begin{array}{ll}1 \mu \mathrm{g} & \text { Gesamt-RNA } \\ 10 \mu \mathrm{l} & 5 \text { x ROCHE® Titan OneStep RT-PCR Puffer } \\ 1 \mu \mathrm{l} & \text { „forward primer” (10 pmol) } \\ 1 \mu \mathrm{l} & \text { “reverse primer” (10 pmol) } \\ 1 \mu \mathrm{l} & \text { dNTP-Mix } \\ 1 \mu \mathrm{l} & \text { ROCHE® Titan OneStep RT-PCR DTT } \\ 1 \mu \mathrm{l} & \text { ROCHE® Titan OneStep RT-PCR Enzym-Mix } \\ \text { ad } 50 \mu \mathrm{l} & \text { DEPC d } \mathrm{d}_{2} \mathrm{O}\end{array}$

Um mögliche Kontaminationen zu erkennen, wurde bei Transkriptionsnachweis eines Gens in Geweben stets eine Nullkontrolle mitgeführt, in der RNA durch Wasser ersetzt wurde.

Das Programm der in einem Thermocycler Applied Biosystems von Perkin Elmer ablaufenden RT-PCR gliederte sich wie folgt. Zunächst wurde die Reverse Transkription bei $50^{\circ} \mathrm{C}$ für 30 min mit Erzeugung einer einzelsträngigen cDNA durchgeführt. Anschließend nach Aktivierung der Polymerase bei $94^{\circ} \mathrm{C}$ für 2 min, schlossen sich 10 Zyklen des folgenden Programms an: 


$\begin{array}{lll}\text { Denaturierung } & 94^{\circ} \mathrm{C} & 10 \mathrm{sec} \\ \text { Anlagerung } & 60^{\circ} \mathrm{C} & 30 \mathrm{sec} \\ \text { Verlängerung } & 68^{\circ} \mathrm{C} & 60 \mathrm{sec} .\end{array}$

Nach diesen 10 Zyklen schlossen sich noch einmal 25 Zyklen mit jeweils einer Ausdehnung des Verlängerungsschrittes um 5 sec an, um den sukzessiven Wirkungsverlust der Polymerase zu kompensieren. Abschließend erfolgte ein letzter Verlängerungsschritt bei $68^{\circ} \mathrm{C}$ für $7 \mathrm{~min}$. Nach Reaktionsende wurden Aliquots der PCR-Produkte im Agarosegel analysiert.

\subsubsection{Nested-PCR}

Ist die Ausgangsmenge an genetischem Material sehr gering, so existieren grundsätzlich zwei Möglichkeiten, eine ausreichende Amplifikatmenge zu erhalten: erstens die Steigerung der Anzahl der Zyklen, hier besteht aber eine steigende Wahrscheinlichkeit von Fehlhybridisierungen; zweitens eine Nested-PCR durchzuführen.

Mittels dieser Methode ist es möglich die Spezifität und Effizienz einer PCR weiter zu erhöhen, da das PCR-Produkt einer ersten Amplifikation als Vorlage für eine zweite PCR verwendet wird. Diese zweite PCR wird mit neuen spezifischen Primern durchgeführt, die innerhalb der Fragmente der ersten PCR liegen. Der folgende Ansatz wurde verwendet:

$\begin{array}{ll}1 \mu \mathrm{l} & \text { PCR-Produkt } \\ 1 \mu \mathrm{l} & \text { “forward primer 2” (10 pmol) } \\ 1 \mu \mathrm{l} & \text { “reverse primer 2” (10 pmol) } \\ 25 \mu \mathrm{l} & \text { Hotstart Taq-Polymerase Mix (vom Hersteller) } \\ \text { ad } 50 \mu \mathrm{l} & \mathrm{dH}_{2} \mathrm{O}\end{array}$


An 15 min initialer Denaturierung und Enzymaktivierung bei $96^{\circ} \mathrm{C}$ schlossen sich 35 Zyklen im Thermocycler des folgenden Programms an:

$\begin{array}{lll}\text { Denaturierung } & 94^{\circ} \mathrm{C} & 40 \mathrm{sec} \\ \text { Anlagerung } & 60^{\circ} \mathrm{C} & 50 \mathrm{sec} \\ \text { Verlängerung } & 72^{\circ} \mathrm{C} & 1 \mathrm{~min} \\ & & \\ \text { letzter Verlängerungsschritt: } & 72^{\circ} \mathrm{C} & 10 \mathrm{~min} .\end{array}$

Dem letzten zur Vervollständigung der Synthese begonnener PCR-Produkte nur einmal durchgeführten Verlängerungsschritt folgte die Auftrennung von $5 \mu$ des PCR-Produktes in einem 1 \% Agarosegel. Die restlichen $45 \mu$ des PCR-Ansatzes wurden durch Aufreinigung einer anschließenden Sequenzierung zugänglich gemacht. 


\subsubsection{DNA-Sequenzierung}

Modifiziert, nach dem Kettenabbruchverfahren von Sanger et al. (1977), ermöglicht die Sequenzierung die Ermittlung der Basenabfolge eines DNA-Fragments. Grundlegendes Prinzip ist der statistisch an jeder Stelle erfolgende Abbruch der Strangsynthese durch die Zugabe fluoreszenzfarbstoffmarkierter Didesoxynukleotide (ddNTPs).

Identisch einer PCR bindet ein sequenzspezifischer Primer an die denaturierte DNA, um einer Polymerase als Startpunkt für die Synthese eines komplementären Stranges unter Einbau der vier Desoxynukleotide (dATP, dTTP, dCTP, dGTP) zu dienen. Anders als bei der PCR bewirkt nun aber die limitierte Zugabe der ddNTPs einen basenspezifischen Synthesestopp für den Fall ihres Einbaus. Mittels der Fluoreszenzmarkierung können an den resultierenden Fragmenten unterschiedlicher Länge, im Anschluss an eine elektrophoretische Auftrennung, durch die Fluorographie die Position des Kettenabbruchs sichtbar gemacht werden und so auf die Sequenz geschlossen werden.

Nach Aufreinigung der DNA-Fragmente erfolgte die Sequenzanalyse mit Hilfe eines auch für die vorausgegangene PCR-Reaktion benutzten Primers. Folgender Ansatz lag dabei der Reaktion zugrunde:

$\begin{array}{ll}1 \mu \mathrm{g} & \text { Plasmid DNA } \\ \text { oder } & \\ 0,5 \mu \mathrm{g} & \text { aufgereinigtes PCR-Produkt } \\ 1 \mu \mathrm{l} & \text { spezifischer Primer (10 pmol) } \\ 4 \mu \mathrm{l} & \text { DYEnamic ET-Terminator-Mix (vom Hersteller) } \\ \text { ad } 20 \mu \mathrm{l} & \mathrm{dH}_{2} \mathrm{O}\end{array}$

Die Reaktion erfolgte nach 5 min initialer Denaturierung der DNA-Fragmente bei $95^{\circ} \mathrm{C}$ für 25 Zyklen in einem Thermocycler nach folgendem Sequenzierprogramm:

$\begin{array}{lll}\text { Denaturierung } & 95^{\circ} \mathrm{C} & 20 \mathrm{sec} \\ \text { Anlagerung } & 55^{\circ} \mathrm{C} & 30 \mathrm{sec} \\ \text { Verlängerung } & 60^{\circ} \mathrm{C} & 2 \mathrm{~min} .\end{array}$


Einem letzten Verlängerungsschritt von 10 min bei $75^{\circ} \mathrm{C}$ folgte die Aufreinigung der DNA-Fragmente in einer Sephadex-Säule, bevor diese mit Hilfe eines automatischen Sequenzierers vom Modell MegaBace1000 (Amersham Bioscience, Freiburg) ausgewertet wurden.

\subsubsection{Transfer bakterieller Nukleinsäuren auf Nylonfilter}

Um möglichst schnell und effektiv nach einer Transformation eine größere Anzahl von Bakterienkolonien auf eine Plasmidintegration hin zu überprüfen, wurde die Koloniehybridisierung eingesetzt.

Ein Optitran BA-S85 Nylonfilter wurde mit einem 9 x 9 Felder großen Quadrat beschriftet und auf eine, mit einem Antibiotikum der Bakterienresistenz entsprechende, Agarplatte gelegt. Analog wurde eine zweite Platte ohne Nylonfilter beschriftet. So konnten bis zu 81 Kolonien mit sterilen Zahnstochern erst auf dem Filter, dann in dem korrespondierenden Quadrat auf der Agarplatte ohne Filter ausgestrichen und über Nacht bei $37^{\circ} \mathrm{C}$ inkubiert werden. Am nächsten Tag wurde der Nylonfilter auf getränktem Blottingpapier wie folgt inkubiert:

$\begin{array}{lc}5 \mathrm{~min} & 10 \%(\mathrm{w} / \mathrm{v}) \mathrm{SDS} \\ 3 \mathrm{~min} & \text { Denaturierungslösung: } \\ & 0,5 \mathrm{M} \mathrm{NaOH} \\ & 1,5 \mathrm{M} \mathrm{NaCl} \\ 10 \mathrm{~min} & \text { Neutralisierungslösung: } \\ & 1,5 \mathrm{M} \mathrm{NaCl} \\ & 0,5 \mathrm{M} \mathrm{tris} / \mathrm{HCl}, \mathrm{pH} 7,4 \\ 2 \times 5 \mathrm{~min} & 2 \times \mathrm{SSC} .\end{array}$

Abschließend wurde die DNA durch Bestrahlung mit UV-Licht im UV-Stratalinker auf dem Filter fixiert. Der Filter konnte so direkt für eine Hybridisierung mittels ${ }^{32} \mathrm{P}$ radioaktiv markierter DNA-Sonden genutzt werden oder wurde luftgetrocknet bei $4^{\circ} \mathrm{C}$ gelagert. 


\subsubsection{Radioaktive Techniken}

\subsubsection{Radioaktive Markierung von Nukleinsäuren}

Mit ${ }^{32} \mathrm{P}$ radioaktiv markierte DNA-Sonden wurden für eine anschließende Koloniehybridisierung generiert. Das Verfahren wurde gemäß dem Protokoll des Herstellers mit dem Hexalabel ${ }^{\mathrm{TM}}$ DNA Labeling Kit durchgeführt.

Grundlage des Verfahrens bildet das „random priming“ nach Feinberg und Vogelstein (1983). Kurze Oligonukleotide, die mit hoher Wahrscheinlichkeit in jeder denaturierten DNA-Sequenz binden, dienen als zufälliger Startpunkt einer Polymerase für die Synthese des komplementären DNA-Stranges. Der Einbau von $\left[\alpha-{ }^{32} \mathrm{P}\right] \mathrm{dCTP}$ (Desoxycytosintriphosphat mit dem $\alpha$-ständigen Phosphorisotop 32P) bewirkt die Radioaktivität der Sonde.

Zunächst wurden etwa 30 - 50 ng der zu markierenden DNA und $10 \mu \mathrm{l} 5 \mathrm{x}$ Hexanukleotid-Puffer mit $\mathrm{dH}_{2} 0$ auf ein Gesamtvolumen von $40 \mu \mathrm{l}$ aufgefüllt und für 10 min im kochenden Wasserbad denaturiert. Nach 3 min Inkubation auf Eis wurden $3 \mu \mathrm{l}$ MixC (dNTPs ohne dCTP), $1 \mu$ Klenow Fragment sowie $3 \mu 1[\alpha-$ $\left.{ }^{32} \mathrm{P}\right] \mathrm{dCTP}$ hinzugegeben und bei $37^{\circ} \mathrm{C}$ für $10 \mathrm{~min}$ inkubiert. Unter gleicher Bedingung wurde die Synthese des komplementären Stranges nach Zugabe von $4 \mu \mathrm{l}$ dNTP-Mix weitere 5 min fortgesetzt. Das Hinzufügen von $150 \mu \mathrm{dH}_{2} 0$ beendete die Reaktion und der Ansatz konnte auf eine MicroSpin ${ }^{\mathrm{TM}}$-Aufreinigungssäule gegeben werden, um vor allem nicht eingebautes radioaktives dCTP zu entfernen. Im Anschluß an die Zentrifugation bei $800 \mathrm{x}$ g für 2 min wurde das Eluat bei $95^{\circ} \mathrm{C}$ für 10 min zur Erzeugung der einzelsträngingen Sonden denaturiert und konnte nach Abkühlung für 3 min auf Eis für die Koloniehybridisierung genutzt werden.

\subsubsection{Hybridisierung radioaktiv markierter Sonden}

Die Hybridisierung beschreibt einen Vorgang, bei dem sich an einen Einzelstrang einer Nukleinsäure ein komplementärer Nukleinsäureeinzelstrang anlagert. Sie erlaubt mit Hilfe einer zuvor markierten Sonde z. B. die spezifische Detektierung membranfixierter Nukleinsäuren. 
Vor der eigentlichen Hybridisierung wird zunächst zur Verringerung unspezifischer Bindungen der Sonde eine Prähybridisierung durchgeführt. Der Nitrocellulosefilter wurde mit 2 x SSC äquilibriert und mit der nukleinsäurebehafteten Seite nach innen in ein mit 2 x SSC gefülltes Hybridisierungsgefäß eingebracht. Die Flüssigkeit wurde dekantiert, so dass der Filter luftblasenfrei an der Wand des Reaktionsgefäßes zum Liegen kam und $10 \mathrm{ml}$ „rapid-hyb buffer“ sowie $300 \mu \mathrm{l}$ denaturierte Lachsspermien-DNA zugegeben. Die Prähybridisierung erfolgte für mindestens $2 \mathrm{~h}$ bei $65^{\circ} \mathrm{C}$.

Für die Hybridisierung wurde anschließend die mit ${ }^{32} \mathrm{P}$ radioaktiv markierte Sonde hinzugefügt und über Nacht bei $65^{\circ} \mathrm{C}$ inkubiert. Am nächsten Tag wurde die Membran für 2 x 10 min in Waschlösung I bei $65^{\circ} \mathrm{C}$ im Wasserbad geschwenkt und nachfolgend bei selbiger Temperatur in Waschlösung II inkubiert bis die Hintergrundaktivität ausreichend reduziert werden konnte. Der Filter wurde nachfolgend luftgetrocknet und in Folie laminiert. Danach mit einem Röntgenfilm in eine Autoradiographiekassette gelegt und bei $-80^{\circ} \mathrm{C}$ je nach Aktivität variierend von Stunden bis Tage exponiert. Abschließend wurde der Film in einem automatischen Entwickler gegeben und positive Klone konnten lokalisiert werden. Die während des Transfers der bakteriellen Nukleinsäure auf den Nylonfilter angelegte zweite korrespondierende Agarplatte stellte die gewünschten rekombinanten Klone zur weiteren Bearbeitung zur Verfügung.

\begin{tabular}{|c|c|}
\hline \multirow[t]{2}{*}{ Waschlösung I } & $0,2 \%(w / v)$ SDS \\
\hline & in $2 \times$ SSC \\
\hline \multirow[t]{2}{*}{ Waschlösung II } & $0,2 \%(\mathrm{w} / \mathrm{v}) \mathrm{SDS}$ \\
\hline & in $0,2 \times \mathrm{SSC}$ \\
\hline
\end{tabular}




\subsubsection{Zellkulturtechniken}

\subsubsection{Kultivierung von NIH3T3-Zellen}

Für eine Transfektion wurden NIH3T3-Zellen in der Zellkultur gehalten. Die gesamten Arbeiten mit Zellkulturen wurden in einer Umluft-Sterilbank der Firma Heareus mit sterilen Glas- oder Plastikpipetten durchgeführt.

Bei NIH3T3-Zellen handelt es sich um adhärent wachsende Mausfibroblasten, die in Gewebekulturflaschen mit $10 \mathrm{ml}$ Zellkulturmedium und $5 \% \mathrm{CO}_{2}$-Begasung bei feuchter Atmosphäre im $37^{\circ} \mathrm{C}$ warmen Brutschrank kultiviert wurden. In der Regel wurden die proliferierenden Zellen alle 3 Tage geteilt und in neue Kulturflaschen überführt. Dazu wurden nach Entnahme des verbrauchten Mediums die auf dem Boden der Flasche haftenden Zellen mit $10 \mathrm{ml}$ PBS gewaschen und anschließend mit 1,5 ml eines Trypsin/EDTA-Gemisches abgelöst. Zur Inaktivierung der Trypsin/EDTA-Lösung wurden wiederum $5 \mathrm{ml}$ Medium hinzugegeben. Jeweils $2 \mathrm{ml}$ dieser Zellsuspension wurden dann in neue Kulturflaschen überführt und mit $10 \mathrm{ml}$ Medium aufgefüllt sowie nach vorsichtigem Schwenken zur Verteilung in der Flasche im Brutschrank unter obigen Bedingungen kultiviert.

\subsubsection{Transfektion von NIH3T3-Zellen}

Als Transfektion wird das Einbringen von Fremd-DNA in Zellkulturzellen bezeichnet. Hierzu wurde die Methode der Lipofektion gewählt. Dabei werden die Plasmide mittels Liposomen in die Zielzelle gebracht. Vorteil dieser auch als transiente Transfektion bezeichneten Methode, bei der die Plasmid-DNA nicht in das Genom integriert wird, ist ein Vorliegen dieser in hoher Kopienzahl, was zu einer hohen Proteinexpression führt.

Die vorgesehenen Mausfibroblasten wurden wie in 2.2.10.1 beschrieben kultiviert, bis sie eine konfluente, zusammenhängende Schicht von etwa $80 \%$ der Fläche der Kulturflasche gebildet hatten. Für die folgende Transfektion wurde Lipofectamin 2000 Transfection-Reagenz von Invitrogen benutzt. Es wurden zwei Ansätze vorbereitet. Der erste enthielt $10 \mu \mathrm{l}$ Lipofectamin und wurde mit OptiMEM-1Medium auf $100 \mu$ l Gesamtvolumen aufgefüllt. Der zweite enthielt $3 \mu$ g Plasmid- 
DNA und wurde ebenfalls mit OptiMEM-1 auf $100 \mu$ aufgefüllt. Nach separater Inkubation beider Ansätze für 5 min bei RT wurden diese zügig in einem der Reaktionsgefäße vermischt und noch einmal für 20 min bei RT inkubiert. Während dieser Phase wurden die in DMEM kultivierten NIH3T3-Zellen mit $10 \mathrm{ml}$ PBS gewaschen sowie nach Entfernung des PBS mit $1 \mathrm{ml}$ OptiMEM-1-Medium bedeckt. Nach Ablauf der 20 minütigen Inkubationsphase wurde das Transfektionsgemisch Tropfen für Tropfen auf die Zellen in den Flaschen gegeben. Es folgte eine Inkubationsphase bei $37^{\circ} \mathrm{C}$ im Brutschrank von $3-4$ h Dauer. Nach dieser Zeit wurde das Transfektionsgemisch in der Kulturflasche gegen DMEM-Medium, das FKS und Antibiotika enthielt, ausgetauscht. Im Anschluß an eine erneute Inkubation im Brutschrank bei $37^{\circ} \mathrm{C}$ für 24 - 48 h konnten die transfizierten Zellen zur Isolierung der exprimierten Proteine herangezogen werden.

\subsubsection{Isolierung von Zellkultur-Proteinen}

Nach erfolgter Transfektion wurde die Zellkultur geerntet, mit dem Ziel die exprimierten Proteine für eine Co-Immunopräzipitation nutzbar zu machen.

Die kultivierten Zellen wurden etwa 48 h nach erfolgter Transfektion zwei Mal mit $10 \mathrm{ml}$ kaltem PBS gewaschen und anschließend mit $150 \mu \mathrm{l}$ Lysispuffer der folgenden Zusammensetzung bedeckt:

$\begin{array}{ll}50 \mathrm{mM} & \text { Tris-HCl, pH 7,5 } \\ 150 \mathrm{mM} & \mathrm{NaCl} \\ 1 \% & \mathrm{NP}-40 \\ 1 \mathrm{mM} & \text { DTT } \\ 2,5 \mathrm{mM} & \text { EDTA } \\ 1 \mu \mathrm{M} & \text { Aprotinin } \\ 1 \mu \mathrm{M} & \text { Leupeptin } \\ 1 \mathrm{mM} & \text { PMSF }\end{array}$

Daraufhin wurden das Zellmaterial mit einem sterilen Plastik-Schaber vom Boden der Kulturflasche gekratzt, in ein E-Cup überführt und unter mehrmaliger Inversion 30 min auf Eis inkubiert. Daraufhin erfolgte ein Zentrifugation des Lysats für 10 
min bei $4^{\circ} \mathrm{C}$ und Überführung der sich nun im Überstand befundenen isolierten Proteine in eine neues E-Cup. Nach Abnahme von $50 \mu \mathrm{l}$ als späteren Proteinstandart konnten die Lysate direkt verwendet oder bei $-20^{\circ} \mathrm{C}$ gelagert werden.

\subsubsection{Analyse von Fluoreszenzproteinen}

Mit für Fluoreszenzproteine codierenden Plasmiden zuvor transfizierte Zellen wurden für $48 \mathrm{~h}$ bei $37^{\circ} \mathrm{C}$ wie unter 2.2.10.1 beschrieben kultiviert. Statt Zellkulturflaschen wurden Objektträger mit zwei kleinen Zellkammern verwendet. Nach 10 min Fixierung auf dem Objektträger mittels Methanol wurden diese für 5 min in PBT inkubiert. Nach Beträufeln mit DAPI enthaltenden Vectashield Mounting ${ }^{\circledR}$ Medium, welches an DNA bindet und somit den Zellkern fluoreszieren lässt, wurden die Träger noch mit einem Deckgläschen abgedeckt. Die Ergebnisse der Transfektion konnten dann unter dem Mikroskop mit UV-Licht (Olympus BX60) sichtbar gemacht und über eine angeschlossene Digitalkamera mit entsprecheder bildbearbeitenden Software (SIS) archiviert werden.

\subsubsection{Immunfluoreszenzfärbung von NIH3T3-Zellen}

Die über Nacht auf Objekträgern gewachsenen Zellen wurden für 10 min bei RT durch eine eiskalte Methanol/Acetonmischung (Verhältnis 1:1) fixiert. Nach einmaligem Waschen in PBS wurden unspezifische Bindungsstellen durch Inkubation in Blocking-Lösung abgedeckt. Anschließend wurde der erste in PBS dilutierte Antikörper über Nacht bei $4{ }^{\circ} \mathrm{C}$ in einer feuchten Kammer hinzugefügt. Nach 4 x Waschen mit PBS/0,2 \% Tween-20 konnte mit dem zweiten Antikörper, an FITC oder Cy3 konjugiertes von der Ziege stammendes Anti-Kaninchen- oder Anti-Maus-IgG für 1 Stunde bei RT inkubiert werden. Nach 3 x Waschen mit PBS/0,2 \%1 Tween-20 wurde ein Tropfen DAPI enthaltendes Mounting Medium auf die Slides gegeben und diese mit einem Deckgläschen abgedeckt. Analog zur Analyse von Fluoreszenzproteinen konnten die Ergebnisse mit einem Olympus BX60 Mikroskop sichtbar gemacht und über digitale Bildverarbeitung archiviert werden. 


$\begin{array}{lll}\text { Blocking-Lösung: } & \text { PBS mit } \\ & 5 \% & \text { Ziegenserum } \\ 3 \% & \text { BSA } \\ 1 \mathrm{x} & \text { Roti-Block-Lösung (vom Hersteller) }\end{array}$

\subsubsection{Co-Immunopräzipitation}

Die Co-Immunopräzipitation ist eine immunologische Technik zum Interaktionsnachweis zweier Moleküle. In der Regel handelt es sich um zwei Proteine.

Gegen ein zu untersuchendes Protein (Antigen) wird ein spezifischer Antikörper dem Zelllysat hinzugefügt. Über eine vorherige Kopplung an magnetische Partikel erfolgt eine Separierung der Antikörper-Antigen-Komplexe vom restlichen Zelllysat. Putative Interaktionspartner, die an das zu untersuchende Protein binden, werden so zusammen mit diesem separiert. Anschließend kann der vermutete Interaktionspartner durch proteinchemische Techniken mit Hilfe eines nun für diesen spezifischen zweiten Antikörpers nachgewiesen und damit eine Interaktion gezeigt werden.

NIH3T3-Zellen wurden mit zwei Expressionsvektoren codierend für Proteine deren Interaktion untersucht werden sollte co-transfiziert und die Gesamtproteine nach 48 h Wachstum, wie unter 2.2.10.3 beschrieben, isoliert. Für die Immunopräzipitation mussten zuerst $100 \mu \mathrm{l}$ Dynabeads gemäß dem Protokoll des Herstellers 3 x mit 500 $\mu$ l 0,1 M Natirumphosphat-Puffer (PB) gewaschen werden. Dynabeads sind magnetische Teilchen, die über einen Magneten eine wiederholte Pelletierung erlauben und an Protein A oder G kovalent gebunden sind. Beide Proteine besitzen eine Bindungsstelle für die Fc-Region von Immunglobulinen, sie weisen aber eine unterschiedliche Affinität zu den Immunglobulinen und Subtypen verschiedener Spezies auf. Die Bindung der Dynabead-Protein-Komplexe an $5 \mu$ des ersten Antikörpers erfolgte mittels Inkubation für $1 \mathrm{~h}$ bei RT. Es wurde dann $1 \mathrm{ml}$ CrossLinking-Lösung hinzugefügt und weitere 30 min bei RT unter Bewegung inkubiert. Die Reaktion wurde durch abschließende Inkubation mit $1 \mathrm{ml}$ Tris/HCl $(\mathrm{pH}$ 7,5) für 15 min bei RT gestoppt. Nach 3 x Waschen in $500 \mu$ PB konnten die jetzt fest verbundenen Antikörper-Dynabead-Protein-Komplexe für die Immunpräzipitation 
verwandt werden. Dazu wurden diese mit $400 \mu \mathrm{l}$ Zelllysat über Nacht bei $4^{\circ} \mathrm{C}$ auf dem Schüttler inkubiert. Die mittels Magneten pelletierten, an das Antigen gebundenen Dynabead-Antikörper-Einheiten wurden 3 x mit $500 \mu \mathrm{l}$ PB gewaschen. Bevor sie als reine Antigen-Antikörper-Komplexe der SDS-PAGE zugeführt werden konnten, mussten die magnetischen Partikel durch Kochen für 10 min bei $95^{\circ} \mathrm{C}$ in $50 \mu \mathrm{l} 1 \mathrm{x}$ SDS-Auftragspuffer wieder von den Komplexen separiert werden.

Cross-Linking-Lösung: $\quad$ 0,2 M Triethanolamin, $\mathrm{pH}$ 8,0

5,4 mg Dimethylpimelimidatdihydrochlorid (DMP)

\subsubsection{Proteinchemische Techniken}

\subsubsection{SDS-Polyacrylamidgelelektrophorese (SDS-PAGE)}

Die SDS-PAGE nach Laemmli et al. (1970) ist eine Methode Proteine abhängig von ihrem molekularen Gewicht aufzutrennen. Acrylamid und Bisacrylamid bilden dabei als Polymer ein molekulares Sieb. Dies führt dazu, dass durch SDS denaturierte und mit einer negativen Ladung versehene Proteine unter Anlage einer elektrischen Spannung ein von ihrer Masse abhängiges Laufverhalten zeigen. Für alle Experimente wurden Trenngele der Firma Invitrogen mit einem Acrylamidgehalt von $12 \%$ verwendet.

Für die Elektrophorese wurde das Gel in der Elektrophoresekammer fixiert und die Kammer mit Glycin-Puffer befüllt. Die Proteinproben wurden für $10 \mathrm{~min}$ bei $95^{\circ} \mathrm{C}$ zusammen mit SDS-Auftragspuffer gekocht, bevor $20 \mu$ l der präparierten Proben und $10 \mu \mathrm{l}$ des Protein-Markers in die Geltaschen geladen wurden. Zur Separierung der Proteine lief das Gel zu Beginn mit 70 Volt und wurde nach einer halben Stunde auf 120 Volt hoch reguliert. Anschließend konnten die im Gel aufgetrennten Proteine zur Immundetektion mittels eines Western-Blots verwandt werden.

$$
\begin{aligned}
& \text { Glycin-Puffer: } \quad \begin{array}{l}
1,44 \%(w / v) \text { Glycin } \\
0,3 \%(w / v) \text { Tris-Base } \\
0,1 \%(w / v) \text { SDS }
\end{array}
\end{aligned}
$$




$\begin{array}{ll}2 \text { x SDS-Auftragspuffer: } & 4,8 \%(\mathrm{w} / \mathrm{v}) \text { SDS } \\ & 20 \%(\mathrm{v} / \mathrm{v}) \text { Glycerin } \\ & 10 \%(\mathrm{v} / \mathrm{v}) \text { 2-Mercaptoethanol } \\ & 0,1 \%(\mathrm{w} / \mathrm{v}) \text { Bromphenolblau } \\ & 100 \mathrm{mM} \text { Tris/HCl } \mathrm{pH} 7,8\end{array}$

\title{
2.2.14.2 Western-Blot (Semi-dry Blot)
}

Nach Separation in einem SDS-Polyacrylamidgel können Proteine auf eine Membran transferiert und dadurch immobilisiert werden. Anschliessend kann ein Nachweis der Proteine mittels eines spezifischen Antikörpers geführt werden. Als geeignete Trägermatrix dient eine PVDF-Membran, auf der die Proteine durch lipophile Wechselwirkungen binden. Der elektrophoretische Transfer erfolgt hier durch eine senkrecht zur ursprünglichen Laufrichtung angelegten Spannung. Zunächst wurden die Elektrodenplatten des Blotters mit $\mathrm{dH}_{2} \mathrm{O}$ angefeuchtet und 9 Whatman GB004 Blottingpapiere auf die Größe eines Gels passend geschnitten. 3 Papiere wurden in Anode-I-Puffer getränkt und 3 wurden in Anode-II-Puffer getränkt, bevor sie auf die Anode des Semidry-Blotters gelegt wurden. Auf diese folgten die mit Methanol angefeuchtete PVDF-Membran und das Trenngel. Als abschließende Schicht wurden 3 in Kathoden-Puffer getränkte Papiere aufgelegt und mit der Graphit-Kathodenplatte die Kammer geschlossen. Luftblasen wurden vorher vorsichtig mit einem Handroller herausgewalzt. Nach einem Transfer von $1 \mathrm{~h}$ mit 3,5 mA pro $\mathrm{cm}^{2}$ Membranfläche konnte die PVDF-Membran der immunologischen Detektion zugeführt werden.

\author{
Anode-I-Puffer: $\quad$ 0,3 M Tris/HCl, $\mathrm{pH} \mathrm{10,4}$ \\ $20 \%$ (v/v) Methanol \\ Anode-II-Puffer: 25 mM Tris/HCl, $\mathrm{pH}$ 10,4 \\ $20 \%$ (v/v) Methanol
}




$\begin{array}{ll}\text { Kathoden-Puffer: } & 40 \mathrm{mM} \text { \&-Aminocapronsäure } \\ & 25 \mathrm{mM} \text { Tris/HCl, pH 9,4 } \\ & 20 \% \text { Methanol }\end{array}$

\subsubsection{Immunologische Detektion membrangebundener Proteine}

Prinzip der Nachweismethode ist eine Antikörper vermittelte Enzymreaktion. Nach Bindung eines spezifischen Antikörpers an das membranfixierte Zielprotein, erfolgt die Visualisierung des Antigen-Antikörper-Komplexes mittels eines zweiten Enzym-gekoppelten Antikörpers unter Zusatz eines Farbstoffgemisches.

Nach erfolgtem Western-Blot wurde der Proteinmarker von der PVDF-Membran abgetrennt. Zur Untersuchung mit verschieden Antikörpern wurde die Membran in Streifen getrennt. Dann wurden die unspezifischen Proteinbindungsstellen der Membran mit Block-Puffer unter Schwenken auf dem Schüttler für $1 \mathrm{~h}$ bei RT abgesättigt. Luftblasenfrei eingeschweißt in einem Plastikbeutel wurde die Membran bei $4^{\circ} \mathrm{C}$ über Nacht zusammen mit dem ersten Antikörper in einer Verdünnung von 1:500 unter Bewegung inkubiert. Am nächsten Tag wurde 3 x 5 min mit Wasch-Puffer gewaschen um ungebundene Antikörper zu entfernen. Es folgte die Inkubation mit dem in $10 \mathrm{ml}$ Wasch-Puffer auf 1:10000 verdünnten zweiten Antikörper für $1 \mathrm{~h}$ bei RT auf einem Schüttler. Dieser IgG-Antikörper ist mit dem Enzym alkalische Phosphatase gekoppelt. Die Membran wurde erneut für 3 x 5 min in Wasch-Puffer bewegt, sowie anschließend einmalig 5 min mit P3-Puffer. Für die Farbreaktion wurde das Substrat-Chromogengemisch, bestehend aus $45 \mu \mathrm{l}$ NBT- und $35 \mu$ l BCIP-Lösung in $10 \mathrm{ml}$ P3-Puffer, zusammen mit der Membran in einem luftblasenfrei eingeschweißten Plastikbeutel inkubiert. Die Farbstoffe bilden die Substrate für die alkalische Phosphatase, die katalytische Aktivität bewirkt eine Reduzierung des NBT und eine Abspaltung der Phosphatgruppe des BCIP, beides bewirkt einen bandenförmigen, blauvioletten Niederschlag der vorher schwach gelben Entwicklerflüßigkeit an den Stellen der Membran, an denen der zweite Antikörper gebunden ist. Die Farbreaktion wurde nach 2 - 3 min durch kurzes Waschen in $\mathrm{dH}_{2} \mathrm{O}$ gestoppt und die Membran auf Filterpapier an der Luft getrocknet. Zur Konservierung wurde diese abschließend in einen Plastikbeutel eingeschweißt und konnte mit dem Proteinmarker verglichen werden. 


\begin{tabular}{|c|c|c|}
\hline \multirow[t]{3}{*}{10 x Wasch-Stammlösung: } & $1,4 \mathrm{M}$ & $\mathrm{NaCl}$ \\
\hline & $100 \mathrm{mM}$ & Tris/HCl, pH 7,5 \\
\hline & $0,5 \%(\mathrm{v} / \mathrm{v})$ & Tween 20 \\
\hline \multirow[t]{2}{*}{ Block-Puffer: } & $5 \%(w / v)$ & Magermilchpulver in \\
\hline & \multicolumn{2}{|c|}{$1 \mathrm{x}$ Wasch-Stammlösung } \\
\hline \multirow[t]{2}{*}{ Wasch-Puffer: } & $2 \%(w / v)$ & Magermilchpulver in \\
\hline & \multicolumn{2}{|c|}{$1 \mathrm{x}$ Wasch-Stammlösung } \\
\hline \multirow[t]{3}{*}{ P3-Puffer: } & $100 \mathrm{mM}$ & $\mathrm{NaCl}$ \\
\hline & $50 \mathrm{mM}$ & $\mathrm{MgCl}_{2}$ \\
\hline & $100 \mathrm{mM}$ & Tris/HCl, pH 9,5 \\
\hline \multirow[t]{2}{*}{ NBT-Lösung: } & $75 \mathrm{mg} / \mathrm{ml}$ & NBT \\
\hline & $70 \%$ & Dimethylformamid (DMF) \\
\hline BCIP-Lösung: & $50 \mathrm{mg} / \mathrm{ml}$ & BCIP in \\
\hline
\end{tabular}




\section{$3 \quad$ Ergebnisse}

\subsection{Expressionsanalyse von Cops5 in der Maus durch RT-PCR}

Zunächst sollte die organspezifische Expression von Cops5 untersucht werden. Dazu wurde Gesamt-RNA von Organen aus Wildtyp-Mäusen mittels RT-PCR auf eine Cops5-Expression untersucht. Mutationen im für Spastin codierenden SPG4Gen, dem putativen COPS5-Interaktionspartner, führen vorzugsweise zu einer gestörten Funktion der langer -Motorneuronenfunktion. Daher bildete RNA aus neuronalem Gewebe einen Schwerpunkt der Analyse. Zusätzlich wurden embryonale RNA's verwendet. Im Rahmen einer OneStep RT-PCR-Reaktion wurde die RNA in cDNA umgeschrieben und mit den Primern F1 bzw. R3 die Cops5cDNA anschließend amplifiziert. Der R3 Primer wurde in den Übergang von Exon 2 zu Exon 3 gelegt (Abb. 3.1), um eine Kontamination des Ansatzes mit DNA ausschließen zu können. Das gewählte Primerpaar umfasste so einen Bereich von insgesamt $334 \mathrm{bp}$.

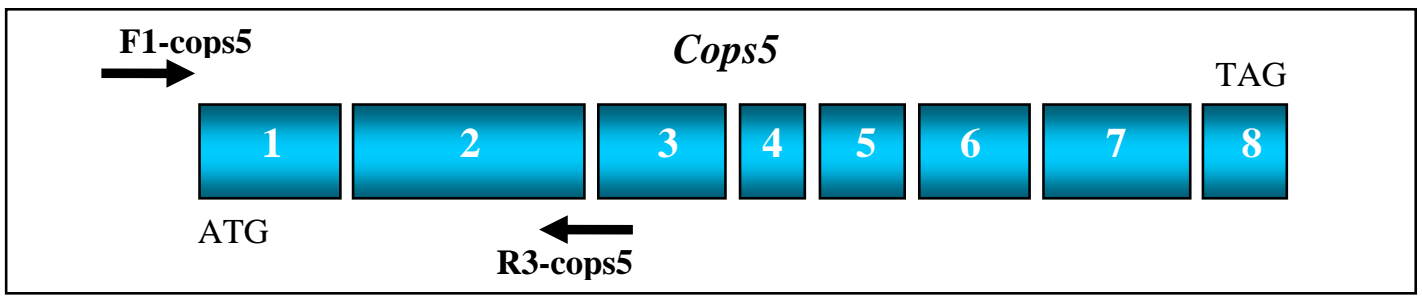

Abb. 3.1: Schematische Darstellung der murinen Cops5-Exonstruktur. Das vom Cops5-Gen abgeleitete Transkript besteht aus 8 Exons. Die für die RT-PCR verwendeten Primer F1-cops5 und R3-cops5 lokalisieren in der 5’UTR bzw. im Übergang von Exon 2 zu 3. Das erwartete Fragment hat damit eine Größe von 334 bp.

Zur Kontrolle wurde ein 438 bp GAPDH-Fragment amplifiziert. Die PCR-Produkte wurden in einem 0,8 \%igen Agarosegel ektrophoretisch aufgetrennt (Abb. 3.2). In allen untersuchten murinen Organen wurde das erwartete 334 bp große Cops5Fragment nachgewiesen. Gleiches galt für die untersuchten Embryonalstadien. Insbesondere auch in den aufgrund des oben genannten Sachverhaltes ausgewählten 
neuronalen Geweben - Hippokampus, Kleinhirn, Rückenmark und Resthirn konnten die Fragmente und damit die Expression von Cops5 nachgewiesen werden. Vor dem Hintergrund der somit demonstrierten Expression in vivo konnten nachfolgend Experimente zur subzellulären Cops5-Lokalisation und einer etwaigen Interaktion mit Spastin begonnen werden.
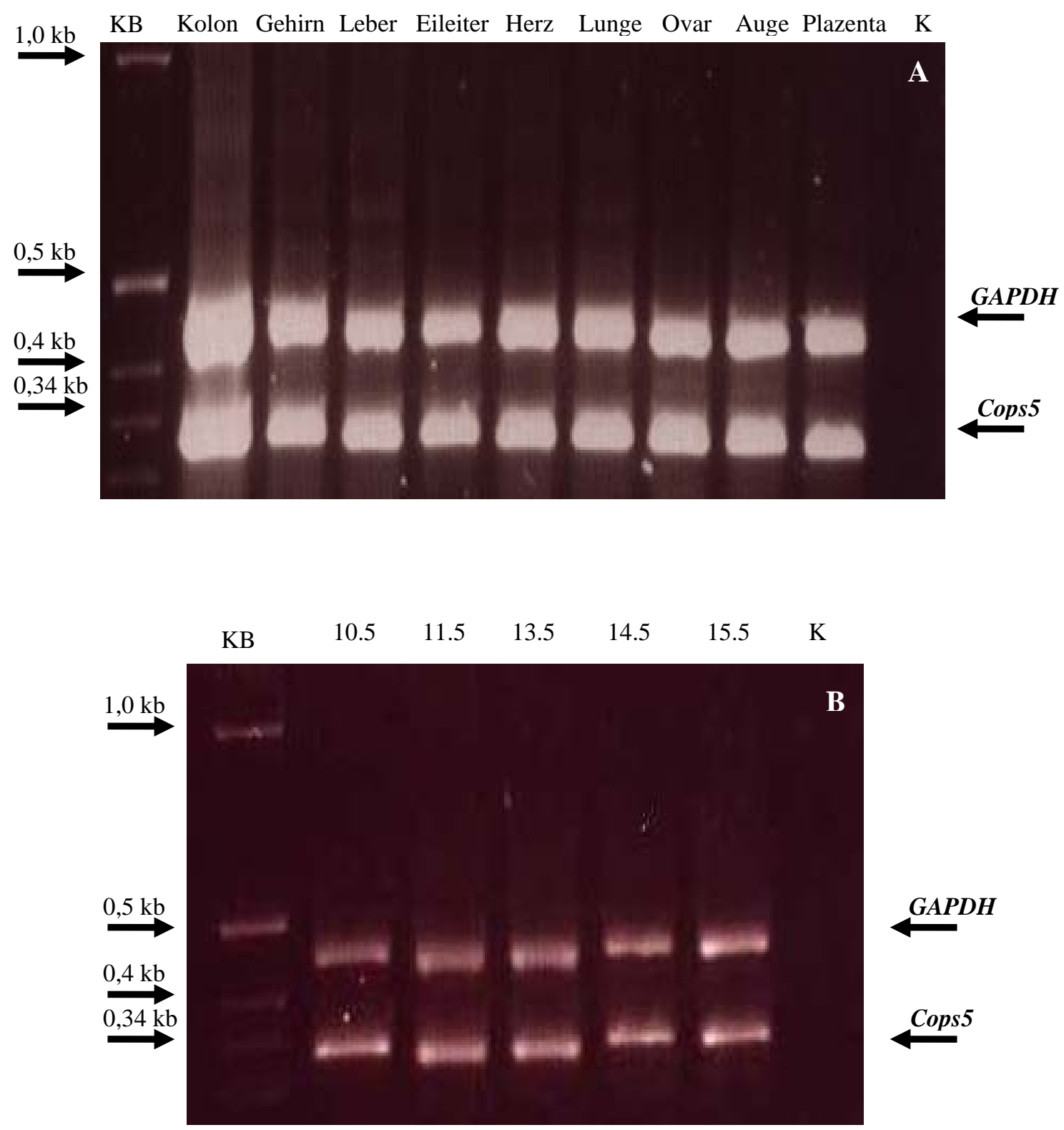


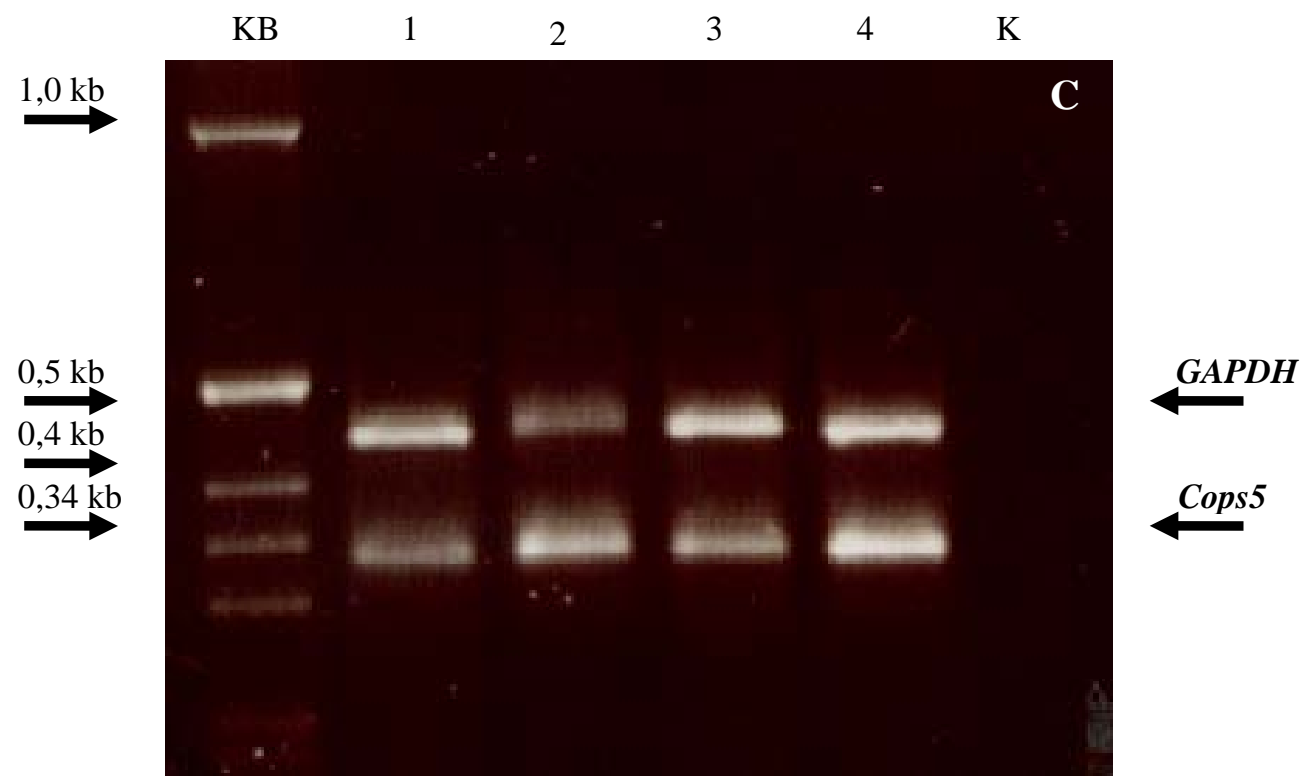

Abb. 3.2: RT-PCR-Produkt von Cops5 in murinen Organen und embryonalem Gewebe aufgetrennt in 0,8 \%igem Agarosegel. $\mathrm{KB}=1 \mathrm{~Kb}$-Längenstandard, $\mathrm{K}=0$-Kontrolle, GAPDH = Positiv-Kontrolle A: Analyse von RNA aus adultem Gewebe. B: RNA aus murinen embryonalen Geweben zu verschiedenen Tagen der embryonalen Entwicklung. C: RNA aus neuronalem Gewebe. 1 = Hippokampus, 2 = Kleinhirn, 3 = Rückenmark, 4 = Resthirn

\subsection{Charakterisierung von Cops5 als Interaktionspartner des Spastins in NIH3T3-Zellen}

Im Rahmen einer Diplomarbeit wurden mittels des Yeast-Two-Hybrid (Y2H)Systems vier Proteine als putative Interaktionspartner des vom SPG4-Gen kodierten Spastins identifiziert. Eines dieser interagierenden Proteine ist COPS5. In vitro Experimente sollten daher nun COPS5 auf subzellulärer Ebene charakterisieren und die im Y2H-System gefundene Interaktion zwischen COPS5 und Spastin in Säugerzellen unabhängig verifizieren. Da es mit Ausnahme des pDsRed-N1-Vektors (3.2.2.3) nicht gelang, humane COPS5-Fusionskonstrukte zu generieren, wurden für diese Arbeit murine Cops5-Fusionskonstrukte untersucht. Mensch und Maus zeigen jedoch auf Peptidebene eine nahezu 100 \%ige Übereinstimmung ihrer Sequenz (siehe Anhang). 


\subsubsection{Synthese der kodierenden Sequenz von Cops5 und Klonierung in den pGEM-T-Easy-Vektor}

Ausgehend von muriner Gesamt-RNA (Gehirn) konnte mittels OneStep RT-PCR und darauf folgender Nested-PCR die kodierende Sequenz von Cops5 synthetisiert werden. Die dabei verwendeten Primer befanden sich jeweils in der untranslatierten Region der RNA und cDNA-Sequenz. Das generierte PCR-Produkt wurde anschließend gelelektrophoretisch überprüft (Abb. 3.3).

\begin{tabular}{|r|cc|c|}
\hline$\stackrel{\text { F2-cops5 }}{\longrightarrow}$ & $\mathbf{1 0 8 4}$ bp & \multicolumn{2}{c|}{ TAG } \\
\hline UTR & Cops5 & UTR \\
\hline
\end{tabular}

Abbildung 3.3: Schematische Darstellung der 1084 bp großen kodierenden Sequenz von Cops5. UTR $=$ Untranslatierte Region. ATG $=$ Startcodon. TAG $=$ Stoppcodon. Für die RT-PCR-Reaktion wurden die Primer F1-cops5 und R1-cops5 verwendet (hier nicht mit dargestellt), für die anschließende Amplifikation mittels Nested-PCR die Primer F2-cops5 und R2-cops5.

Die Cops5-Sequenz wurde nach Aufreinigung mit dem pGEM-T-Easy-Vektor ligiert und der Ligationsansatz in kompetente DH5 $\alpha$-Zellen transformiert. Eine Minipräparation erlaubte größere Mengen dieser erzeugten Cops5-pGEM-T-EasyKonstrukte zu gewinnen, um deren Sequenz und Orientierung zu kontrollieren. Abschließend wurde ein so verifizierter Klon für weitere Experimente ausgewählt und zusätzlich als Glycerinstock konserviert.

\subsubsection{Generierung von Cops5-Konstrukten mithilfe bakterieller Expressionssysteme}

Zur Charakterisierung des Cops5-Proteins und seiner möglichen Interaktion mit Spastin wurde die Cops5-cDNA aus dem Cops5-pGEM-T-Easy-Konstrukt (3.2.1) in andere Vektoren kloniert, die eine Expression in Säugetierzellen ermöglichen 
sollten. Die gewählten Vektoren besaßen zusätzlich so genannte „tags“ (kurze Erkennungssequenzen) am C-terminalen oder N-terminalen Ende. Je nach Art erlaubten diese Erkennungssequenzen mittels UV-Anregung eine direkte Detektierung des exprimierten Proteins oder eine indirekte bei zusätzlicher Unterstützung durch einen Antikörper. Vorraussetzung war jeweils die Klonierung der Cops5-Sequenz in den korrekten Leserahmen.

\subsubsection{Klonierung von Cops5 aus pGEM-T-Easy in pQM-NTag/A-Intron}

Der pQM-NTag/A-Intron-Vektor verfügt über eine E2-Erkennungssequenz, die eine Detektion des exprimierten Proteins durch einen monoklonalen Maus-Anti-E2-IgGAntikörper ermöglichen sollte. Das generierte Cops5-E2-Konstrukt steht unter Kontrolle des CMV-Promotors. Es enthält die E2-Erkennungssequenz an seinem Nterminalen Ende im korrekten Leserahmen. Das Startcodon wurde zuvor aus der sonst vollständigen Cops5-cDNA entfernt (Abb. 3.4).

Ausgangspunkt der Generierung des Cops5-Inserts für den Vektor war eine PCR mit DNA des Cops5-pGEM-T-Easy-Konstrukts (3.2.1). Die dabei zur Synthese benutzten Primer verfügten über eine HindIII- bzw. eine BglIIRestriktionsschnittstelle, so dass eine spätere Klonierung in die korrespondierenden Restriktionsseiten des pQM-Vektors erfolgen konnte. Das erwartete Fragment wurde aufgereinigt und mit dem pGEM-T-Easy-Vektor ligiert. Zur Erzeugung einer größeren Menge dieser Konstrukte wurden diese in kompetenta DH5 -Zellen transformiert. Eine Minipräparation ermöglichte die Sequenzierung zur Kontrolle des Cops5-pGEM-T-Easy-Konstrukts mit den nun vorhandenen Restriktionsschnittstellen. Ein geeigneter Klon wurde daraufhin mit den Restriktionsendonukleasen HindIII bzw. BglII geschnitten und gelelektrophoretisch aufgetrennt, sowie das Insert aus dem Agarosegel isoliert.

Zur Herstellung des pQM-Vektors wurden Escherichia coli (E. coli) Zellen mit dem Vektor transformiert und nach Minipräparation ebenfalls mit HindIII und BglII restringiert. Nach gelelektrophoretischer Auftrennung konnte der jetzt linearisierte Vektor aus dem Agarose-Gel extrahiert werden.

Das aufgereinigte Cops5-Insert und der aufgereinigte pQM-NTag/A-Intron-Vektor wurden ligiert und der Ligationsansatz in kompetente Zellen transformiert. Durch 
Koloniehybridisierung konnte schnell und effektiv eine größere Anzahl von Bakterienkolonien auf Plasmidintegration überprüft und Klone identifiziert werden, bei denen eine Klonierung der Cops5-cDNA in den pQM-Vektor erfolgreich war. Die Plasmid-DNA der rekombinanten Klone musste nach einer Minipräparation daraufhin noch durch Sequenzierung auf den richtigen Leserahmen und Basenaustausche getestet werden. Von einem als geeignet getesteten Klon wurde Endotoxin-freie Plasmid-DNA gewonnen, die für Interaktionsstudien von Cops5 und Spastin in NIH3T3-Zellen genutzt werden konnte.

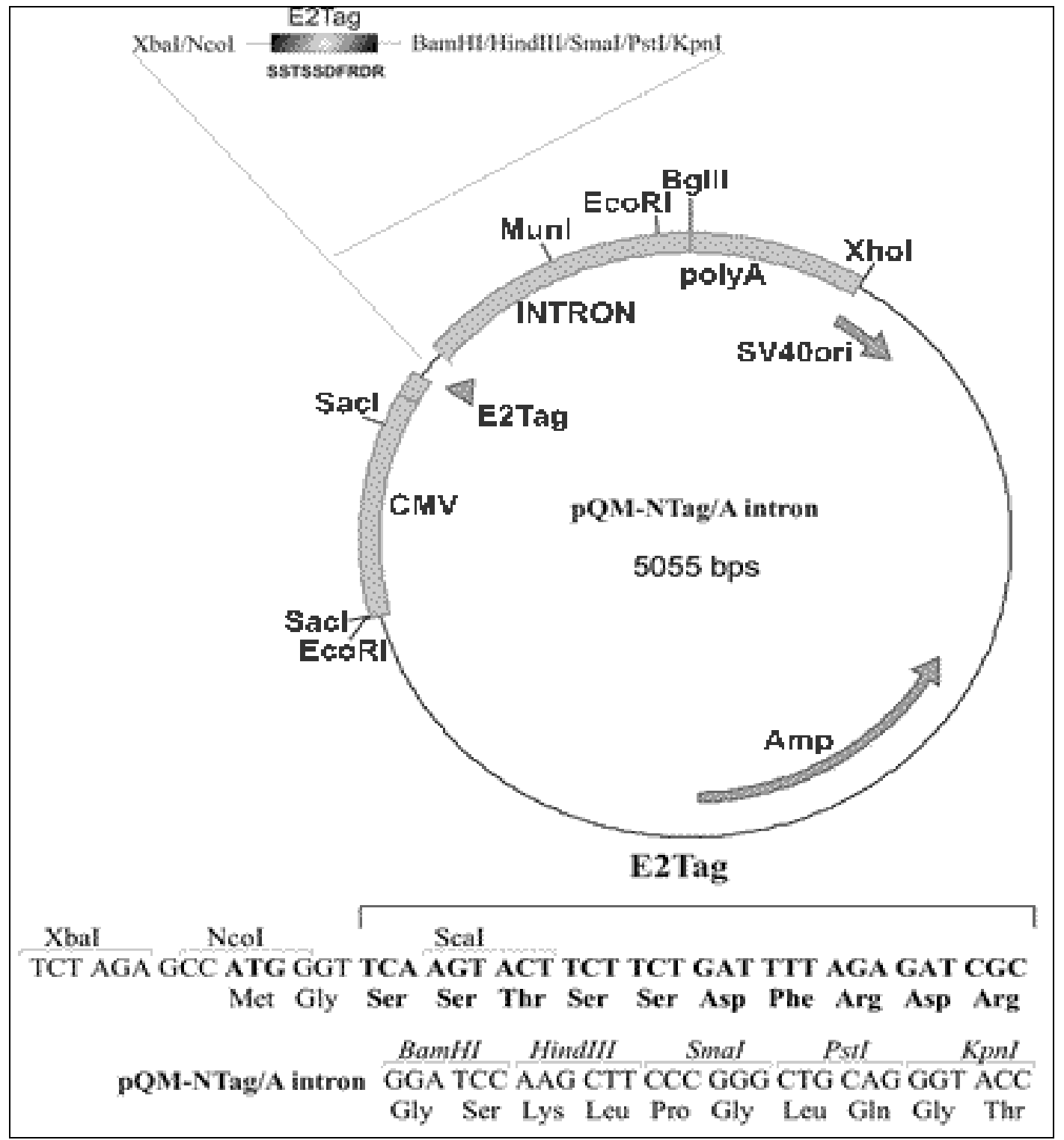

A 


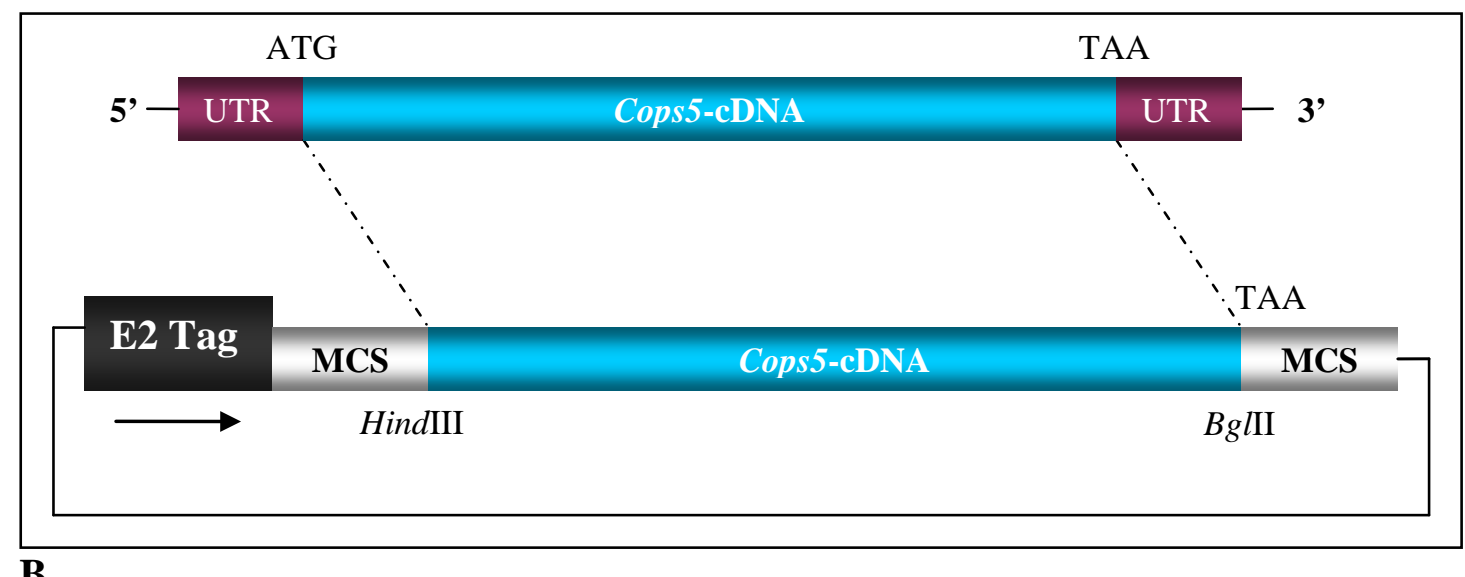

Abb. 3.4: Klonierung von Cops5 in pQM-NTag/A-Intron. A: Vektorkarte des pQM-NTag/AIntron-Vektors mit Restriktionsschnittstellen und Position des E2-Epitops (abcam 2009). B: Schematische Darstellung des generierten Cops5-E2-Konstrukts mit N-terminaler E2Erkennungssequenz. Das 1008 bp große Cops5-Insert wurde über HindIII- und BglII-Schnittstellen in den Vektor ligiert.

\subsubsection{Klonierung von Cops5 aus pGEM-T-Easy in pEGFP-C1}

Der pEGFP-C1-Vektor verfügt über die EGFP-Erkennungssequenz. Diese erlaubt als Fluorophor eine Antikörper-unabhängige Lokalisation des exprimierten Fusionsproteins unter UV-Anregung. Das generierte Cops5-EGFP-Konstrukt steht unter Kontrolle des CMV-Promotors und enthält das EGFP-Polypeptid an seinem N-terminalen Ende. Das Startcodon wurde zuvor aus der sonst vollständigen kodierenden Cops5-cDNA entfernt (Abb. 3.5).

Unter Verwendung von Primern mit Restriktionsschnittstellen für HindIII bzw. BglII wurde die Cops5-cDNA eines Cops5-pGEM-T-Easy-Konstrukts (3.2.1) amplifiziert. Die gewählte HindIII-Restriktionsschnittstelle erlaubte eine spätere Subklonierung in die korrespondierende HindIII-Schnittstelle des pEGFP-C1Vektors. Die BglII-Schnittstelle konnte hingegen aufgrund der resultierenden kompatiblen Enden durch Restriktion mit dem überhängenden Ende der BamHISchnittstelle des Vektors ligiert werden. Nach Aufreinigung der amplifizierten Cops5-Inserts wurden diese mit pGEM-T-Easy-Vektoren ligiert und in kompetente DH5 $\alpha$-Zellen transformiert. Die Minipräparation erlaubte die Gewinnung von DNA der neuen Cops5-pGEM-T-Easy-Konstrukte. Ein für die neuen Schnittstellen positiver Klon wurde mit den Restriktionsendonukleasen HindIII und BglII 
restringiert. Die präparative Gelektrophorese diente der Auftrennung und Isolierung der gewonnenen Plasmid-Inserts.

Der pEGFP-C1-Vektor wurde ebenfalls in kompetente E. coli Zellen transformiert und nach Gewinnung der Plasmid-DNA im analytischen Maßstab mit den geeigneten Restriktionsendonukleasen HindIII und BamHI behandelt. Der linearisierte Vektor wurde analog den Inserts nach elektrophoretischer Auftrennung aus dem Agarosegel extrahiert. Cops5-Insert und pEGFP-C1-Vektor wurden aufgereinigt und ligiert, sowie in DH5 $\alpha$-Zellen transformiert. Mittels Koloniehybridsierung wurde auf eine erfolgreiche Klonierung gescannt. Mehrere rekombinante Klone wurden nach Plasmidgewinnung im analytischen Maßstab abschließend durch Sequenzierung auf den richtigen Leserahmen und die korrekte Sequenz gestestet. Für Co-Lokalisationsstudien von Cops5 mit Spastin in der Zellkultur wurde ein so getesteter Klon ausgewählt und Endotoxin-freie PlasmidDNA gewonnen.

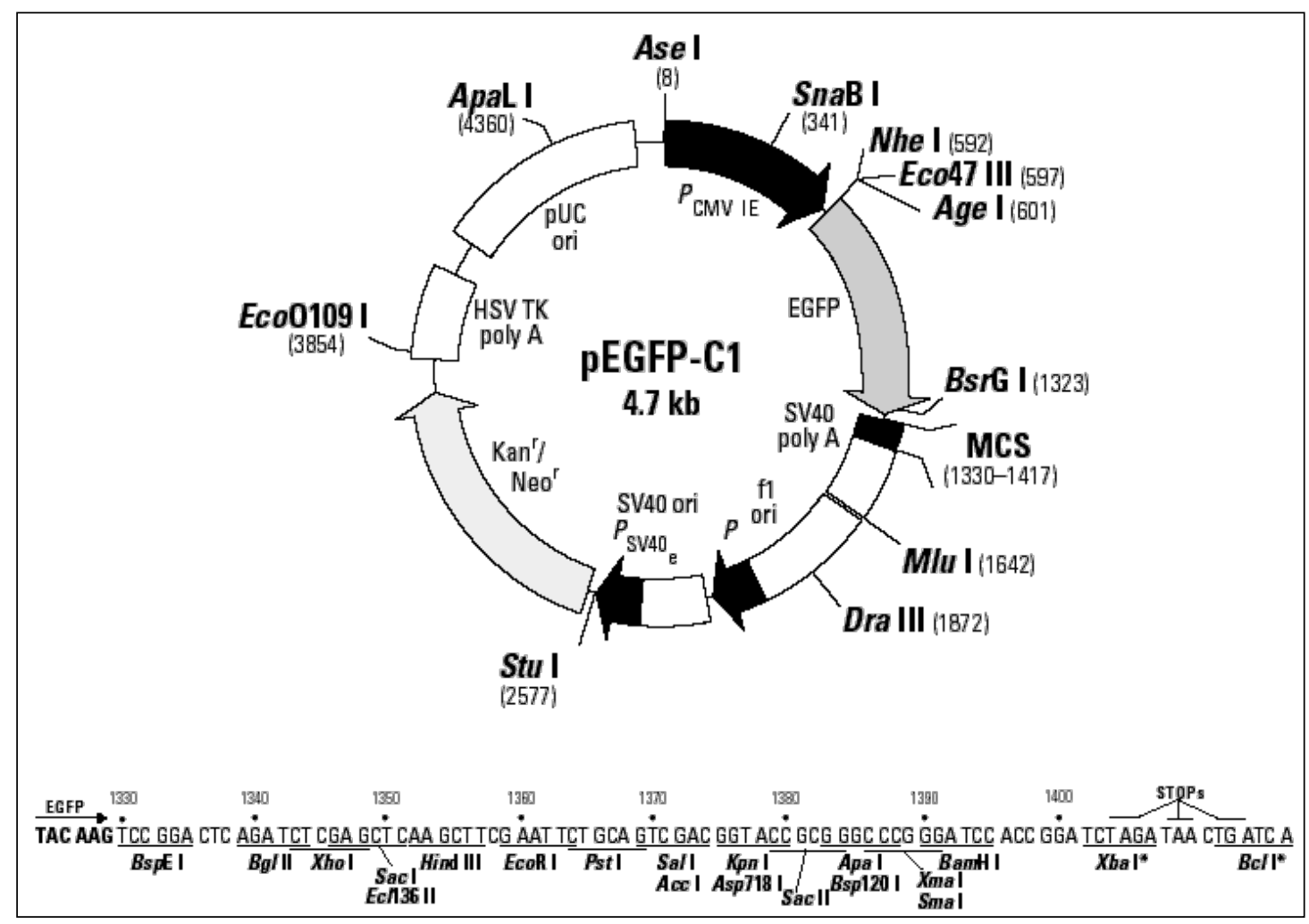




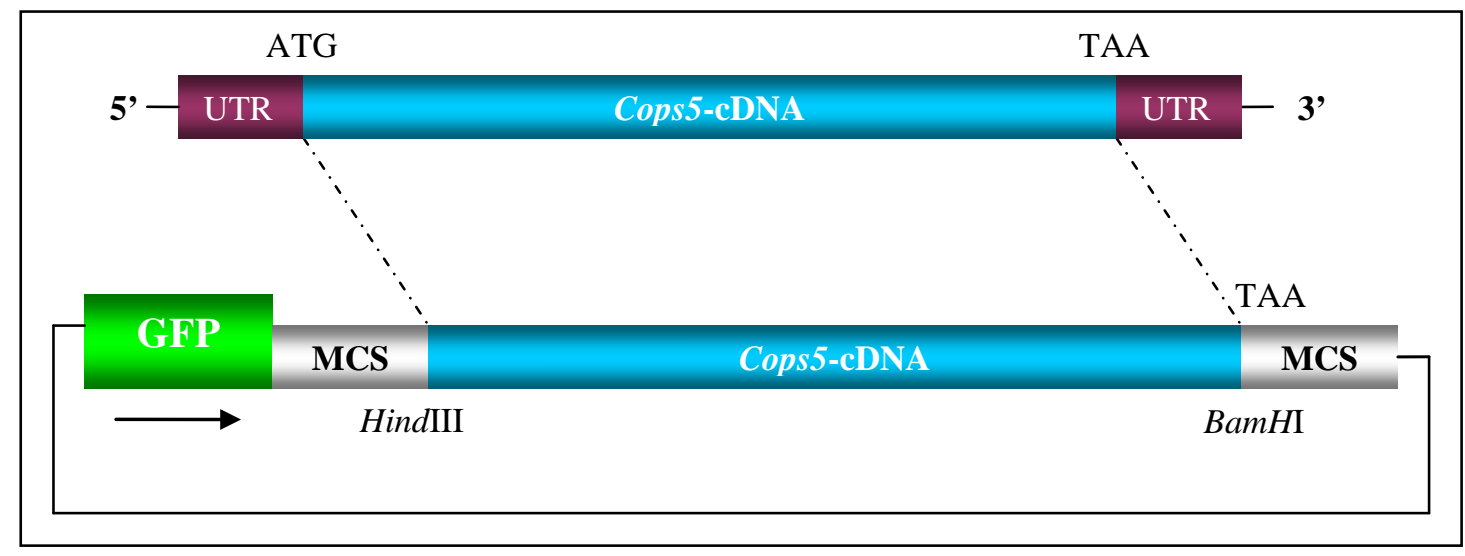

B

Abb. 3.5: Klonierung von Cops5 in pEGFP-C1. A: Vektorkarte des pEGFP-C1-Vektors mit Restriktionsschnittstellen und Position des EGFP-Epitops (ClonTech 2002). B: Schematische Darstellung des generierten Cops5-EGFP-Konstrukts mit N-terminalem EGFP-Polypeptid. Das 1008 bp große Cops5-Insert wurde über HindIII- und BamHI-Schnittstellen in den Vektor ligiert.

\subsubsection{Klonierung von COPS5 aus pGEM-T-Easy in pDsRed2-N1}

Der pDsRed2-N1-Vektor enthält als Erkennungssequenz die codierende Sequenz für ein Fluorophor. Nach Klonierung der COPS5-cDNA in den Vektor konnte das rot fluoreszierende Fusionsprotein durch optische Anregung nachgewiesen werden. Das entstandene Konstrukt umfasste die gesamte kodierende COPS5-cDNA, kloniert in den korrekten Leserahmen, und trug die Erkennungssequenz C-terminal. Das COPS5-Stopcodon wurde, um einen vorzeitigen Translationsabbruch und die Expression zweier getrennter Proteine zu vermeiden, entfernt (Abb. 3.6).

Um die COPS5-Sequenz in den pDsRed2-Vektor klonieren zu können, wurde COPS5-pGEM-T-Easy-Plasmid-DNA (3.2.1) mit Primern, die eine HindIII- bzw. BamHI-Restriktionsschnittstelle enthielten, amplifiziert. Nach Aufreinigung wurde das Fragment mit pGEM-T-Easy-Vektoren ligiert und in E. coli Zellen transformiert. Einer Isolierung von COPS5-cDNA schloss sich die enzymatische Spaltung mit HindIII bzw. BamHI an. Die Ansätze wurden elektrophoretisch aufgetrennt und die Inserts aus dem Agarosegel eluiert.

Analog dem Vorgehen mit der COPS5-Sequenz wurde der pDsRed2-N1-Vektor nach Vervielfältigung in $\alpha$ DH5 -Zellen und Plasmidgewinnung mittels 
Restriktionsendonukleasen gespalten. Durch Gelextraktion wurde der linearisierte Vektor im Anschluss an die Gelelektrophorese aus dem Trennmedium isoliert.

Die aufgereinigten COPS5-Inserts wurden in den Transfer-Vektor ligiert und mittels Transformation in kompetente DH5a-Zellen eingebracht. Positive Klone wurden durch Koloniehybridiserung selektiert und deren Plasmid-DNA isoliert. Die abschließende Sequenzierung erlaubte die Kontrolle der Basenfolge und des korrekten Leserahmens. Ein so getesteter Klon mit COPS5-Red-Konstrukt wurde für die Isolierung Endotoxin-freier Plasmid-DNA ausgewählt und für CoLokalisationsexperimente mit Spastin in Säugerzellen verwandt.

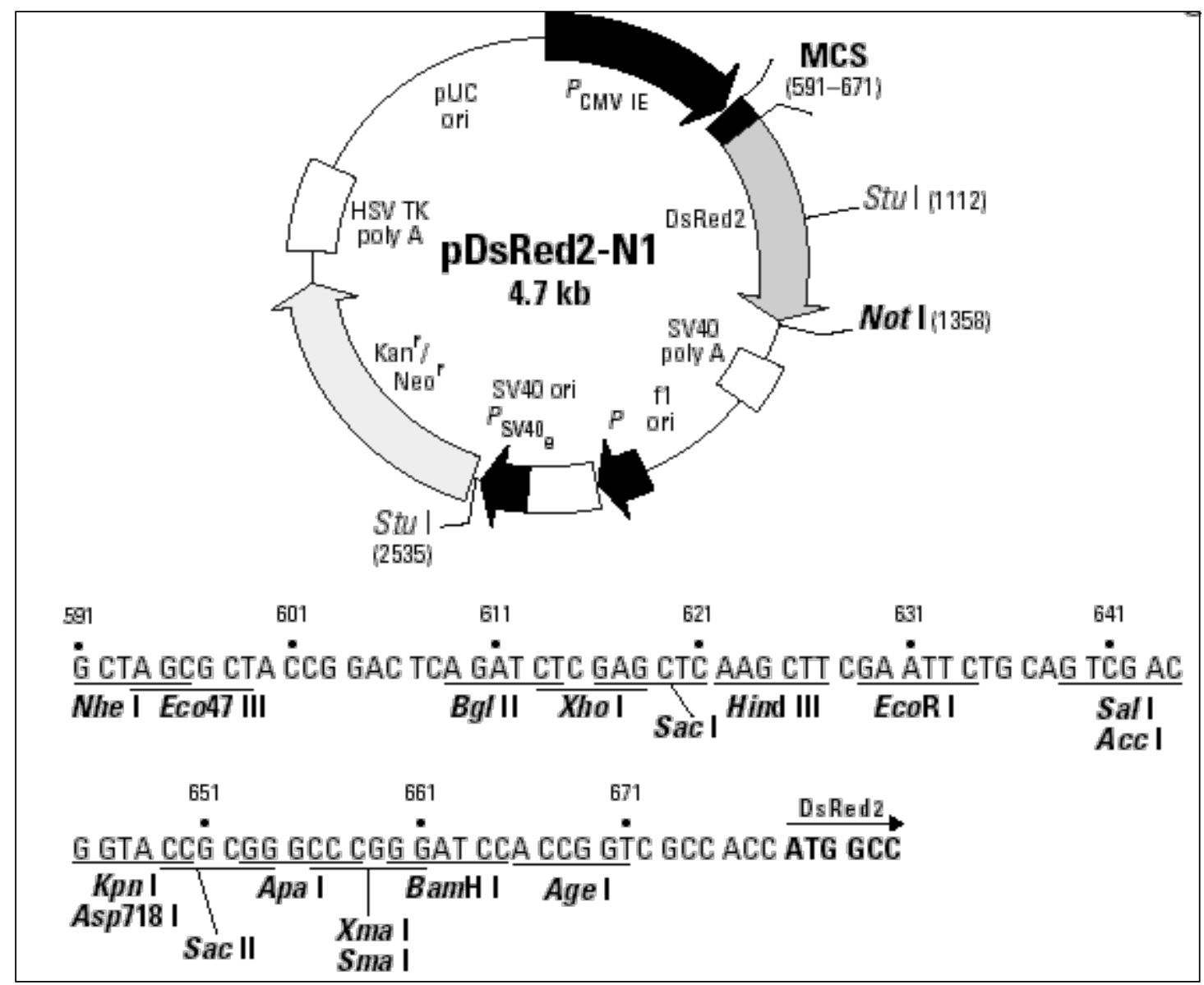




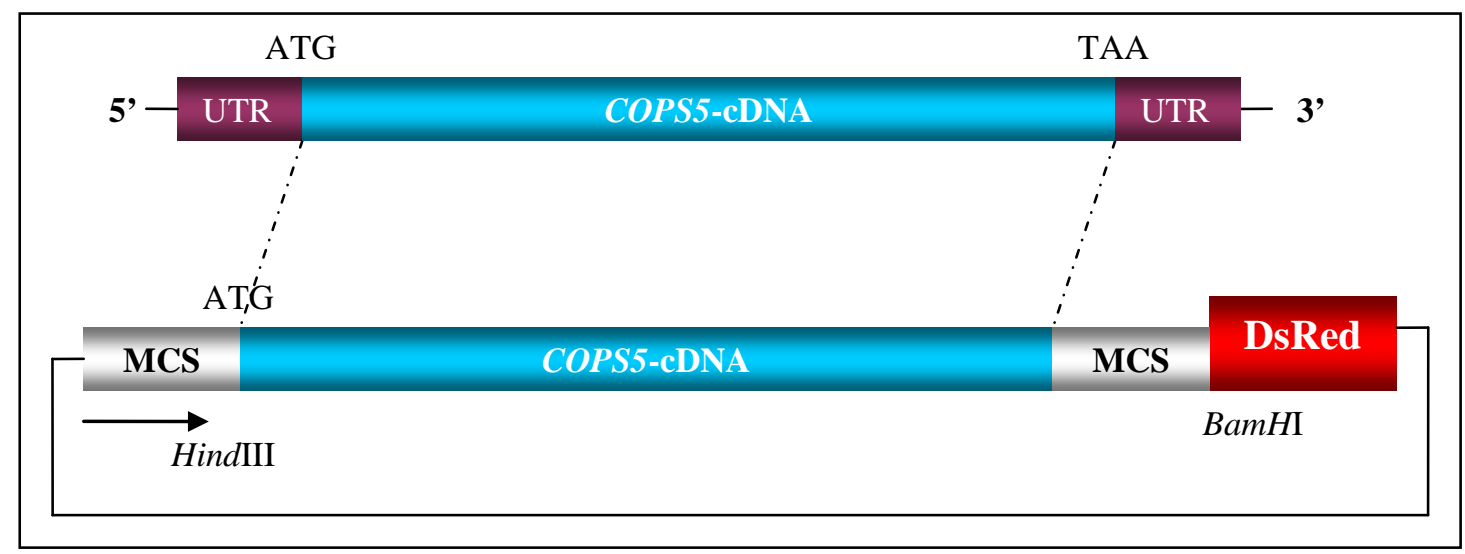

B

Abb. 3.6: Klonierung von COPS5 in pDsRed2-N1. A: Vektorkarte des pDsRed2-N1-Vektors mit Restriktionsschnittstellen (Clontech 2003). B: Schematische Darstellung des generierten COPS5Red-Konstrukts mit C-terminaler Red-Erkennungssequenz. Das 1008 bp große COPS5-Insert wurde über HindIII- und BamHI-Schnittstellen in den Vektor ligiert.

\subsubsection{Generierung von Spastin-Konstrukten mithilfe bakterieller Expressionssysteme}

Im Y2H war die Isoform II des humanen Spastins verwendet wurden. Bei dieser Analyse war COPS5 als möglicher Interaktionspartner identifiziert worden. In der weiteren Arbeit wurde ebenfalls die Isoform II des Spastins (65kDa) verwendet. Wenn im Folgenden SPG4 genannt wird, handelt es sich um diese Form der Polypeptidsequenz ohne die Bereiche, die durch das Exon 4 kodiert werden.

Im Rahmen dieser Arbeit wurden ferner zur Expression von Spastin in Säugerzellen die Vektoren pCS2-3 und pEGFP-C1 eingesetzt. Der zuerst genannte Vektor besitzt eine c-myc-Erkennungssequenz. Diese ermöglicht die Detektierung des Expressionsproteins durch einen monoklonalen Kaninchen-Anti-Myc-Antikörper. Der pEGFP-C1-Vektor enthält hingegen eine EGFP-Erkennungssequenz und erlaubt so eine Antikörper-unabhängige Detektierung.

Die SPG4-cDNA war in die EcoRI-Restriktionsschnittstelle des pEGFP-C1-Vektors kloniert worden. Die Klonierung in den pCS2-3-Vektor war ebenfalls über die EcoRI-Schnittstelle des Vektors erfolgt. Das unter dem CMV-Promotor stehende SPG4-EGFP-Konstrukt enthielt den Tag C-terminal des Inserts. Dieses musste zur erfolgreichen Expression des Fusionsproteins in den korrekten Leserahmen 
eingefügt werden. Das unter einem CMV-Promotor stehende SPG4-c-mycKonstrukt enthielt den Tag hingegen N-terminal des Inserts und wurde ebenfalls in den passenden Leserahmen kloniert. Beide Konstrukte wurden durch enzymatische Spaltung getestet und für die weiteren Experimente in der Zellkultur DNA Endotoxin-frei isoliert.

\subsubsection{Subzelluläre Lokalisation des Cops5-Proteins in NIH3T3-Zellen mittels direkter Fluoreszenzanalyse}

Zur Charakterisierung der subzellulären Lokalisation von Cops5 in Säugetierzellen wurden NIH3T3-Zellen mit dem Cops5-EGFP-Fusionskonstrukt (3.2.2.2) transfiziert und unter dem Fluoreszenzmikroskop untersucht (Abb. 3.7).

Herangezogene NIH3T3-Zellen wurden mit $1 \mu \mathrm{g}$ Cops5-EGFP-Plasmiden transfiziert. Nach 48 h Kultivierung wurden die Zellen mit Methanol auf dem Objektträger fixiert und mit DAPI behandelt. Diese Behandlung erlaubt es, den Zellkern mittels DAPI-Filter des Mikroskops zu erkennen. Die anschließende fluoreszenzmikroskopische Untersuchung zeigte, dass Cops5-Fusionsprotein überwiegend vesikulär im Zytoplasma der transfizierten NIH3T3-Zellen lokalisiert. Der grün fluoreszierende EGFP-Anhang des Konstrukts verdeutlicht darüber hinaus ein vorwiegend perinukleäres Verteilungsmuster der zytoplasmatischen Expression des Cops5-EGFP-Fusionskonstrukts. 

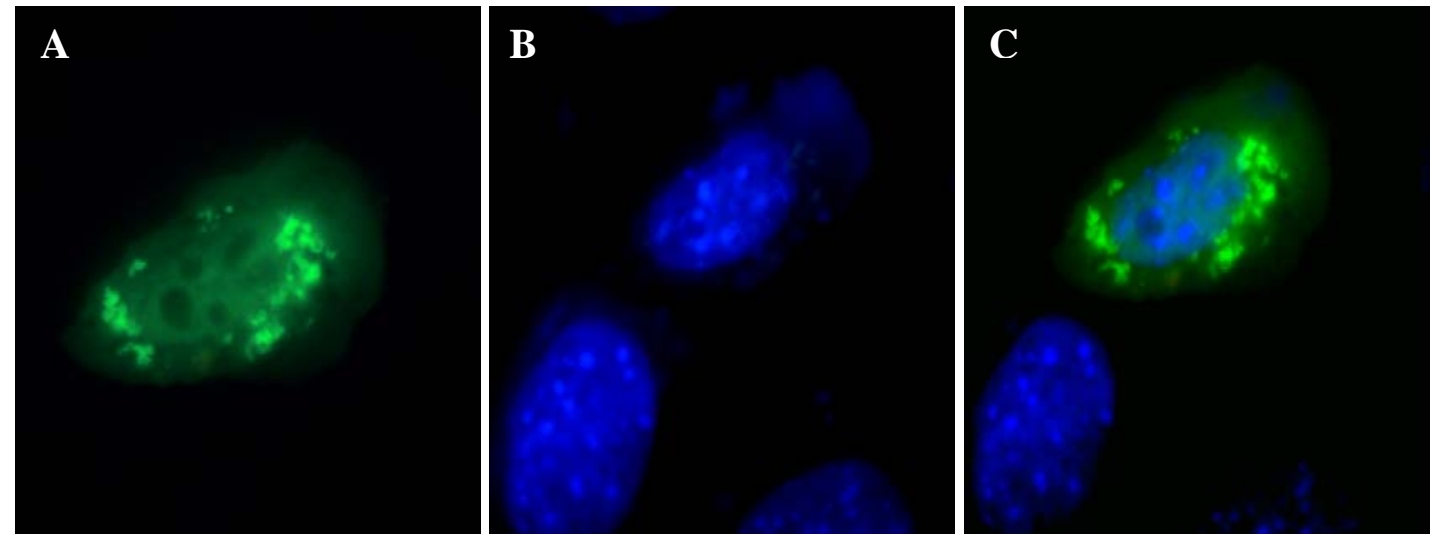

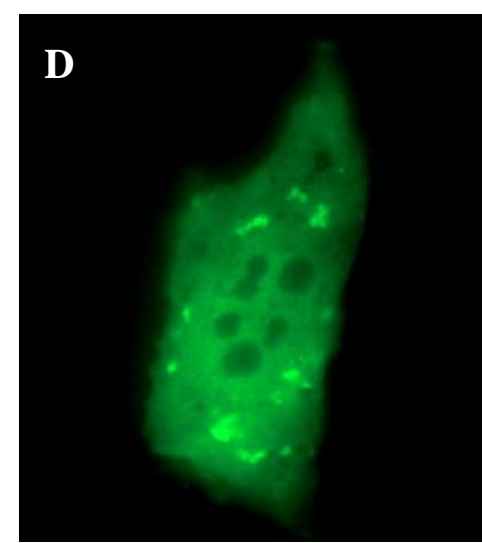

Cops5-EGFP

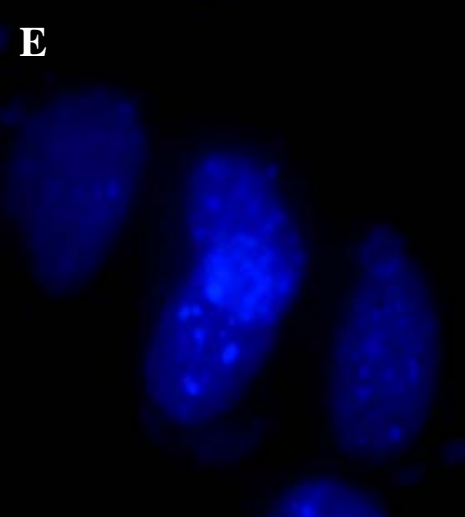

DAPI

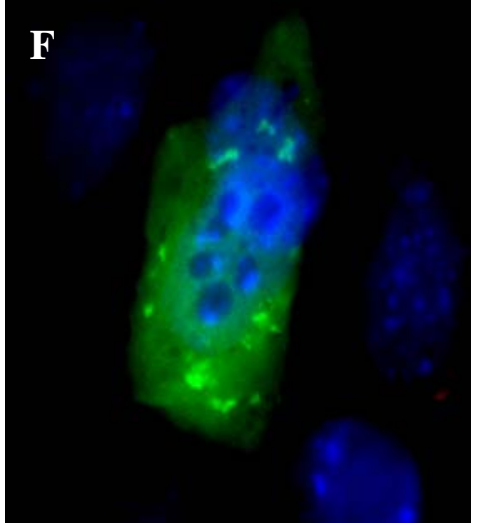

Overlay

Abb. 3.7: Fluoreszenzmikroskopische Untersuchung der subzellulären Lokalisation von Cops5 in NIH3T3-Zellen. Filter: FITC $=450-490 \mathrm{~nm}$ für Cops5-EGFP-Fusionsproteine (grünes Signal), DAPI $=355-360 \mathrm{~nm}$ für DAPI gefärbte Nuklei (blaues Signal). A,D: Lokalisation des Cops5EGFP-Fusionsproteins im Zytoplasma der NIH3T3-Zellen, 600fache Vergrößerung. B,E: Anfärbung der nukleären DNA, 600fache Vergrößerung. C,F: Digitale Übereinanderlagerung von FITC- (A + D) und DAPI-Signalen (B + E), 600fache Vergrößerung.

\subsubsection{Subzelluläre Lokalisation des Spastin-Proteins in NIH3T3-Zellen mittels immunzytochemischer Fluoreszenzanalyse}

Um die subzelluläre Lokalisation des Spastins in Säugetierzellen zu charakterisieren, wurden NIH3T3-Zellen mit einem SPG4-c-myc-Konstrukt (3.2.3) transfiziert und nach Immunfärbung unter dem Fluoreszenzmikroskop analysiert (Abb. 3.8).

NIH3T3-Zellen wurden auf einem Zweikammerobjekträger kultiviert und mit 1 ug Plasmid-DNA des SPG4-c-myc-Fusionskonstrukts transfiziert. Nach 48 h Wachstum wurden die Zellen mit Methanol auf dem Objektträger fixiert. Zur 
Lokalisationsuntersuchung war eine immunzytochemische Markierung der c-mycErkennungssequenz notwendig, daher wurden die Zellen mit monoklonalem Kaninchen-Anti-Myc-IgG und wiederum gegen dies gerichtetem Ziege-AntiKaninchen-IgG-Cy3-Konjugat immunfluoreszenzgefärbt. Nach Zugabe des primären und sekundären Antikörpers sowie DAPI-Behandlung konnten die entstandenen Immunkomplexe fluoreszenzmikroskopisch sichtbar gemacht und analysiert werden. Die Untersuchung zeigte, vermittelt durch den rot fluoreszierenden sekundären Antikörper, eine großflächige zytoplasmatische und vesikuläre Lokalisation des Spastins in den transfizierten NIH3T3-Zellen.
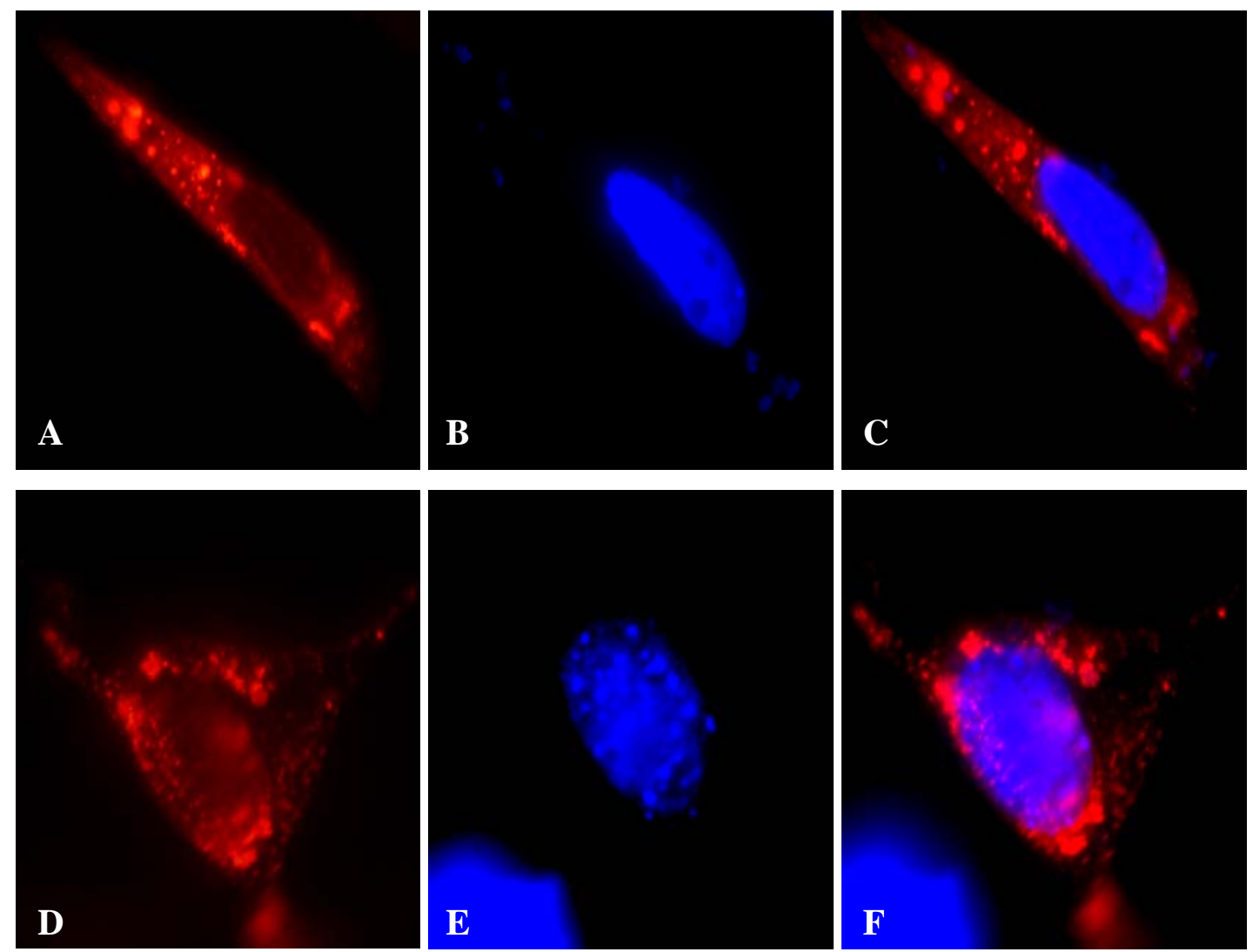

SPG4-c-myc

DAPI

Overlay

Abb. 3.8: Immunfluoreszenzmikroskopische Untersuchung der subzellulären Lokalisation von Spastin in NIH3T3-Zellen. Filter: TRITC = 552 - $570 \mathrm{~nm}$ für SPG4-c-myc-Fusionsproteine (rotes Signal), DAPI = 355 - 360 nm für DAPI gefärbte Nuklei (blaues Signal). A,D: Lokalisation des SPG4-c-myc-Fusionsproteins im Zytoplasma der NIH3T3-Zellen, 600fache Vergrößerung. B,E: Anfärbung der nukleären DNA, 600fache Vergrößerung. C,F: Digitale Übereinanderlagerung von TRITC- (A + D) und DAPI-Signalen (B + E), 600fache Vergrößerung. 


\subsubsection{Interaktionsstudien}

Nach Charakterisierung der subzellulären Lokalisation von Cops5 (3.2.4) und Spastin (3.2.5) in NIH3T3-Zellen sollte die putative Interaktion der beiden Proteine in Säugetierzellen mittels zweier biochemischer Experimente untersucht werden. Um die durch YH2-Versuche in vitro gezeigte Interaktion zu verifizieren, sollte diese zunächst durch Co-Lokalisationsstudien untersucht und anschließend durch eine Co-Immunopräzipitation bestätigt werden.

\subsubsection{Co-Lokalisation von Cops5 und Spastin in NIH3T3-Zellen mittels direkter und immunzytochemischer Fluoreszenzanalyse}

Die subzelluläre Co-Lokalisation von Cops5 und Spastin wurde sowohl mittels direkter als auch mittels immunzytochemischer Fluoreszenz überprüft. Die jeweils C-terminale bzw. N-terminale Lokalisation der mit den Proteinen fusionierten Erkennungssequenzen beinhaltete jedoch die Möglichkeit einer Co-Lokalisation, die letztlich nur auf Interaktion dieser Sequenzen beruhte. Zusätzlich sollte untersucht werden, ob die jeweilige Lage der Erkennungssequenz am C-terminalen oder Nterminalen Ende des Cops5 oder Spastin einen Einfluss auf deren subzelluläre Lokalisation hat (Abb. 3.9 und 3.10). Um diese Aspekte unwahrscheinlich werden zu lassen, wurde eine doppelte Studie durchgeführt. NIH3T3-Zellen wurden zum einen mit einem COPS5-Red- (3.2.2.3) und einem SPG4-EGFP-Konstrukt (3.2.3) co-transfiziert. In einer zweiten Studie wurde die Co-Transfektion hingegen mit einem Cops5-E2- (3.2.2.1) und einem SPG4-c-myc-Konstrukt (3.2.3) durchgeführt. Für die erste Studie wurden NIH3T3-Zellen auf einem Zweikammerobjektträger kultiviert und sowohl mit $1 \mu \mathrm{g}$ Plasmid-DNA des COPS5-Red-Konstrukts als auch des SPG4-EGFP-Konstrukts co-transfiziert. Nach 48 h konnten diese auf dem Objektträger fixiert und analysiert werden. Die Untersuchung zeigte durch die unterschiedlichen Filter für FITC, TRITC und DAPI eine über das gesamte Zytoplasma verteilte vesikuläre Lokalisation der rot fluoreszierenden COPS5- und grün fluoreszierenden Spastin-Fusionsproteine. Das Expressionsmuster des COPS5 ist dabei großenteils überlappend zu dem des Spastins, was auf eine mögliche CoLokalisation beider Fusionsproteine hindeutet. 


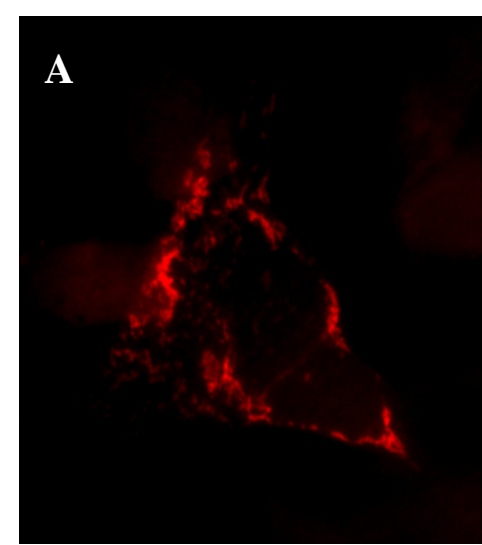

COPS5-Red

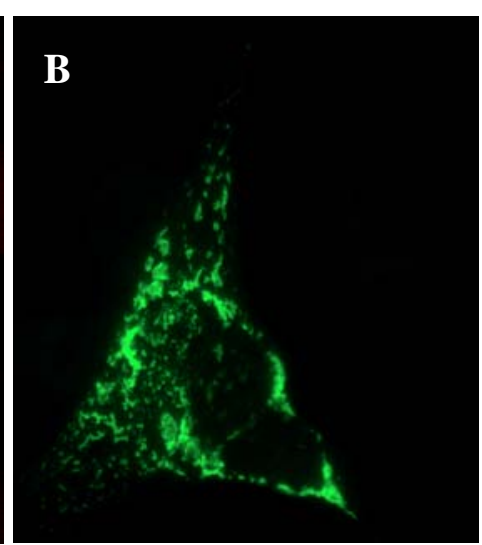

Spastin-EGFP

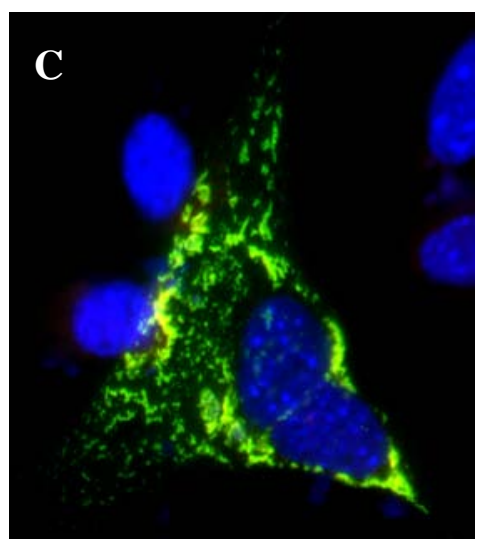

Overlay

Abb. 3.9: Fluoreszenzmikroskopische Untersuchung der subzellulären Co-Lokalisation von COPS5 mit Spastin in NIH3T3-Zellen. Filter: TRITC = 546 nm für COPS5-Red-Fusionsproteine (rotes Signal), FITC = $450-490$ nm für Spastin-EGFP-Fusionsproteine (grünes Signal), DAPI = 355 - 360 nm für DAPI-gefärbte Nuklei (blaues Signal) A: Lokalisation des COPS5-Fusionsproteins im Zytoplasma der NIH3T3-Zellen, 600fache Vergrößerung. B Lokalisation des Spastin-Fusionsproteins im Zytoplasma der NIH3T3-Zellen, 600fache Vergrößerung. C: Digitale Übereinanderlagerung der Signale mit Co-Lokalisation von COPS5 und Spastin, 600fache Vergrößerung.

Die zweite Co-Lokalisationsstudie erfolgte mit durch Cops5-E2- und SPG4-c-mycKonstrukte transfizierten Zellen. Die subzelluläre Lokalisation musste daher immunfluoreszenzmikroskopisch untersucht werden. Zur Detektierung mussten für die E2- und c-myc-Erkennungssequenz spezifische Antikörper verwendet werden. Der E2-Antikörper konnte anschließend durch einen FITC-konjugierten zweiten Antikörper, der Myc-Antikörper durch einen Cy3-konjugierten Antikörper unter dem Mikroskop visualisiert werden. Um eine gleichzeitige Präzipitation beider primärer Antikörper durch den sekundären Antikörper zu vermeiden, wurde ein Maus-Antikörperpaar (Maus-Anti-E2-IgG und Ziege-Anti-Maus-IgG-FITC) und ein Kaninchen-Antikörperpaar gewählt (Kaninchen-Anti-Myc-IgG und Ziege-AntiKaninchen-IgG-Cy3). Die nukleäre DNA wurde wieder durch DAPI sichtbar gemacht. Die so $48 \mathrm{~h}$ nach Co-Transfektion und Kultivierung behandelten Zellen zeigten ebenfalls das vesikuläre Verteilungsmuster der Cops5- und SpastinFusionsproteine im Zytoplasma der Zellen. Analog der Transfektion mit den Fluorophorfusionsproteinen der ersten Co-Lokalisationsstudie deutet auch hier das großteils überlappende Expressionsmuster auf eine Interaktion beider Proteine. 


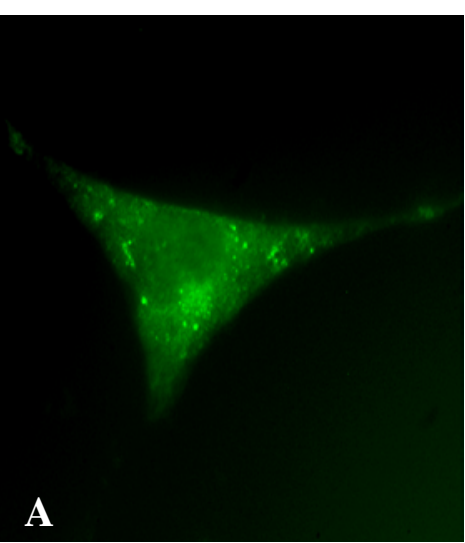

Cops5-E2

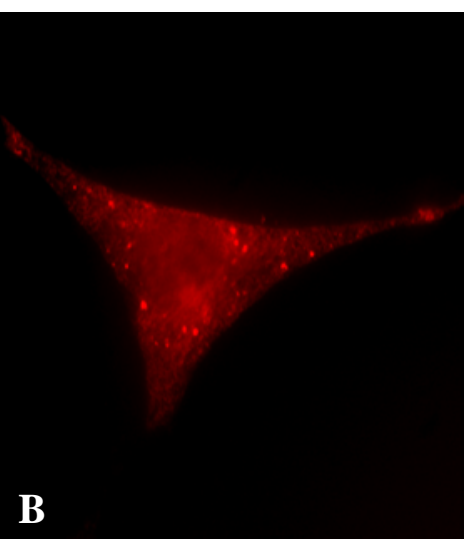

Spastin-c-myc

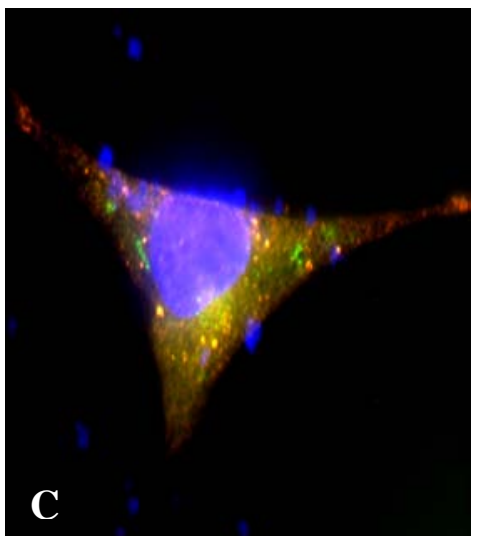

Overlay

Abb. 3.10: Immunfluoreszenzmikroskopische Untersuchung der subzellulären Co-Lokalisation von Cpos5 mit Spastin in NIH3T3-Zellen. Filter: FITC = 450 - $490 \mathrm{~nm}$ für Cops5-Fusionsproteine (grünes Signal), TRITC $=552-570 \mathrm{~nm}$ für Spastin-c-myc-Fusionsproteine (rotes Signal), DAPI = 355 - $360 \mathrm{~nm}$ für DAPI gefärbte Nuklei (blaues Signal). A: Lokalisation des Cops5-E2Fusionsproteins im Zytoplasma der NIH3T3-Zellen, 600fache Vergrößerung. B Lokalisation des Spastin-c-myc-Fusionsproteins im Zytoplasma der NIH3T3-Zellen, 600fache Vergrößerung. C: Digitale Übereinanderlagerung der Signale mit Co-Lokalisation von Cops5-E2-Fusionsprotein und Spastin-c-myc-Fusionsprotein, 600fache Vergrößerung.

\subsubsection{Co-Immunopräzipitation von Cops5 und Spastin nach Isolierung aus NIH3T3-Zellen}

Nach Demonstration der Co-Lokalisation von Cops5 und Spastin sollte mittels CoImmunopräzipitation die putative Interaktion beider Proteine in Säugetierzellen verifiziert werden. Dazu wurden die generierten Fusionsproteine Cops5-E2 (3.2.2.1) und Spastin-c-myc (3.2.3) in einem gemeinsamen Ansatz verwand. Das Prinzip bestand in der Isolierung eines Fusionsproteins mit Hilfe eines an magnetische Partikel gekoppelten Antikörpers aus dem Gesamtproteinextrakt (Abb. 3.11), der aus co-transfizierten NIH3T3-Zellen gewonnen wurde. Der mitisolierte putative Interaktionspartner konnte dann in einem weiteren Schritt durch einen zweiten gegen ihn gerichteten Antikörper nachgewiesen und visualisiert werden. 


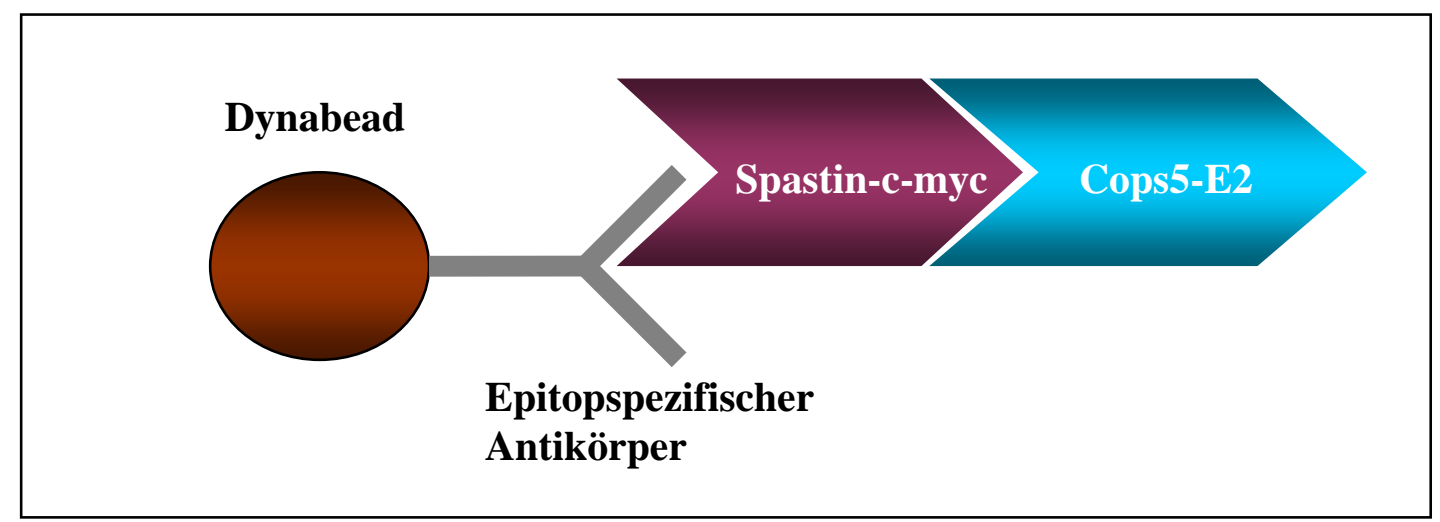

\section{Abb. 3.11: Schematische Darstellung der Co-Immunopräzipitation.}

Das Fusionsprotein wird durch sein Epitop mittels eines spezifischen, an einen magnetischen Partikel gekoppelten Antikörper präzipitiert. Im Falle einer Interaktion mit dem zweiten Fusionsprotein wird dieses mit präzipitiert und kann durch einen zweiten Antikörper anschließend visualisiert werden.

Kultivierte NIH3T3-Zellen wurden in Zellkulturflaschen mit jeweils $3 \mu \mathrm{g}$ DNA der pQM-NTag/A-Intron-Cops5- und pCS2-3-SPG4-Vektoren co-transfiziert und nach $48 \mathrm{~h}$ die Proteine extrahiert. Anschließend erfolgte die eigentliche CoImmunopräzipitation. Die pelletierten Fusionsprotein-Antikörperkomplexe wurden durch die SDS-PAGE aufgetrennt und konnten nach einem Western-Blot membrangebunden immunologisch detektiert werden. Die eingesetzten Konstrukte Cops5-E2 und SPG4-c-myc enthielten eine Sequenz für die antikörperspezifischen Epitope E2 bzw. c-myc. Mit einem monoklonalen Maus-Anti-E2-Antikörper wurde zuerst Cops5 präzipitiert und anschließend auf der Membran Spastin mittels Kaninchen-Anti-Myc-Antikörper in Verbindung mit monoklonalem Ziege-AntiKaninchen-IgG-Alkalische-Phosphatase-Konjugat detektiert (Abb. 3.12). Der so angefärbte Komplex hatte die erwartete Größe von 68 kDa. Das Ergebnis bestätigt die Interaktion von Cops5 mit Spastin in NIH3T3-Zellen. 


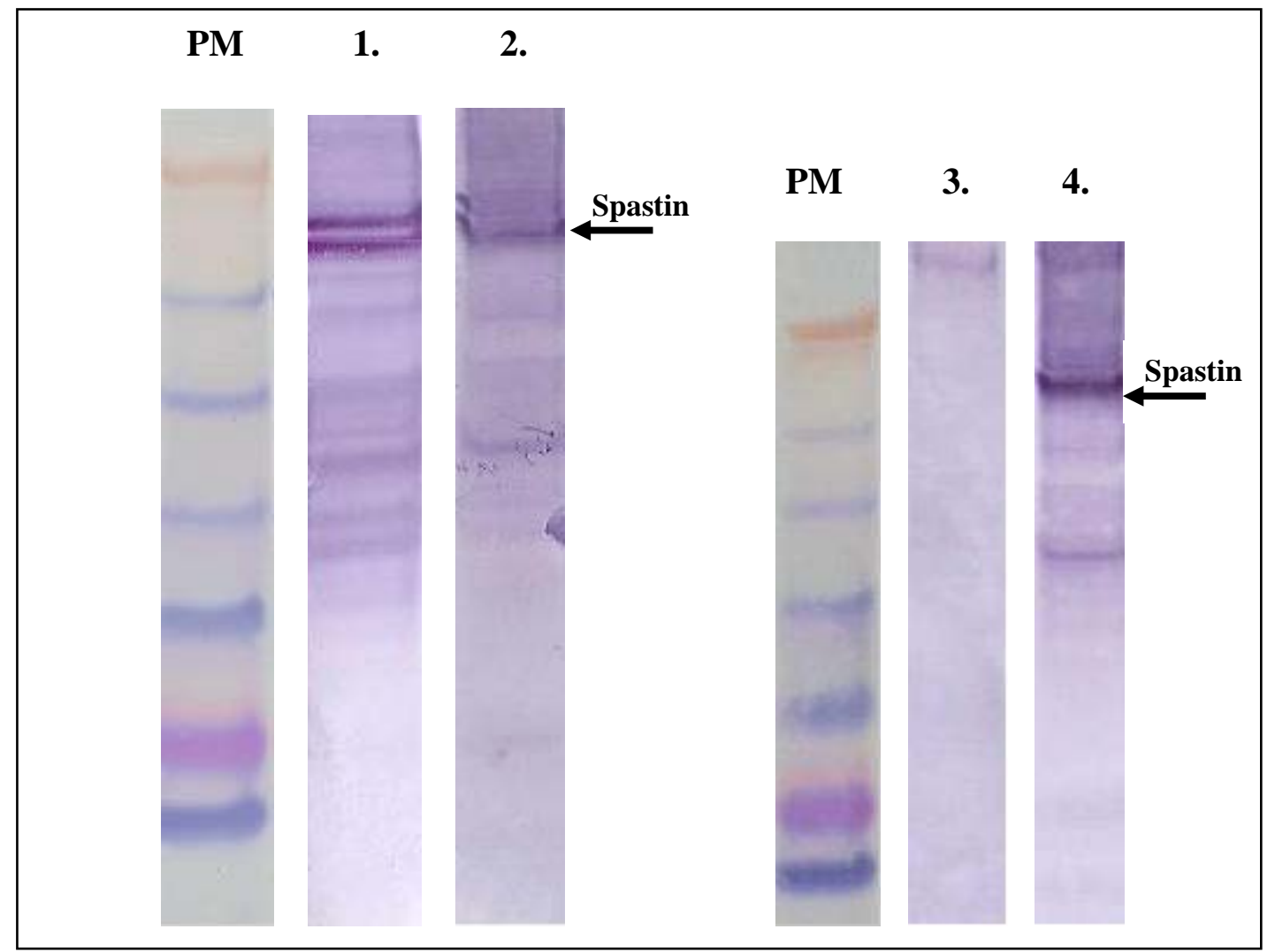

Abb. 3.12: Co-Immunopräzipitation von Cops5 und Spastin nach Isolierung aus NIH3T3-

Zellen. Cops5-E2 wurde mittels spezifischen E2-Antikörper präzipitiert und das interagierende Spastin-c-myc anschließend durch einen spezifischen myc-Antikörper detektiert. PM = Proteinmarker. 1. Positivkontrolle: Anhand des zur Detektion benutzten zweiten Antikörpers gegen die myc-Erkennungsequenz wurde Spastin-c-myc im Zelllysat co-transfizierter Zellen ohne vorherige Präzipitation nachgewiesen. 2. + 4. Interaktion von Cops5 + Spastin: Präzipitation im Zelllysat der co-transfizierten NIH3T3-Zellen durch den ersten Antikörper gegen die E2-Erkennungssequenz des Cops5 und anschließende Detektion von Spastin mittels eines zweiten Antikörpers gegen die mycErkennungssequenz. 3. Negativkontrolle: Keine Detektion von Spastin im Zelllysat nicht transfizierter Zellen.

\subsection{Sequenzierung des COPS5-Gens von Patienten mit klinisch diagnostizierter HSP}

Die HSP bilden eine genetisch heterogene Gruppe neurodegenerativer Erkrankungen. Klinisch lassen sich diese noch in eine reine und in eine komplizierte Form mit zusätzlichen neurologischen Symptomen klassifizieren. Für beide Formen kann die Vererbung autosomal-dominanten, autosomal-rezessiven oder Xchromosomal-rezessiven Erbgängen folgen. Dabei entfallen nahezu 80 \% der Fälle 
auf die autosomal-dominante und etwa $20 \%$ auf die autosomal-rezessive Form. Zu den bis dato 39 bekannten chromosomalen Loci sind erst 16 Genprodukte identifiziert worden. So besteht die Möglichkeit, dass ein Interaktionspartner des Spastins ebenfalls kausal für eine HSP sein kann. Im Rahmen der Charakterisierung von Cops5 durch diese Arbeit (3.2) konnte die Interaktion mit Spastin validiert werden. Auffällig ist, dass der chromosomale Locus von COPS5 in der Nähe des HSP-Locus SPG5 liegt. Für diesen Locus wurde bisher kein Genprodukt identifiziert. Daher wurden mittels Sequenzanalyse die DNA-Proben von 20 Patienten mit einer klinisch diagnostizierten HSP und Ausschluß von Veränderungen in den für SPG3A und SPG4 kodierenden Genen auf Mutationen im Gen für COPS5 untersucht.

\subsubsection{Identifizierung der Exon/Intron-Übergänge und Amplifizierung der Exons von COPS5}

Die Exon/Intron-Übergänge der COPS5-DNA-Sequenz auf genomischer Ebene wurden mithilfe des NCBI-Programms (http://www.ncbi.nlm.nih.gov) ermittelt. COPS5 besteht aus 8 Exons, das Startcodon lokalisiert im ersten Exon, das Stopcodon im letzten Exon. Um auch die Exon/Intron-Übergänge sequenzieren zu können, wurden spezifische, die Exons flankierende Primer generiert. Nach Etablierung eines PCR-Programms an genomischer DNA zur Amplifizierung aller Exons mit ihren Intron-Übergängen unter Verwendung der generierten Primer konnten die 8 Exons sequenziert werden. Dafür kamen die gleichen spezifischen Primer zum Einsatz. Zunächst wurde mit einem Forward-Primer sequenziert und im Falle einer Veränderung auf DNA-Ebene ebenfalls mit einem Reverse-Primer. Das Ergebnis ist jeweils durch eine wiederholte Amplifizierung und Sequenzierung des betreffenden Exons verifiziert worden.

\subsubsection{Veränderungen der COPS5-Sequenz auf DNA-Ebene}

Durch Sequenzierung der Exon-Bereiche einschließlich der angrenzenden intronischen Übergänge von 20 Patienten konnten 3 Veränderungen (Tab 3.1) im 
COPS5-Gen gefunden werden. Die Veränderungen betreffen zum einen die 5’-UTR, zum anderen aber auch den exonischen und intronischen Bereich (Abb. 3.13). Aufgrund der Degeneration des genetischen Codes bedingt die gefundene Veränderung im Bereich des zweiten Exons an der letzten Stelle eines Tripletts jedoch keinen Austausch einer Aminosäure.

\begin{tabular}{|c|c|c|}
\hline Bereich & Veränderung & Aminosäure \\
\hline 5'UTR & 5'UTR-49A $>$ G & A124A \\
\hline Exon 2 & c.371A $>$ G & - \\
\hline Intron 3 & IVS3+75T $>$ C & . \\
\hline
\end{tabular}

Tab. 3.1: Übersicht der Veränderungen im COPS5-Gen bei Patienten mit klinisch diagnostizierter Hereditärer Spastischer Paraplegie.

A

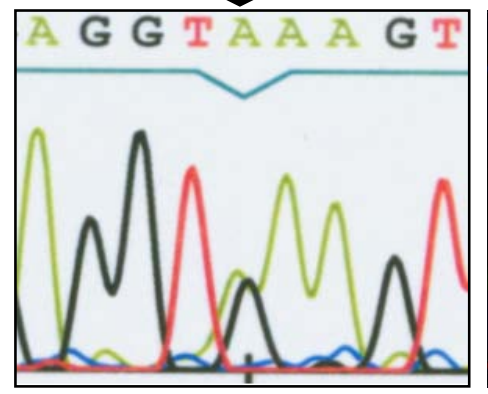

B

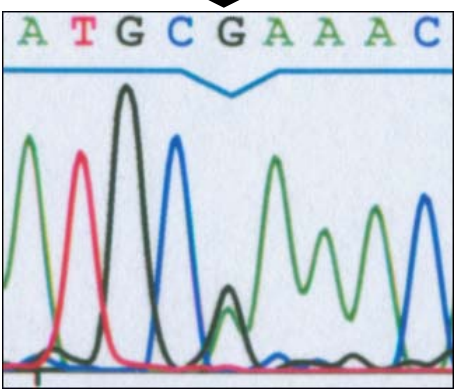

C

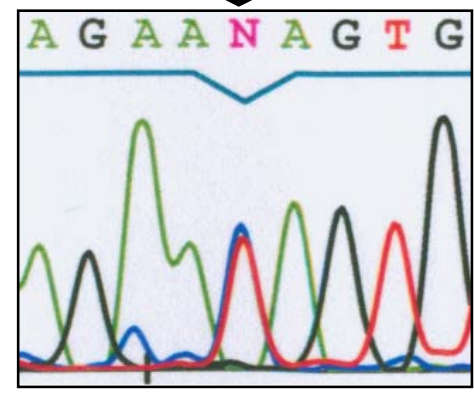

Abb. 3.13: Basenaustausch im COPS5-Gen bei Patienten mit klinisch diagnostizierter HSP. A: Veränderung in der 5'UTR. An Position -49 unterscheiden sich bei 6 Patienten beide DNA-Stränge in einer Base und führen so zu einem übereinander gelagerten Signal. B: Basenaustausch an Pos. 371 im Exon 2. Bei einem Patienten fand sich ein heterozygoter Tausch $A>G$. Da es die letzte Base des Tripletts GCA ist, kodiert das veränderte Triplett GCG ebenfalls für die Aminosäure Alanin. C: Veränderung im intronischen Bereich 3. Ein heterozygoter Basentausch im Intron 3 an Pos. +75 von Thymin zu Cytosin konnte bei 11 Patienten demonstriert werden. 


\section{$4 \quad$ Diskussion}

\subsection{Problemstellung}

Die Hereditären Spastischen Paraplegien als neurodegenerative Erkrankungen bilden eine heterogene Gruppe mit derzeit weit über 30 identifizierten Genloci. Die ursächlichen Gene und Genprodukte sind jedoch nur für 16 Loci bekannt. Mit der Hypothese, dass mittels direkter Wechselwirkung die intrazelluläre Funktion des Spastins durch Interaktionspartner beeinflusst wird und diese Partner damit selbst eine pathophysiologische Relevanz als Kandidaten für eine HSP besitzen, wurde mit einem Yeast-Two-Hybrid-System nach möglichen interagierenden Proteinen gesucht. Vier putative Partner als mögliche Kandidaten konnten mittels dieser Methode identifiziert werden: COPS5, RTN1, RTN3 und FLJ40626 (Böhm, 2003).

Ziel der vorliegenden Arbeit war eine molekulare Charakterisierung des COPS5Gens und seines Genproduktes als Kandidatengen für die Hereditäre Spastische Paraplegie.

In einem ersten Schritt sollte das COPS5-Genprodukt auf subzellulärer Ebene charakterisiert sowie die zuvor in vitro gefundene Interaktion mit Spastin verifiziert werden. Unabhängig von diesen Studien wurden in einem zweiten Schritt Mutationsanalysen in Bezug auf das COPS5-Gen bei HSP-Patienten durchgeführt, bei denen keine Mutation im SPG3A- und SPG4-Gen nachgewiesen werden konnte. 


\subsection{COPS5 als Interaktionspartner des Spastins}

\subsubsection{Struktur, Isoformen und subzelluläre Lokalisation von Spastin}

Spastin wird in die Subgruppe 7 der AAA-ATPasen (ATPases associated with various cellular activities) eingeteilt (Frickey und Lupas, 2004). Die AAAProteinfamilie zeichnet sich durch die Beteiligung an verschiedenen zellulären Prozessen aus. Neben der Genese von Zellorganellen und der Funktion in Proteasomen zählen hierzu auch der Transport an Membranen und die Regulation von Mikrotubuli (Vale, 2000).

Spastin enthält mehrere große Domänen (Abb. 4.1), neben der am C-Terminus lokalisierten AAA-Domäne findet sich N-terminal eine MIT- (microtubuleinteracting and endosomal trafficking) Domäne. Ebenfalls am N-terminalen Ende des Spastins liegt zusätzlich noch eine mögliche Transmembrandomänne (Salinas et al., 2007). Darüber hinaus konnten NLS- (nuclear localization signals) und NES(nuclear export signals) Motive in der Polypeptidkette identifiziert werden (Beetz et al., 2004; Claudiani et al., 2005).

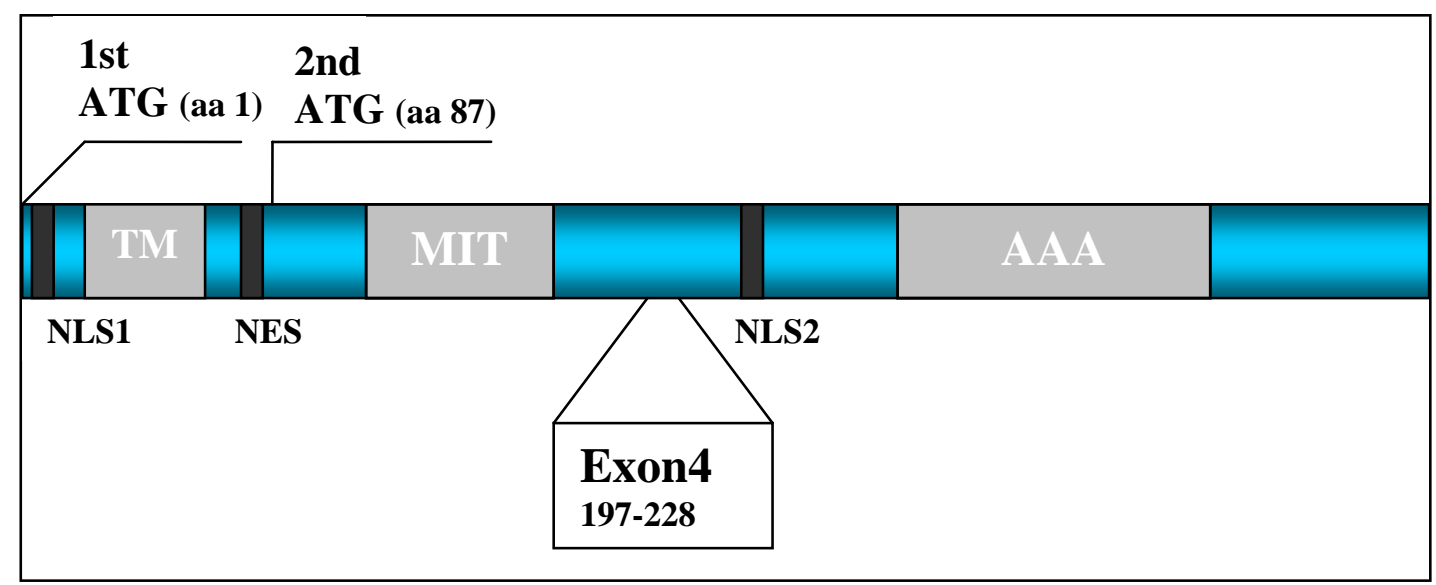

Abb. 4.1: Schematische Darstellung der Spastin-Struktur. Spastin enthält 3 Hauptdomänen sowie drei funktionelle Lokalisationssignale. TM = Transmembrandomäne (aa 57-79). MIT = microtubuleinteracting and endosomal trafficking domain (aa 116-194). AAA = ATPase associated with various cellular acitivities (aa 374-510). NLS = nuclear localization signal: NLS1 (aа 4-11), NLS2 (aа 309312). NES = nuclear export signal (aa 50-87). Adaptiert nach Salinas et al. (2007). 
Zur subzellulären Lokalisation des Spastins gibt es verschiedene, z.T. widersprüchliche Angaben. Erste Studien beschrieben es in neuronalen Zellen als ein nukleäres Protein (Charvin et al., 2003). Über eine zytoplasmatische und/oder eine nukleäre Lokalisation in Abhängigkeit von der neuronalen Zellpopulation wurde jedoch ebenso berichtet (Wharton et al., 2003; Beetz et al., 2004). Dabei ist zu beachten, dass bei den Experimenten verschiedene Isoformen des Spastins eingesetzt wurden (Tab. 4.1). Claudiani et al. publizierten hierzu 2005 eine Studie, die zeigte, dass von der SPG4-mRNA zwei Isoformen translatiert werden können mit etwa 60 bzw. 68 kDa Größe. Im Gegensatz zur längeren Isoform mit Translation beginnend am ersten ATG-Startcodon, lässt die kürzere Isoform ohne die ersten 86 Aminosäuren mit Translationsbeginn am zweiten ATG-Startcodon die postulierte Transmembrandomäne und das NES vermissen. Beide Varianten werden in den Nukleus importiert, aber die das NES enthaltende größere 68-kDA-Isoform wird aktiv wieder exportiert. Während die kürzere Isoform in relevanten Mengen sowohl im Nukleus als auch im Zytoplasma präsent ist, scheint die größere 68-kDA-Isoform wieder aus dem Nukleus transportiert zu werden und lokalisiert zytoplasmatisch. Mit Blick auf die Hereditäre Spastische Paraplegie erscheint weiterhin bemerkenswert, dass die längere, mehrheitlich zytoplasmatische Isoform zwar absolut betrachtet in geringerer Menge translatiert wird, aber im Gehirn und im Rückenmark von Mäusen und damit zweier im Rahmen der HSP histopatholgisch besonders relevanter Gewebe stärker angereichert ist als in anderen Geweben. Innerhalb des Zytoplasmas wiederum ist Spastin im Bereich der Spindelpole und den Mittelkörpern ebenso vermehrt angereichert wie in den distalen Axonen von Motorneuronen (Errico et al., 2004). In Drosophila melanogaster lokalisiert Spastin ebenfalls in den Axonen und Synapsengebieten (Trotta et al., 2004). 


\begin{tabular}{|c|c|}
\hline $\begin{array}{c}\text { Spastin } \\
\text { Isoform }\end{array}$ & $\begin{array}{c}\text { MW } \\
\text { (kDa) }\end{array}$ \\
\hline 1st ATG; +Ex4 & 67.2 \\
\hline 2nd ATG; +Ex4 & 58.0 \\
\hline 1st ATG; $\Delta$ Ex4 & 63.6 \\
\hline 2nd ATG; $\Delta$ Ex4 & 54.4 \\
\hline
\end{tabular}

Tab. 4.1: Übersicht der Spastinisoformen und ihrer Molekulargewichte. Es wurde über verschiedene Isoformen berichtet, abhängig vom Gebrauch des ersten oder zweiten ATG-Startcodons und der An- oder Abwesenheit von Exon 4 (aa 197-228).

Claudiani et al. haben ebenfalls darauf hingewiesen, dass die Regulation des präferierten ATG-Startcodons und damit folglich der translatierten Isoform durch die 5'-untranslatierte Region kontrolliert wird. Ein Fehlen dieser Region in für Spastin kodierenden Plasmiden führt daher zu einer verstärkten Expression der größeren Isoform mit zytoplasmatischem Verteilungsmuster.

Das Verteilungsmuster für Plasmide ohne die 5'UTR bestätigte sich in dieser Arbeit (3.2.5). Single Transfection von Säugetierzellen mit Spastin-Konstrukten, die mittels Antikörper sichtbar gemacht werden konnten, zeigten ein zytoplasmatisches Verteilungsmuster.

\subsubsection{COPS5}

COPS5 (homo sapiens cop9 constitutive morphogenic homolog subunit 5) stellt die fünfte Untereinheit des COP9(CSN)-Signalosom-Komplexes dar und firmiert ebenfalls unter der Bezeichnung CSN5 bzw. JAB1 (Zhang et al., 2007). Der ursprünglich in Arabidopsis (Wei und Deng, 1992) identifizierte CSN-Komplex konnte 1998 von Seeger et al. auch in menschlichen Zellen nachgewiesen werden. Der an diversen zellulären und entwicklungsbiologischen Prozessen partizipierende Komplex setzt sich aus insgesamt 8 Untereinheiten (CSN1 - 8) zusammen, die ausgehend von Arabidopsis über Drosophila bis zum Menschen, durch eine hohe evolutionäre Konservierung imponieren. Den gesamten Komplex betrachtend, zeigt 
hierbei die fünfte Untereinheit (CSN5/COPS5) die größte Übereinstimmung in der Identität der Aminosäuren. Die homologen COPS5-Proteine von Arabidopsis und Mensch weisen dabei in ihrer Aminosäurensequenz eine Übereinstimmung von etwa $60 \%$ auf. Auch mit dem 19S-Proteasomen-lid-Komplex und dem eukaryotischen Initiationsfaktor eIF3 teilt der CSN-Komplex eine hohe strukturelle Ähnlichkeit. Hauptsächlich bedingt wird sie durch die vorherrschenden Domänen seiner Untereinheiten, PCI (proteasome, COP9 signalosome, initiation factor 3) und MPN (Mpr1-Pad1-N-terminal) (Wei und Deng, 2003). Das COPS5-Protein wurde ursprünglich im Rahmen seiner Interaktion mit Transkriptionsfaktoren identifiziert (Claret et al., 1996). Strukturell findet sich an seinem N-terminalen Ende ein als MPN-Domäne bekannter Abschnitt (Hofmann und Bucher, 1998). Eingebettet in diese ist ein Metalloprotease-Motiv, das als JAMM-Motiv bezeichnet wird (Cope et al., 2002). Es bildet ein katalytisches Zentrum zur Entfernung von Ubiquitin oder Ubiquitin-ähnlichen Proteinen von Bestandteilen des Ubiquitin-ProteasomenSystems (Burger-Kentischer et al., 2005). Darüber hinaus findet sich zwischen den Aminosäuren 233 und 242 ein speziesübergreifend konserviertes Leucin-reiches nukleäres Exportsignal (NES) (Abbildung 4.2) (Tomada et al., 2002).

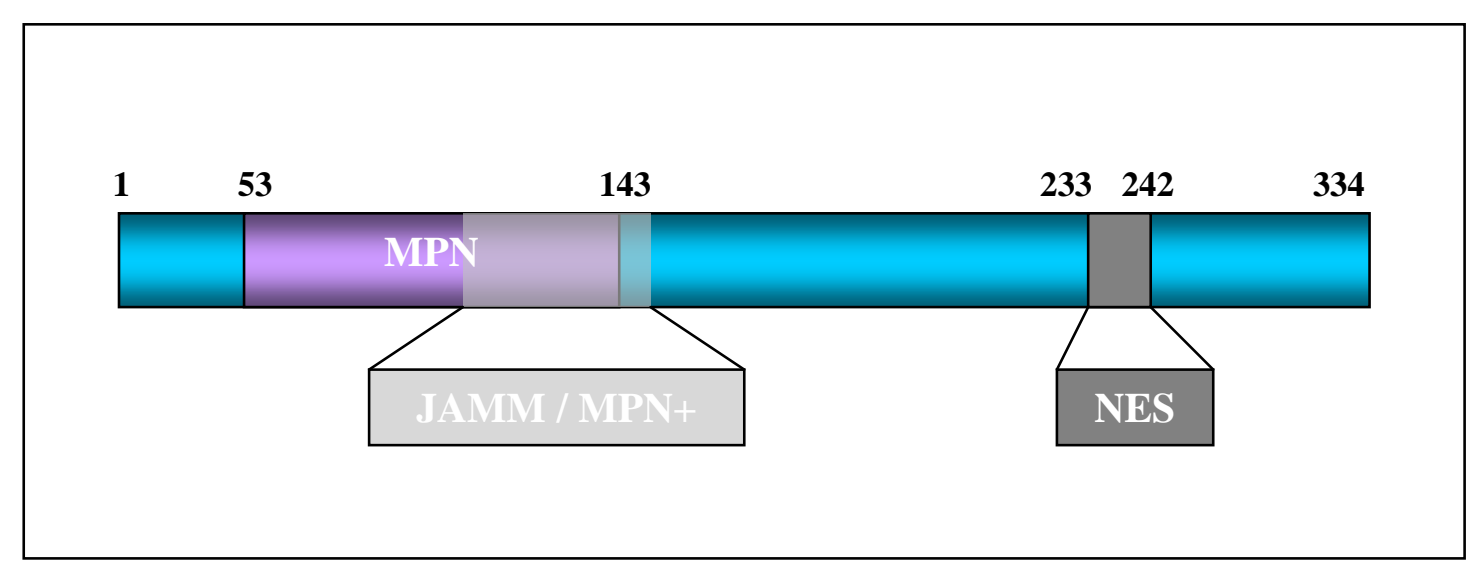

Abb. 4.2: Schematische Darstellung der COPS5-Struktur. COPS5 enthält eine als MPN bezeichnete Domäne mit einem hierin eingebetteten Metalloprotease-Motiv und ein nukleäres Exportsignal. MPN = Mpr1-Pad1-N-terminal (aa 53-143). JAMM = Jab1/MPN domain metalloenzyme. NES = nuclear export signal (aa 233-242). 
Neben der Integration in den CSN-Gesamtkomplex findet sich COPS5 in der Zelle jedoch auch in einer zweiten, nicht in den Gesamtkomplex integrierten Form mit zumeist geringerer molekularer Masse. Von einer monomerischen Form in Arabidopsis (Kwok et al., 1998) und Säugetierzellen (Yang et al., 2002) bis zu einer etwa 200 kDa großen Form in Schizosaccharomyces pombe (Mundt et al., 2002).

\subsubsection{Subzelluläre Lokalisation von Cops5}

Während der CSN-Holokomplex mehrheitlich nukleär lokalisiert gefunden wird (Staub et al., 1998; Schaefer et al., 1999), wird für COPS5 in seiner freien Form sowohl eine nukleäre als auch eine zytoplasmastische Verteilung berichtet (Bounpheng et al., 2000). Mini CSN-Komplexe, mit COPS5 und nur wenigen anderen CSN-Untereinheiten, zeigen hingegen ein überwiegend zytosolisches Verteilungsmuster. Es verdichtet sich aber das Bild, dass die Verteilung von COPS5 komplex reguliert wird. Wie erwähnt besitzt COPS5 ein nukleäres Transportsignal. Bei Punktmutationen in diesem Signal konnte gezeigt werden, dass die Fähigkeit von COPS5 zum nukleären Transfer und der anschließende Abbau des Inhibtors der Cyclin-abhängigen Kinase p27 reduziert ist (Tomoda et al., 2002). Tomoda et al. weisen ebenfalls daraufhin, dass die ektopische Überexpression von COPS5 mit Erkennungssequenzen für Antikörper in kultivierten Zellen zu einer verminderten Inkorporation in den CSN-Gesamtkomplex führt. Eine große Fraktion von überexprimiertem COPS5 findet sich in freier Form.

Vor Untersuchung der subzellulären Darstellung in dieser Arbeit wurde die Lokalisation von COPS5 anhand einer Expression in embryonalen und adulten Säugetierzellen analysiert. Besonderes Augenmerk galt dabei dem Expressionsnachweis in neuronalen Geweben (3.1). Nach einer RT-PCR an isolierter RNA der Zellen konnten die erwarteten Amplifikate in einer gelelektrophoretischen Auftrennung demonstriert werden. Nach Demonstration der zellulären Expression folgte die Transfektion von Säugetierzellen (NIH3T3) mit Cops5-Konstrukten, die eine Erkennungssequenz an ihrem N-terminalen Ende trugen. Für diese Konstrukte konnte fluoreszenzmikroskopisch ein vesikulär zytoplasmatisches Verteilungsmuster gezeigt werden (3.2.4). 


\subsubsection{Cops5 interagiert mit Spastin}

Das COPS5-Genprodukt konnte in einem Y2H-System von unserer Gruppe als ein putativer Interaktionspartner des Spastins identifiziert werden. Dabei ist aber zu beachten, dass diese Methode zum einen nicht spezifisch ist und zum anderen für Saccharomyces cerevisiae andere Proteine das Ergebnis beinflussen können. Diese Proteine können möglicherweise eine Interaktion in Hefezellen bewirken, während sie in mehrzelligen eukaryotischen Organismen nicht vorkommen.

In dieser Studie konnte die Interaktion beider Proteine erstmals mittels CoImmunopräzipitation bestätigt werden (3.2.6.2). Da die Generierung von humanen COPS5-Konstrukten mit Erkennungssequenz für Antikörper nicht gelang, wurde die homologe Mausvariante eingesetzt. Humanes COPS5-Protein und murines Cops5Protein zeigen jedoch eine Sequenzübereinstimmung auf Peptidebene von nahezu 100 \% (siehe Anhang). Die mit antikörperspezifischen Epitopen fusionierten Proteine Cops5 und Spastin wurden durch an Antikörper gekoppelte magnetische Partikel aus einem eukaryotischen Zelllysat (NIH3T3) co-immunopräzipitiert und Cops5 durch Western-Blot-Analyse anschließend detektiert. Somit konnte neben dem Y2H-System mit einer weiteren Methode gezeigt werden, dass Spastin in Säugetierzellen spezifisch mit Cops5 interagiert. Unterstützt wird dieses Ergebnis durch immunfluoreszenzmikroskopische Untersuchungen der subzellulären CoLokalisation beider Proteine in NIH3T3-Zellen. Es konnte hier die zytoplasmatische Co-Lokalisation von COPS5 bzw. Cops5 und Spastin belegt werde (3.2.6.1).

\subsubsection{Physiologische Relevanz der COPS5 - Spastin Interaktion}

Das für Spastin kodierende SPG4-Gen stellt das am häufigsten mutierte HSP-Gen dar und ist für ungefähr etwa 40 \% der autosomal-dominanten Fälle verantwortlich (Hazan et al., 1999). Dabei konnte eine Vielzahl von Mutationen identifiziert werden, Missense-, Nonsense- und Spleißsitemutationen, Deletionen und Insertionen (Fonknechten et al., 2000). Die meisten dieser Mutationen fallen in die oben beschriebene AAA-Domäne des SPG4 (Lindsey et al., 2000). Die Sequenzanalyse von Spastin ergab Homologien mit Katanin, ebenfalls ein AAAProtein. Katanin ist beteiligt am Zerlegen von Mikrotubuli (MT), es vermag mittels 
einer Untereinheit MT zu binden, zu oligomerisieren und ATP-abhängig zu zerschneiden. Eine zweite Untereinheit heftet diesen Katanin-Komplex an das Zentrosom (Baas et al., 2005). Zusammen mit der Beobachtung, dass Spastin die MT-Dissoziation in Zellen unterstützt, ließ dies an eine Beteiligung von Spastin in der Regulation des MT-Umsatzes denken (Errico et al., 2002). MT sind für Zelltransport und Zellteilung sowie andere Funktionen essentielle Polymere. Länge und Erscheinungsform hängen dabei von assoziierten Proteinen (MAP) sowie stabilisierenden und destabilisierenden Faktoren ab, mit dem Ergebnis eines präzisen räumlichen und zeitlichen Verteilungsmusters (Nogales, 2000). Das Zerlegen von MT ist an die ATPase-Aktivität des Spastins gekoppelt, da ATPasedefiziente Spastinformen diese Fähigkeit nicht zeigen (Evans et al., 2005; RollMecak und Vale 2005). Neben dieser Funktion konnte für Spastin und einige Formen mit Mutationen in der AAA-Domäne aber auch gezeigt werden, dass Spastin in der Lage ist, MT zu bündeln (Salinas et al., 2007). Mittels dem sogenannten NA14, einem Protein im Zentrosom von Säugetierzellen, wird die Interaktion zwischen Spastin und MT vermittelt. Deletionen in der NA14-bindenden Region des Spastins bewirken eine Behinderung der Interaktion mit MT, was zusammen mit dem Anreicherungsmuster des Spastins an den Spindelpolen, dem Zentrosom und den distalen Axonen, auf die Bedeutung des Spastins für die Dynamik und das Rearrangement des Zytoskeletts hinweist (Errico et al., 2004). Die Homöostase des axonalen Transports ist von großer Bedeutung in Bezug auf die Entstehung von Krankheiten und ruht auf einem funktionierendem MT-Netzwerk (Holzbaur, 2004). Ein gestörter mitochondrialer Transport konnte für Zellen mit Überexpression mutierten Spastins gezeigt und in postmortalen Rückenmarksschnitten von SPG4-Patienten gefunden werden (McDermott et al., 2003). Das histopathologische Korrelat der spastischen Paraplegien ist die distale Degeneration der langen Motorneurone des Rückenmarks. Diese sind aufgrund ihrer Länge und hohen Polarität in besonderer Weise von komplizierten und exakt wirkenden Transportmechanismen abhängig (Almenar-Queralt und Goldstein, 2001). Entsprechend kann den Mikrotubuli als einer Art Rückgrat der intrazellulären Transportmechanismen eine besondere Bedeutung zukommen.

Vom CSN-Komplex ist eine intrinsische Metalloproteaseaktivität bekannt, die innerhalb des COPS5-Proteins lokalisiert ist (Cope et al., 2002). Diese enzymatische 
Aktivität vermag das Ubiquitin-ähnliche Protein NEDD8 von Cullinen zu entfernen, ein Prozess der als „Deneddylation“ bezeichnet wird (Schwechheimer et al., 2001; Lyapina et al., 2001). Culline wiederum dienen als eine Art Baugerüst für Ubiquitinligasen (Willems et al., 2004; Petroski und Deshaies, 2005). Zyklen von Neddylation und CSN-vermittelter Deneddylation regulieren dann diese Ligasen (Wee et al., 2005). Neben dieser Eigenschaft ist der CSN-Komplex mit Kinasen assoziiert (Uhle et al., 2003). Diese vermögen Substrate des Ubiquitin-ProteasomenSystems zu modifiziieren und beeinflussen so ihre Stabilität (Bech-Otschir et al., 2005). Schließlich ist der CSN-Komplex noch mit dem Deubiquinase Enzym USP 15 assoziiert (Hetfeld et al., 2005). Die Protease reguliert Ubiquitinligasen sowie andere Adaptorproteine des Komplexes und schützt sie so vor Autoubiquination und anschließender Degradation (Wee et al., 2005). Tatsächlich interagiert COPS5 selbst mit unzähligen Proteinen, die oft das Zielobjekt für den CSN-Komplex darstellen. In einigen Fällen wie p53, p27, rLHR precursor und Smad4 stimuliert die COPS5Bindung so den nachfolgenden Proteinabbau, während in anderen Fällen wie HIF1$\alpha$ und c-Jun die Bindung einen stabilisierenden Effekt hat (Wei und Deng, 2003).

Auch eine funktionelle Beziehung zwischen dem CSN-UPS-Weg und dem Mikrotubulinetzwerk konnte durch Peth et al. 2007 hergestellt werden. Das Mikrotubulibindungsprotein EB1 interagiert mit dem CSN-Komplex. Die Bindung des Komplexes an das EB1 Protein wird über COPS5 vermittelt. Folge der Interaktion und einer folgenden damit assoziierten Phosphorylierung ist eine Stabilisierung des EB1 gegenüber einer Degradation durch das UbiquitinProteasomen-System. Wie oben bereits erwähnt, kommt einem funktionierenden Mikrotubulinetzwerk eine zentrale Rolle im intrazellulärem Vesikeltransport, dem Aufrechterhalten der Zellform oder der Chromosomensegregation zu. EB1 wiederum kommt eine wichtige Rolle im dynamischen Auf- und Abbau des MTNetzwerkes zu, es bindet an die Enden von MT und fördert deren Polymerisation. In ihrer Studie konnnten Peth et al. so zeigen, dass der CSN-Komplex und dem damit verbunden UPS eine wesentliche Regulatorfunktion in der Dynamik und Funktion des Zytoskeletts zukommt. Ein zukünftiges Experiment sollte daher die COPS5 Spastin Interaktion im Hinblick auf eine mögliche Kooperation beider Proteine / Proteinkomplexe in der Regulation der MT-Dynamik und damit einem 
wahrscheinlichen Schlüsselelement in der Pathophysiologie der Hereditären Spastischen Paraplegien untersuchen.

\subsection{DNA-Analyse von Patienten mit klinisch diagnostizierter HSP}

Hereditäre Spastische Paraplegien (HSP) zeigen sowohl eine klinische als auch eine genetische Heterogenität. Ihr charakteristisches klinisches Merkmal ist die fortschreitende Spastizität der unteren Extremitäten. Genetisch folgen die einzelnen Formen autosomal-dominanten, autosomal-rezessiven oder X-chromosomalen Vererbungsmustern. Bis heute konnten 39 Loci (SPG) kartiert und dazu 16 verantwortliche Gene identifiziert werden. Die chromosomale Lokalisation 8q12.3 von COPS5 stimmte zu Beginn dieser Arbeit mit dem SPG5-Locus überein, eine autosomal-rezessive Form der HSP (ARHSP). Während über $40 \%$ der autosomaldominanten Fälle an die beiden Hauptloci SPG3A und SPG4 gekoppelt sind, ist weniger über die autosomal-rezessiven Formen der HSP bekannt, da die kartierten Loci nur in wenigen Familien, oft nur in einer identifiziert wurden, und nur für einen geringen Prozentsatz der gesamten HSP-Fälle verantwortlich sind (Klebe et al. 2007). COPS5-Mutationen im Hinblick auf SPG5 sollten entsprechend möglich sein, wenn auch nicht von einem hochfrequenten Auftreten auszugehen war.

Wie die Gesamtheit der HSP so bilden auch die ARHSP in sich eine genetisch und klinisch sehr heterogene Gruppe. Viele der Entitäten wurden oft nur in einer Familie gefunden. Bisher wurden 17 Loci beschrieben (Tabelle 4.2), es konnten mit Paraplegin (SPG7), Spatacsin (SPG11), Spastizin (SPG15), Spartin (SPG20) und Maspardin (SPG21) aber erst fünf Gene identifiziert werden. Der SPG5-Locus wurde zuerst als eine $32.8 \mathrm{cM}$ große Region auf Chromosom 8 beschrieben (Hentati et al., 1994), in der Folge bestätigt sowie weiter eingegrenzt (Coutinho et al., 1999). Klinische und genetische Untersuchungen an einer konsanguinen Familie konnten den Locus zwischen den polymorphen Markern D8S1833 und D8S285 erfassen, ein 23 cM großes Referenzintervall (Wilkinson et al., 2003). Innerhalb dieses Intervalls auf Chromosom 8 lokalisiert mit 8q12.3 auch COPS5. Entsprechend konnte COPS5 und sein Genprodukt als bestätigter Interaktionspartner des Spastins als Kandidat für die Ursache einer HSP gelten. 


\begin{tabular}{|c|c|c|c|c|}
\hline & Genlocus & Genprodukt & Vererbung & HSP-Form \\
\hline SPG5 & $8 q 12-q 13$ & unbekannt & autosomal-rezessiv & rein \\
\hline SPG7 & $16 q 24.3$ & Paraplegin & autosomal-rezessiv & kompliziert \\
\hline SPG11 & 2q33.1 & Spatacsin & autosomal-rezessiv & rein \\
\hline SPG14 & $3 q 27-q 28$ & unbekannt & autosomal-rezessiv & kompliziert \\
\hline SPG15 & $14 q 22-q 24$ & Spastizin & autosomal-rezessiv & kompliziert \\
\hline SPG20 & $13 q 12.3$ & Spartin & autosomal-rezessiv & kompliziert \\
\hline$S P G 21$ & $15 q 22.31$ & Maspardin & autosomal-rezessiv & rein \\
\hline SPG23 & $1 \mathrm{q} 24-\mathrm{q} 32$ & unbekannt & autosomal-rezessiv & kompliziert \\
\hline SPG24 & $13 q 14$ & unbekannt & autosomal-rezessiv & rein \\
\hline SPG25 & $6 q 23.3-q 24.1$ & unbekannt & autosomal-rezessiv & rein \\
\hline SPG26 & $\begin{array}{l}12 \mathrm{p} 11.1- \\
12 \mathrm{q} 14\end{array}$ & unbekannt & autosomal-rezessiv & kompliziert \\
\hline SPG27 & $10 q 22.1-q 24.1$ & unbekannt & autosomal-rezessiv & rein \\
\hline SPG28 & $14 q 21.3-q 22.3$ & unbekannt & autosomal-rezessiv & rein \\
\hline SPG30 & $2 q 37.3$ & unbekannt & autosomal-rezessiv & kompliziert \\
\hline SPG32 & $14 q 12-q 21$ & unbekannt & autosomal-rezessiv & rein \\
\hline SPG35 & $16 q 21-q 23.1$ & unbekannt & autosomal-rezessiv & kompliziert \\
\hline SPG39 & $19 p 13$ & unbekannt & autosomal-rezessiv & kompliziert \\
\hline
\end{tabular}

Tab. 4.2: Übersicht der autosomal-rezessiven Genloci und der entsprechenden Genprodukte im Zusammenhang mit der Spastischen Paraplegie. SPG = Spastische Paraplegie.

Es wurden daher die aus Leukozyten gewonnen DNA-Proben von insgesamt 20 Patienten mit Ausschluß von Veränderungen im SPG3A- und SPG4-Gen in Bezug auf Mutationen im COPS5-Gen analysiert. Es konnte ein Basenaustausch im codierenden Bereich des COPS5-Gens gefunden werden. Im Exon 2 wurde die Veränderung c.371A $>\mathrm{G}$ bei einem Patienten detektiert. Da der genetische Code degeneriert ist, hat dieser Basenaustausch an der dritten Position des Tripletts keine 
Auswirkung auf die dem Codon entsprechende Aminosäure (3.3). Sowohl das Basentriplett GCA, als auch das Triplett GCG kodiert für die Aminosäure Alanin. Eine weitere Veränderung, die bei sechs Patienten gefunden werden konnte, betraf die 5'-untranslatierte Region. Dort fand der heterozygote Basenaustausch -49A>G statt. Die dritte gefundene Veränderung betraf die intronische Sequenz (IVS3+75T $>$ C) und konnte bei 11 Patienten des Untersuchungskollektivs demonstriert werden. Grundsätzlich können Veränderungen in untranslatierten und intronischen Bereichen Regulationssequenzen der Genexpression oder für die Prozessierung der RNA essentielle Sequenz betreffen, wozu eine genauere Analyse der identifizierten Veränderungen vorgenommen werden müsste. Damit können Mutationen in solchen Bereichen auch die Ursache für Erkrankungen sein. Aufgrund der Häufigkeit mit der die beiden letztgenannten Veränderungen detektiert wurden, dürfte es sich aber vermutlich um Polymorphismen handeln. Zur Bestätigung dieser Interpretation müsste eine statistisch signifikante Anzahl von Kontrollpersonen Antwort liefern. Nach Abschluß der Sequenzierungsarbeiten gelang es, den SPG5-Locus zwar weiter einzugrenzen, auf ein zuerst 11 cM (Muglia et al., 2004) und schließlich 3.8 cM großes Intervall (Klebe et al., 2007), in welches COPS5 nicht mehr direkt lokalisiert. Mutationen in COPS5 könnten jedoch auch einen gänzlich neuen Locus im Rahmen der genetisch heterogenen HSP dastellen. Wie Tab 4.2 zu entnehmen ist, liegen auch die autosomal-rezessiven Spastischen Paraplegien 15, 28 und 32 chromosomal eng beieinander. Hierbei wäre dann auch eine autosomal-dominante Variante zu berücksichtigen, da die in dieser Arbeit untersuchten 20 Patienten mit einer klinisch diagnostizierten HSP nur durch Ausschluss von Veränderungen in den für SPG3A und SPG4 kodierenden Genen selektiert wurden. 


\section{$5 \quad$ Zusammenfassung}

Die Hereditären Spastischen Paraplegien (HSP) bilden eine klinisch und genetisch heterogene Gruppe neurodegenerativer Erkrankungen. Gekennzeichnet sind diese insbesondere durch eine progrediente spastische Tonuserhöhung und Hyperreflexie der unteren Extremitäten. Das Vererbungsmuster der HSP folgt autosomaldominanten, autosomal-rezessiven und X-chromosomalen Erbgängen. Bis dato konnten zwar 39 Loci identifiziert werden, doch die ursächlichen Gene sind in über der Hälfte der Fälle noch unbekannt. Eine besondere Bedeutung kommt dem SPG4Gen zu. Veränderungen in diesem sind für ungefähr $40 \%$ der autosomaldominanten HSP verantwortlich. In einem Y2H konnte gezeigt werden, dass sein Genprodukt Spastin mit COPS5 interagiert. Ziel dieser Arbeit war deshalb eine molekulare Charakterisierung des COPS5-Gens und seines Genproduktes als mögliches Kandidatengen für die HSP.

Zuerst wurde die Transkription von Cosp5 in Wildtyp-Mäusen untersucht. Das Transkript wurde sowohl in Geweben adulter als auch in Geweben embryonaler Mäuse nachgewiesen. Das Cops5-Transkript konnte ebenfalls in allen untersuchten neuronalen Geweben detektiert werden.

Mittels Immunfluoreszenz wurde eine zytoplasmatische Co-Lokalisation von Cops5 und Spastin in Säugetierzellen demonstriert. Die anschließende CoImmunopräzipitation konnte die Interaktion beider Genprodukte bestätigen. Somit konnte mit verschiedenen Methoden gezeigt werden, dass Spastin mit Cops5 spezifisch interagiert.

Die chromosomale Lokalisation von COPS5 stimmte zu Beginn der Arbeit mit dem ARHSP-Locus SPG5 überein und war damit Kandidat für dieses noch nicht identifizierte Gen. Entsprechend wurden bei insgesamt 20 Patienten mit einer klinisch diagnostizierten HSP sowie Ausschluss von Veränderungen in den für SPG3A und SPG4 kodierenden Genen Analysen in Bezug auf eventuelle Mutationen in COPS5 vorgenommen. Es konnten drei Veränderungen - alle vermutlich Polymorphismen - in intronischen und exonischen Bereichen dedektiert werden. 


\section{$6 \quad$ Anhang}

\subsection{Spastin (Homo sapiens) - Kodierende Sequenz für die Isoform II}

atgaattctc cgggtggacg agggaagaag aaaggctccg gcggcgccag caaccoggtg $\Delta$ Exon1

61 cctccoagge ctccgeccec ttgcetggec cccgeccetc cogecgecgg gecggccect ccgccogagt cgccgcataa gcggaacctg tactatttct cctaccogct gtttgtaggc ttcgcgctgc tgcgtttggt cgccttccac ctggggctcc tcttcgtgtg gctctgccag cgcttctccc gcgecctcat ggcagccaag aggagctccg gggccgcgcc agcacctgcc tcggcctcgg cccoggcgec ggtgccgggc ggcgaggccg agcgcgtccg agtcttccac aaacaggcct tcgagtacat ctccattgcc ctgcgcatcg atgaggatga gaaagcagga

481 gctgttatag ttacaggaca aggtgaacag tgtgaaagag ctagacgcct tcaagctaaa atgatgacta atttggttat ggccaaggac cgcttacaac ttctagaaag tggagctgtt \ Exon5 ccaaaaagaa aagacccctt aacacacact agtaattcac tgcctcgttc aaaaacagtt atgaaaactg gatctgcagg cctttcaggc caccatagag cacctagtta cagtggttta tccatggttt ctggagtgaa acagggatct ggtcctgctc ctaccactca taagggtact ccgaaaacaa ataggacaaa taaaccttct acccctacaa ctgctactcg taagaaaaaa gacttgaaga attttaggaa tgtggacagc aaccttgcta accttataat gaatgaaatt gtggacaatg gaacagctgt taaatttgat gatatagctg gtcaagactt ggcaaaacaa $\Delta$ Exon7

961 gcattgcaag aaattgttat tcttccttct ctgaggcctg agttgttcac agggcttaga 1021 gctcctgcca gagggctgtt actctttggt ccacctggga atgggaagac aatgctggct

Exon9 aaagcagtag ctgcagaatc gaatgcaacc ttctttaata taagtgctgc aagtttaact tcaaaatacg tgggagaagg agagaaattg gtgagggctc tttttgctgt ggctcgagaa $\Delta$ Exon10 cttcaacctt ctataatttt tatagatgaa gttgatagcc ttttgtgtga aagaagagaa A Exon11

1261 ggggagcacg atgctagtag acgcctaaaa actgaatttc taatagaatt tgatggtgta 1321 cagtctgctg gagatgacag agtacttgta atgggtgcaa ctaataggcc acaagagctt 
1501 gaactagcac aacttgctag aatgactgat ggatactcag gaagtgacct aacagctttg $\Delta$ Exon15

1561 gcaaaagatg cagcactggg tcctatccga gaactaaaac cagaacaggt gaagaatatg

1621 tctgccagtg agatgagaaa tattcgatta tctgacttca ctgaatcctt gaaaaaata $\Delta$ Exon17

1681 aaacgcagcg tcagccctca aactttagaa gcgtacatac gttggaacaa ggactttgga

1741 gataccactg tttaa 


\subsection{Spastin (Homo sapiens) - Aminosäuresequenz für die Isoform II}

$1 \quad$ mnspggrgkk kgsggasnpv pprppppcla pappaagpap ppesphkrnl yyfsyplfvg

61 fallrlvafh lgllfvwlcq rfsralmaak rssgaapapa sasapapvpg geaervrvfh

121 kqafeyisia lridedekag qkeqavewyk kgieelekgi avivtgqgeq cerarrlqak

181 mmtnlvmakd rlqllesgav pkrkdpltht snslprsktv mktgsaglsg hhrapsysgl

241 smvsgvkqgs gpaptthkgt pktnrtnkps tpttatrkkk dlknfrnvds nlanlimnei

301 vdngtavkfd diagqdlakq alqeivilps lrpelftglr aparglllfg ppgngktmla

361 kavaaesnat ffnisaaslt skyvgegekl vralfavare lqpsiifide vdsllcerre

421 gehdasrrlk tefliefdgv qsagddrvlv mgatnrpqel deavlrrfik rvyvslpnee

481 trllllknll ckqgspltqk elaqlarmtd gysgsdltal akdaalgpir elkpeqvknm

541 sasemrnirl sdfteslkki krsvspqtle ayirwnkdfg dttv 


\subsection{COPS5 (Homo sapiens) - Kodierende Sequenz}

1 atggcggcgt ccgggagcgg tatggcccag aaaacctggg aactggccaa caacatgcag $\Delta$ Exon1

61 gaagctcaga gtatcgatga aatctacaaa tacgacaaga aacagcagca agaaatcctg

121 gcggcgaagc cctggactaa ggatcaccat tactttaagt actgcaaaat ctcagcattg

181 gctctgctga agatggtgat gcatgccaga tcgggaggca acttggaagt gatgggtctg

241 atgctaggaa aggtggatgg tgaaaccatg atcattatgg acagttttgc tttgcctgtg

301 gagggcactg aaaccogagt aatgctcag gctgctgcat atgaatacat ggctgcatac

361 atagaaaatg caaaacaggt tggccgcctt gaaaatgcaa tcgggtggta tcatagccac $\Delta$ Exon3

421 cctggctatg gctgctggct ttctgggatt gatgttagta ctcagatgct caatcagcag

481 ttccaggaac catttgtagc agtggtgatt gatccaacaa gaacaatatc cgcagggaaa

541 gtgaatcttg gcgcctttag gacataccca aagggctaca aacctcctga tgaaggacct

601 tctgagtacc agactattcc acttaataaa atagaagatt ttggtgtaca ctgcaaacaa

$661 \quad$ Exon6 $\boldsymbol{\Delta}$

721 ttgtggaata aatactgggt gaatacgttg agttcttcta gcttgcttac taatgcagac

$\Delta$ Exon7

781 tataccactg gtcaggtctt tgatttgtct gaaaagttag agcagtcaga agcccagctg

841 ggacgaggga gttcatgtt gggtttagaa acgcatgacc gaaaatcaga agacaaactt

901 gccaaagcta caagagacag ctgtaaact accatagaag ctatccatgg attgatgtct

$\begin{aligned} & \mathbf{\Delta} \text { Exon8 } \\ & 961 \quad \text { caggttatta aggataact gtttaatcaa attaacatct cttaa }\end{aligned}$ 


\subsection{Cops5 (Mus musculus) - Kodierende Sequenz}

1 atggcagctt ccgggagtgg tatggcccag aaaacctggg aattggccaa caacatgcag

\section{$\Delta$ Exon1}

61 gaagcgcaga gtatcgatga aatctacaaa tatgacaaaa aacaacaaca agaaatcctg

121 gcggcgaaac cctggactaa ggatcaccac tactttaaat actgcaaaat ctcagcattg

\section{$\Delta$ Exon2}

181 gctctactga aaatggtgat gcatgccagg tcaggaggca acttggaagt gatgggtttg

241 atgctcggga aagtcgacgg cgagaccatg atcatcatgg acagtttcgc tttgcctgta

301 gagggcacag aaactcgagt aatgctcaa gctgctgcgt atgagtatat ggctgcatac

361 atagaaaatg ccaaacaggt tggccgcctt gagaatgcaa tcggttggta tcatagccac $\Delta$ Exon3

421 cctggttatg gctgctggct ctccgggatt gatgttagta cacagatgct gaaccagcag

481 tttcaagaac catttgtagc agtggtgatt gatccaacca gaacaatctc tgcaggaaaa

541 gtgaatcttg gcgcctttag gacatatcca aagggctaca aacctcctga tgaaggacct

$601 \quad$ tctgagtacc agactatccc acttaataaa atagaagatt ttggcgtgca ctgcaaacaa

661 tattatgcet tagaagtctc atatttcaaa tcatctttgg atcotaact acttgagctt

721 ttgtggaata aatactgggt gaataccctg agttcctcta gcttgcttac taatgcagac

$\Delta \boldsymbol{\Delta}$ Exon7

781 tacaccacag gccaggtgtt tgatttgtct gagaagttag agcagtcgga agcccaactg

841 ggacgtggca gttcatgtt gggcttagaa acacatgacc gcaagtcgga agacaaactt

901 gccaaagcta ctagagacag ctgtaaacc accatagaag ccatccatgg actgatgtct

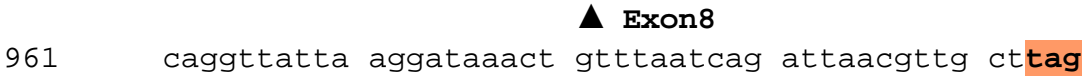




\subsection{COPS5 (Homo sapiens) - Aminosäuresequenz}

1

61

\subsection{Cops5 (Mus musculus) - Aminosäuresequenz}

1

maasgsgmaq ktwelannmq eaqsideiyk ydkkqqqeil aakpwtkdhh yfkyckisal

61

121

181

241 maasgsgmaq ktwelannmq eaqsideiyk ydkkqqqeil aakpwtkdhh yfkyckisal allkmvmhar sggnlevmgl mlgkvdgetm iimdsfalpv egtetrvnaq aaayeymaay ienakqvgrl enaigwyhsh pgygcwlsgi dvstqmlnqq fqepfvavvi dptrtisagk vnlgafrtyp kgykppdegp seyqtiplnk iedfgvhckq yyalevsyfk ssldrkllel lwnkywvntl sssslltnad yttgqvfdls ekleqseaql grgsfmlgle thdrksedkl akatrdsckt tieaihglms qvikdklfnq inis ienakqvgrl enaigwyhsh pgygcwlsgi dvstqmlnqq fqepfvavvi dptrtisagk vnlgafrtyp kgykppdegp seyqtiplnk iedfgvhckq yyalevsyfk ssldrkllel lwnkywvntl sssslltnad yttgqvfdls ekleqseaql grgsfmlgle thdrksedkl akatrdsckt tieaihglms qvikdklfnq inva 


\subsection{Aminosäuren-Alignement}

Sequenz 1: COPS5 (Homo sapiens)

Sequenz 2: Cops5 (Mus musculus)

Identities $=332 / 334(99 \%)$, Positives $=334 / 334(100 \%)$, Gaps $=0 / 334(0 \%)$

Query 1 MAASGSGMAQKTWELANNMQEAQSIDEIYKYDKKQQQEILAAKPWTKDHHYFKYCKISAL 60

MAASGSGMAQKTWELANNMQEAQSIDEIYKYDKKQQQEILAAKPWTKDHHYFKYCKISAL

Sbjet 1 MAASGSGMAQKTWELANNMQEAQSIDEIYKYDKKQQQEILAAKPWTKDHHYFKYCKISAL 60

Query 61 ALLKMVMHARSGGNLEVMGLMLGKVDGETMIIMDSFALPVEGTETRVNAQAAAYEYMAAY 120

ALLKMVMHARSGGNLEVMGLMLGKVDGETMIIMDSFALPVEGTETRVNAQAAAYEYMAAY

Sbjet 61 ALLKMVMHARSGGNLEVMGLMLGKVDGETMIIMDSFALPVEGTETRVNAQAAAYEYMAAY 120

Query 121 IENAKQVGRLENAIGWYHSHPGYGCWLSGIDVSTQMLNQQFQEPFVAVVIDPTRTISAGK 180 IENAKQVGRLENAIGWYHSHPGYGCWLSGIDVSTQMLNQQFQEPFVAVVIDPTRTISAGK

Sbjet 121 IENAKQVGRLENAIGWYHSHPGYGCWLSGIDVSTQMLNQQFQEPFVAVVIDPTRTISAGK 180

Query 181 VNLGAFRTYPKGYKPPDEGPSEYQTIPLNKIEDFGVHCKQYYALEVSYFKSSLDRKLLEL 240 VNLGAFRTYPKGYKPPDEGPSEYQTIPLNKIEDFGVHCKQYYALEVSYFKSSLDRKLLEL

Sbjct 181 VNLGAFRTYPKGYKPPDEGPSEYQTIPLNKIEDFGVHCKQYYALEVSYFKSSLDRKLLEL 240

Query 241 LWNKYWVNTLSSSSLLTNADYTTGQVFDLSEKLEQSEAQLGRGSFMLGLETHDRKSEDKL 300 LWNKYWVNTLSSSSLLTNADYTTGQVFDLSEKLEQSEAQLGRGSFMLGLETHDRKSEDKL

Sbjet 241 LWNKYWVNTLSSSSLLTNADYTTGQVFDLSEKLEQSEAQLGRGSFMLGLETHDRKSEDKL $30 \odot$

Query 301 AKATRDSCKTTIEAIHGLMSQVIKDKLFNQINIS 334

AKATRDSCKTTIEAIHGLMSQVIKDKLFNQIN++

Sbjet 301 AKATRDSCKTTIEAIHGLMSQVIKDKLFNQINVA 334 


\section{$7 \quad$ Literaturverzeichnis}

Abcam: pQM-NTag/A intron vector (ab1065); http://www.abcam.com/pQM-NTagA-intron-vector-ab1065.html

Almenar-Queralt A, Goldstein LS (2001): Linkers, packages and pathways: new concepts in axonal transport. Curr Opin Neurobiol 11, 550-557

Altschul SF, Gish W, Miller W, Myers EW, Lipman DJ (1990): Basic local alignment search tool. J Mol Biol 215, 403-10

Baas PW, Karabay A, Qiang L (2005): Microtubules cut and run. Trends Cell Biol 15, 518-524

Bech-Otschir D, Kapelari B, Dubiel W: The COP9 Signalosome: Its Possible Role in the Ubiquitin System; in: Protein Degradation vol. 1; hrsg. v. Mayer R, Ciechanover A, Rechsteiner M; Wiley-VCH Verlag, Weinheim 2005, 348-369

Beetz C, Brodhun M, Moutzouris K, Kiehntopf M, Berndt A, Lehnert D, Deufel T, Bastmeyer M, Schickel J (2004): Identification of nuclear localization sequences in spastin (SPG4) using a novel Tetra-GFP reporter system. Biochem Biophys Res Commun 318, 1079-1084

Birnboim HC, Doly J (1979): A rapid alkaline extraction procedure for screening recombinant plasmid DNA. Nucleic Acids Res 푸 1513-1523

Böhm J: Identifizierung und Charakterisierung von putativen Interaktionspartnern des Spastins. Biologische Diplomarbeit Göttingen 2003 
Bounpheng MA, Melnikova IN, Dodds SG, Chen H, Copeland NG, Gilbert DJ, Jenkins NA, Christy BA (2000): Characterization of the mouse JAB1 cDNA and protein. Gene 242, 41- 50

Bruyn RPM, Scheltens F: Hereditary spastic paraparesis (StrümpellLorrain); in: Handbook of clinical neurology, Vol 15: Diseases of the motor system; hrsg. v. de Jong JMBV; Elsevier Science Publishers B. V., Oxford 1991, 301-318

Bürger J, Fonknechten N, Hoeltzenbein M, Neumann L, Bratanoff E, Hazan J, Reis A (2000): Hereditary spastic paraplegia caused by mutations in the SPG4 gene. Eur J Hum Genet $\underline{8}$, 771-776

\section{Burger-Kentischer A, Finkelmeier D, Thiele M, Schmucker J, Geiger G,} Tovar GE, Bernhagen J (2005): Binding of JAB1/CSN5 to MIF is mediated by the MPN domain but is independent of the JAMM motif. FEBS Lett $\underline{579}, 1693-1701$

\section{Charvin D, Cifuentes-Diaz C, Fonknechten N, Joshi V, Hazan J, Melki J,} Betuing S (2003): Mutations of SPG4 are responsible for a loss of function of spastin, an abundant neuronal protein localized in the nucleus. Hum Mol Genet 12, 71-78

Claret FX, Hibi M, Dhut S, Toda T, Karin M (1996): A new group of conserved coactivators that increase the specificity of AP-1 transcription factors. Nature $\underline{383}, 453-457$

\section{Claudiani P, Riano E, Errico A, Andolfi G, Rugarli EI (2005): Spastin} subcellular localization is regulated through usage of different translation start sites and active export from the nucleus. Exp Cell Res $\underline{309}$, 358-369

Clontech: pDsRed2-N1 Vector Information; Clontech 2003

Clontech: pEGFP-C1 Vector Information; Clontech 2002 
Cope GA, Suh GS, Aravind L, Schwarz SE, Zipursky SL, Koonin EV, Deshaies RJ (2002): Role of predicted metalloprotease motif of Jab1/Csn5 in cleavage of Nedd8 from Cul1. Science 298, 608-611

Cormack BP, Valdivia RH, Falkow S (1996): FACS-optimized mutants of the green fluorescent protein (GFP). Gene $\underline{173}$, 33-38

\section{Coutinho P, Barros J, Zemmouri R, Guimaraes J, Alves C, Chorao R,} Lourenco E, Ribeiro P, Loureiro JL, Santos JV et al. (1999): Clinical heterogeneity of autosomal recessive spastic paraplegias: Analysis of 106 patients in 46 families. Arch Neurol 56, 943-949

Errico A, Ballabio A, Rugarli EI (2002): Spastin, the protein mutated in autosomal dominant hereditary spastic paraplegia, is involved in microtubule dynamics. Hum Mol Genet 11, 153-163

Errico A, Claudiani P, D'Addio M, Rugarli EI (2004): Spastin interacts with the centrosomal protein NA14, and is enriched in the spindle pole, the midbody, and the distal axon. Hum Mol Genet $\underline{13}$, 2121-2132

\section{Evans KJ, Gomes ER, Reisenweber SM, Gundersen GG, Lauring BP (2005):} Linking axonal degeneration to microtubule remodeling by Spastinmediated microtubule severing. J Cell Biol 168, 599-606

Feinberg AP, Vogelstein B (1983): A technique for radiolabeling DNA restriction endonuclease fragments to high specific activity. Anal Biochem 132, 6-13

Fink JK: Hereditary spastic paraplegia; in: Emery and Rimoin’s Principles and Practice of medical genetics, 4th edition; hrsg. v. Rimoin DL, Pyeritz RE, Connor JM, Korf BR; Churchill Livingstone, London 2002, 3124-3145 
Fonknechten N, Mavel D, Byrne P, Davoine CS, Cruaud C, Boentsch D, Samson D, Coutinho P, Hutchinson M, McMonagle P et al. (2000): Spectrum of SPG4 mutations in autosomal dominant spastic paraplegia. Hum Mol Genet 9 , 637-644

Frickey T, Lupas AN (2004): Phylogenetic analysis of AAA proteins. J Struct Biol 146, 2-10

Hamel C (2006): Retinitis pigmentosa. Orphanet J Rare Dis $\underline{1}, 40$

Harding AE (1981): Hereditary "pure“ spastic paraplegia: a clinical and genetic study of 22 families. J Neurol Neurosurg Psychiatry 44, 871-883

Harding AE: Hereditary "pure“ spastic paraplegia; in: The hereditary ataxias and related disorders; hrsg. v. Harding AE; Churchill Livingstone, Edinburgh 1984, 174-190

Hazan J, Fonknechten N, Mavel D, Paternotte C, Samson D, Artiguenave F, Davoine CS, Cruaud C, Dürr A, Wincker P et al. (1999): Spastin, a new AAA protein, is altered in the most frequent form of autosomal dominant spastic paraplegia. Nat Genet 23, 296-303

Heckenlively JR: Retinitis Pigmentosa; in: Retinitis Pigmentosa; hrsg. v. Heckenlively JR; Lippincott, Philadelphia 1988, 1-269

Hentati A, Pericak-Vance MA, Hung WY, Belal S, Laing N, Boustany RM, Hentati F, Ben Hamida M, Siddique T (1994): Linkage of 'pure' autosomal recessive familial spastic paraplegia to chromosome 8 markers and evidence of genetic locus heterogeneity. Hum Mol Genet $\underline{3}$, 1263-1267

\section{Hetfeld BK, Helfrich A, Kapelari B, Scheel H, Hofmann K, Guterman A et} al. (2005): The zinc finger of the CSN-associated deubiquitinating enzyme USP15 is essential to rescue the E3 ligase Rbx1. Curr Biol 15, 1217-1221 
Hofmann K, Bucher P (1998): The PCI domain: a common theme in three multiprotein complexes. Trends Biochem Sci. 23, 204- 5

Holzbaur EL (2004): Motor neurons rely on motor proteins. Trends Cell Biol 14, 233-240

Klebe S, Durr A, Bouslam N, Grid D, Paternotte C, Depienne C, Hanein S, Bouhouche A, Elleuch N, Azzedine $\mathrm{H}$ et al. (2007): Spastic paraplegia 5: Locus refinement, candidate gene analysis and clinical description. Am J Med Genet B Neuropsychiatr Genet 144B, 854-861

Kogan SC, Doherty M, Gitschier J (1987): An improved method for prenatal diagnosis of genetic diseases by analysis of amplified DNA sequences. New Engl J Med 317, 985-990

Kwok SF, Solano R, Tsuge T, Chamovitz DA, Ecker JR, Matsui M, Deng XW (1998): Arabidopsis homologs of a c-Jun coactivator are present both in monomeric form and in the COP9 complex, and their abundance is differentially affected by the pleiotropic cop/det/fus mutations. Plant Cell $\underline{10}$, $1779-1790$

Laemmli UK, Beguin F, Gujer-Kellenberger G (1970): A factor preventing the major head protein of bacteriophage T4 from random aggregation. J Mol Biol $\underline{47}, 69-85$

Lindsey P, Lusher M, McDermott C, White K, Reid E, Rubinsztein D, Bashir R, Hazan J, Shaw P, Bushby K (2000): Mutation analysis of the spastin gene (SPG4) in patients with hereditary spastic paraplegia. J Med Genet 37, 759-765

Lyapina S, Cope G, Shevchenko A, Serino G, Tsuge T, Zhou C, Wolf DA, Wei N, Shevchenko A, Deshaies RJ (2001): Promotion of NEDD-CUL1 conjugate cleavage by COP9 signalosome. Science 292, 1382-1385 


\section{McDermott CJ, Grierson AJ, Wood JD, Bingley M, Wharton SB, Bushby} KM, Shaw PJ (2003): Hereditary spastic paraparesis: disrupted intracellular transport associated with spastin mutation. Ann Neurol $\underline{54}$, 748-759

Meindl A, Dry K, Herrmann K, Manson F, Ciccodicola A, Edgar A, Carvalho MR, Achatz H, Hellebrand H, Lennon A et al. (1996): A gene (RPGR) with homology to the RCC1 guanine nucleotide exchange factor is mutated in X-linked retinitis pigmentosa (RP3). Nat Genet 13, 35-42

\section{Muglia M, Criscuolo C, Magariello A, De Michele G, Scarano V, D'Adamo P,} Ambrosio G, Gabriele AL, Patitucci A, Mazzei R et al. (2004): Narrowing of the critical region in autosomal recessive spastic paraplegia linked to the SPG5 locus. Neurogenetics $\underline{5}$, 49-54

Mullis KB, Faloona FA (1987): Specific synthesis of DNA in vitro via a polymerase-catalyzed chain reaction. Methods Enzymol 155, 335-350

Mundt KE, Liu C, Carr AM (2002): Deletion mutants in COP9/signalosome subunits in fission yeast Schizosaccharomyces pombe display distinct phenotypes. Mol Biol Cell 13, 493- 502

Nogales E (2000): Structural insights into microtubule function. Annu Rev Biochem $\underline{69}$, 277-302

Patel S, Latterich M (1998): AAA team: related ATPases with diverse functions. Trends. Cell Biol $\underline{8}, 65-71$

Paulus W, Engel W, Sauter S, Neesen J (2002): Hereditäre spastische Paraplegie. Dtsch Arztebl 99, A434-440

Peth A, Boettcher JP, Dubiel W (2007): Ubiquitin-dependent Proteolysis of the Microtubule End-binding Protein 1, EB1, Is Controlled by the COP9 Signalosome: Possible Consequences for Microtubule Filament Stability. J Mol Biol 368, 550-563 
Petroski MD, Deshaies RJ (2005): Function and regulation of cullin-RING ubiquitin ligases. Nat Rev Mol Cell Biol $\underline{6}$, 9-20

Portera-Cailliau C, Sung CH, Nathans J, Adler R (1994): Apoptotic photoreceptor cell death in mouse models of retinitis pigmentosa. Proc Natl

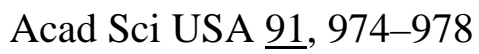

Proukakis C, Hart P, Cornish A, Warner T, Crosby A (2002): Three novel spastin (SPG4) mutations in families with autosomal dominant hereditary spastic paraplegia. J Neurol Sci 201, 65

Reid E (2003): Science in motion: common molecular pathological themes emerge in the hereditary spastic paraplegias. J Med Genet 40, 81-86

Reid E, Connell J, Edwards TL, Duley S, Brown SE, Christopher, Sanderson CM (2005): The hereditary spastic paraplegia protein spastin interacts with the ESCRT-III complex-associated endosomal protein CHMP1B. Hum Mol Genet $\underline{14}, 19-38$

\section{Roepman R, Bernoud-Hubac N, Schick DE, Maugeri A, Berger W, Ropers} HH, Cremers FP, Ferreira PA (2000): The retinitis pigmentosa GTPase regulator (RPGR) interacts with novel transport-like proteins in the outer segments of rod photoreceptors. Hum Mol Genet $\underline{9}$, 2095-2105

Roll-Mecak A, Vale RD (2005): The Drosophila homologue of the hereditary spastic paraplegia protein, spastin, severs and disassembles microtubules. Curr Biol 15, 650-655

Salinas S, Carazo-Salas RE, Proukakis C, Schiavo G, Warner TT (2007): Spastin and microtubules: Functions in health and disease. J Neurosci Res 85, 2778-2782

Sanger F, Nicklen S, Coulsen AR (1977): DNA sequencing with chainterminating inhibitors. Proc Natl Acad Sci USA 74, 5463-5467 
Sauter S, Miterski B, Klimpe S, Bonsch D, Schols L, Visbeck A, Papke T, Hopf HC, Engel W, Deufel T, Epplen JT, Neesen J (2002): Mutation analysis of the spastin gene (SPG4) in patients in Germany with autosomal dominant hereditary spastic paraplegia. Hum Mutat 20, 127-132

Schaefer L, Beermann ML, Miller JB (1999): Coding sequence, genomic organization, chromosomal localization, and expression pattern of the signalosome component Cops2: the mouse homologue of Drosophila alien. Genomics 트, 310- 16

Schwechheimer C, Serino G, Callis J, Crosby WL, Lyapina S, Deshaies RJ, Gray WM , Estelle M, Deng XW (2001): Interactions of the COP9 signalosome with the E3 ubiquitin ligase SCFTIRI in mediating auxin response. Science 292, 1379-1382

Seeger M, Kraft R, Ferrell K, Bech-Otschir D, Dumdey R, Schade R, Gordon C, Naumann M, Dubiel W (1998): A novel protein complex involved in signal transduction possessing similarities to 26S proteasome subunits. FASEB J 12, 469- 78

Skre H (1974): Hereditary spastic paraplegia in Western Norway. Clin Genet $\underline{6}$, 165-183

Staub JM, Wei N, Deng XW (1996): Evidence for FUS6 as a component of the nuclear-localized COP9 complex in Arabidopsis. Plant Cell 모, 2047- 2056

Strümpell A (1880): Beiträge zur Pathologie des Rückenmarks. Arch Psychiatr Nervenkr $\underline{10}$, 676-717

\section{Svenson IK, Ashley-Koch AE, Gaskell PC, Riney TJ, Cumming WJ,} Kingston HM, Hogan EL, Boustany RM, Vance JM, Nance MA et al. (2001): Identification and expression analysis of spastin gene mutations in hereditary spastic paraplegia. Am J Hum Genet 68,1077-85 
Tallaksen CM, Durr A, Brice A (2001): Recent advances in hereditary spastic paraplegia. Curr Opin Neurol 14, 457-63

Tomoda K, Kubota Y, Arata Y, Mori S, Maeda M, Tanaka T, Yoshida M, Yoneda-Kato N, Kato JY (2002): The cytoplasmic shuttling and subsequent degradation of p27Kip1 mediated by Jab1/CSN5 and the COP9 signalosome complex. J Biol Chem 277, 2302- 2310

Trotta N, Orso G, Rossetto MG, Daga A, Broadie K (2004): The hereditary spastic paraplegia gene, spastin, regulates microtubule stability to modulate synaptic structure and function. Curr Biol 14, 1135-1147

Uhle S, Medalia O, Waldron R, Dumdey R, Henklein P, Bech-Otschir D, Huang X, Berse M, Sperling J, Schade R et al. (2003): Protein kinase CK2 and protein kinase D are associated with the COP9 signalosome. EMBO J 22, 1302-1312

Vale RD (2000): AAA proteins. Lords of the ring. J Cell Biol 150, F13-19

Wee S, Geyer RK, Toda T, Wolf DA (2005): CSN facilitates Cullin-RING ubiquitin ligase function by counteracting autocatalytic adapter instability. Nat Cell Biol 7, 387-391

Wei N, Deng XW (1992): COP9: a new genetic locus involved in light-regulated development and gene expression in Arabidopsis. Plant Cell 4, 1507- 1518

Wei N, Deng XW (2003): The Cop9 Signalosome. Annual Review of Cell and Dev Biol 19, 261-286

Werdelin L (1986): Hereditary ataxias. Occurrence and clinical features. Acta Neurol Scand $\underline{73}$ (Suppl. 106), 124 
Wharton SB, McDermott CJ, Grierson AJ, Wood JD, Gelsthorpe C, Ince PG, Shaw PJ (2003): The cellular and molecular pathology of the motor system in hereditary spastic paraparesis due to mutation of the spastin gene. $\mathrm{J}$ Neuropathol Exp Neurol 62, 1166-1177

Wilkinson PA, Crosby AH, Turner C, Patel H, Wood NW, Schapira AH, Warner TT (2003): A clinical and genetic study of SPG5A linked autosomal recessive hereditary spastic paraplegia. Neurology $\underline{61}$, 235-238

Willems AR, Schwab M, Tyers M (2004): A hitchhiker's guide to the cullin ubiquitin ligases: SCF and its kin. Biochim Biophys Acta 1695, 133-170

Xiao-Chun Zhang, Jian Chen, Chun-Hui Su, Heng-Yin Yang, Mong-Hong Lee (2007): Roles for CSN5 in control of p53/MDM2 activities. J Cell Biochem 103, 1219-1230

Yang X, Menon S, Lykke-Andersen K, Tsuge T, Di X, Wang X, RodriguezSuarez RJ, Zhang H, Wei N (2002): The COP9 signalosome inhibits p27(kip1) degradation and impedes G1-S phase progression via deneddylation of SCF Cul1. Curr Biol 12, 667- 72

Zhao X, Alvarado D, Rainier S, Lemons R, Hedera P, Weber CH, Tukel T, Apak M, Heiman-Patterson T, Ming $L$ et al. (2001): Mutations in a newly identified GTPase cause autosomal dominant hereditary spastic paraparesis. Nat Genet 29, 326-31 


\section{Danksagung}

Mein Dank gilt Herrn Prof. Dr. W. Engel für die Überlassung des Themas sowie die Unterstützung durch finanzielle und räumliche Ressourcen im Institut für Humangenetik. Sein immer währendes Interesse am Fortgang der Arbeit mit Diskussion, Anregungen und Korrekturen haben das Gelingen dieser Arbeit ermöglicht.

Mein besonderer Dank gilt Herrn PD Dr. J. Neesen für die Überlassung des Themas und die Aufnahme in seine Arbeitsgruppe. Die freundschaftliche Atmosphäre, Geduld und Nachsichtigkeit mit einem jungen Medizinstudenten, der viel zu lernen hatte, haben diese Arbeit erst ermöglicht. Ein großer Dank gilt weiterhin für das stets vorhandene Interesse über kleine und große zeitliche und räumliche Distanzen hinweg, für die Diskussionsbereitschaft und die wiederholten Korrekturen während des Zusammenschreibens. Ich bedanke mich für die beste Betreuung, die man sich wünschen kann, während meiner gesamten Zeit im Labor und insbesondere auch über diese hinaus!

Auch bei allen Mitarbeitern des Labors 114 und des Instituts für Humangenetik möchte ich mich bedanken. Ich danke hier insbesondere Sajid Rashid für seine immer gewährte Hilfe und Unterstützung sowie Nadine Dörwald, ohne deren Hilfe ein Fortgang der Arbeit ebenfalls nicht möglich gewesen wäre. 


\section{Lebenslauf}

Am 17.09.1979 wurde ich in Hildesheim geboren.

Im Sommer 1986 wurde ich in die Grundschule Söhlde eingeschult. Von 1990 bis 1992 besuchte ich die Orientierungsstufe Söhlde. Dem folgte von 1992 bis 1999 das Scharnhorstgymnasium Hildesheim. Dort beendete ich meine Schullaufbahn mit der allgemeinen Hochschulreife.

Im Sommer 1999 schloss sich bis Mai 2000 der Wehrersatzdienst am Städtischen Krankenhaus Hildesheim an.

Im Oktober 2000 nahm ich das Humanmedizinstudium an der Georg-AugustUniversität Göttingen auf. Nach der ärztlichen Vorprüfung am 13.09.2002, dem ersten Abschnitt der ärztlichen Prüfung am 28.08.2003 und dem zweiten Abschnitt der ärztlichen Prüfung am 24.03.2006 folgte das Praktische Jahr. Beginnend an der Universitätsmedizin Göttingen am 17.04.2006 beendete ich dieses am Good Health Wanganui Hospital, Neuseeland am 18.03.2007. Mit Ablegen des dritten Abschnitts der ärztlichen Prüfung am 16.10.2007 schloss ich mein Studium ab. Am 13.12.2007 wurde mir die Approbation als Arzt erteilt.

Zum Zeitpunkt der Abgabe dieser Dissertation bin ich im zweiten Assistenzjahr in der Abteilung Diagnostische Radiologie an der Universitätsmedizin Göttingen beschäftigt. 